\title{
Could Cll Approach be a Remedy for Tripoli Secondary Students Speaking Skills?
}

\author{
Dr. Mona Tahseldar* \\ Assocate Professor in English Education, lebanon
}

*Corresponding Author: Mona Tahseldar, Assocate Professor in English Education, lebanon

\begin{abstract}
Students`speaking English anxiety in EFL classes puts the teachers on top of their readiness to assist learners achieve better performance when speaking the foreign language. The present study investigated the impact of Community Language Learning (CLL) approach as a remedy for Tripoli private and public secondary school students who suffer from speaking anxiety in EFL classes. Data was collected from the quantitative and qualitative method results, through pre post questionnaire to answer the study questions. A total of 117 participants (teachers and students), 115 of grade ten students (males and females) ranging from beginner to intermediate level of English proficiency, and aged between 15-16 years old, along with two highly experienced and licensed EFL female instructors. The findings suggested that language anxiety may originate from the learners themselves, teachers or the learning environment which leads to students language learning difficulties, fear of making mistakes and losing their identity. The investigation broadened the insight into the issue of language anxiety in the Lebanese classrooms, and helped not only students but also teachers in alleviating learners language anxiety, promoting motivation to speak English and increase Language acquisition. The findings of this study proved by statistics that CLL is a beneficial teaching approach to enhance learners' oral communication abilities in the target language.
\end{abstract}

Keywords: language anxiety; speaking anxiety; communicative language learning; speaking skills;

\section{INTRODUCTION}

English has become a must for communication now a days, it is the language of globalization that embraces a lot of essential terms in our daily life. Communication using foreign language to many researchers such as Efrizal (2012), and A.P. Gilakjani (2016), is a very complex process to students. In teaching a foreign language, Al Hosny (2015) found that the oral communication skills is highly recommended especially that the $21^{\text {st }}$ century requires good abilities of speaking English fluently. Moreover, Leong (2017) identified success in EFL speaking as the ability to perform a conversation in the language, and he considered that the main aim behind teaching English language is to supply learners with the right oral abilities that help them speak the English language effectively. However, Teaching EFL in general and the speaking skill in particular are considered a challenge for both teachers and students in both private and public sectors, which requires a special attention from all educators. Hence, developing students`English speaking is an essential task in today's EFL curriculum objectives. Although students are able to manage with almost all school subjects we find them fail to make it when it comes to using the foreign language in communicating with others and feel mental blocked, stressed and anxiety, whenever they wanted to express using this language which hinder their language learning and performance abilities (Horwitz et al., 1986).

Many educators attributed students`stress, blockage and hesitation when using foreign language to express themselves to anxiety, and teachers following the traditional methods in teaching the EFL speaking skill. Horwitz, Horwitz \& Cope (1986) defined language anxiety as a distinct complete of self-perception, beliefs, feelings, and behaviors related to classroom language learning arising from the uniqueness of the language learning process. In the same sense, Dewaele (2007) warned of the consequences of students` failure to overcome their anxiety when using the foreign language before school graduation, or else, they will end up not using the language again. In most cases, anxiety is often reported to be an important cause for decreased learning speaking motivation, interference with the learning process, and poor performance, Sparks and Ganschow, (2007). Moreover, Weiten and McCann, (2007) revealed that understanding students' anxiety means helping those who worry about 
their performance effectiveness and dwell in their stress, in a way that they turn that anxiety into a positive motivation for further learning. They added that it is the teachers` responsibility to avoid students` speaking foreign language anxiety and find the suitable learning environment. Savignon, S. (2003) highlighted the importance of the Communicative Language Learning (CLL) approach, derived from the Counseling Learning Approach developed by Charles A. Curran and Diana LarsenFreeman (2000), in reducing students` anxiety and motivating them to speak English.

\subsection{Statement of the Problem}

As an experienced English foreign language teacher, it was obvious that our students in all levels suffer of being considered as low foreign language achievers. Thus, the problem is common among learners from beginning to higher levels in both sectors public and private. More precisely, EFL teachers could realize that many students are considered low achievers in all English language skills but the worst of all is the speaking abilities. Richards and Rodgers (2001) have mentioned that teaching EFL skills is usually accomplished through traditional methods, where the speaking skill is almost ignored which contradicts the most updated EFL teaching methods. Ur (2000) has prioritized speaking among all the EFL skills for an effective foreign language communication. Consequently, anxiety experienced in communicating using English is influencing students' adaptation to the target language and ultimately the achievement of their EFL education goals specifically their oral skill.

Although, most anxiety symptoms are easy to be realized through students` behavior, we find that most teachers in the private and public sectors kept using the traditional methods ignoring the consequences of students `anxiety in language learning and its effects on their fluency, accuracy and pronunciation. As anxiety is a complex psychological phenomenon influenced by many different factors and had many effects that should be solved, Kota Ohata (2005) suggested the updated Communicative Language Learning approach to resolve it. Consequently, the present study was concerned about revealing the reasons behind students` English speaking anxiety and helping them overcome this issue through examining the effects of CLL on students` speaking achievement as well as the differences occurred between public and private students' achievement before and after implementing CLL approach in EFL speaking classes.

\subsection{Rationale}

Twenty first century can be described as the century of progress and improvement in EFL education, but unfortunately, differences still occur in the Lebanese schools between students ' language skills in the private sector and those in the public one, and the most realized weakness is in the speaking skill. All previous researches conducted in our area were descriptive in nature and statistically demonstrated the existence of foreign language anxiety. Thus, the motif behind generating the idea of establishing the CLL method in our school classrooms is to reduce language anxiety for a better oral performance. In spite of the subject stiffness, the CLL approach was selected due to its distinctiveness in terms of its strategies that involved G 10 English students all over their course period that helped comparing the differences in the results between public and private schools. Thus, the adopted technique in this research was based on students` weaknesses and inability to speak English fluently, anxiety and the differences occurred in oral performance between the public and private sector students.

\subsection{Research Questions}

In order to examine the impact of this study implemented CLL method, it was necessary to answer the following research questions:

1) What are the anxiety factors that affect the students while expressing themselves using the foreign language?

2) What is the difference between public sector students and private sector students in acquiring the speaking skill of the foreign language, with respect to grades and anxiety level?

3) What are the effects of implementing CLL method in speaking classes on students' EFL speaking achievement in both sectors?

4) How can this approach help in reducing the level of anxiety?

\section{Significance OF The STUdy}

This investigation broadened the insight into the issue of language anxiety in EFL Lebanese secondary classrooms that could be a support not only for students but also for teachers to reduce 
students`speaking anxiety, promote motivation to learn English and increase language acquisition in Tripoli Secondary Schools. The reality that stands behind Numaya' assumption is the existence of close relationship between language anxiety and speaking. According to J. Richards (2006), this requires a communicative language learning approach that helps students to reduce their language anxiety, and support teachers who are suffering from students` poor speaking skills. He presented the solution through transcripts, texts, dialogues, conversations, cards games, and furthermore examination of a grammar point, working on pronunciation, creating new sentences with words from the transcripts, and ending the course with reflection on the experience.

\section{REVIEW OF LITERATURE}

Anxiety in itself has many factors, facets and various implications in all fields, which are going to serve as introductory to this study. Nonetheless, the endeavor here is to focus on the relation between speaking skill and anxiety.

Many definitions of learning and language anxiety were presented, such as Freud (1924) cited in Spielberger (1972), Leary (1982), Horwitz, et al. (1986), Schwarzer (2013), who agreed that anxiety is a subjective feeling of tension, apprehension, nervousness, and worry associated with an arousal of the autonomic nervous uneasy feeling due to something threatening which leads to a boring, anxious, and stable class. Accordingly, Horwitz et al., (1986) stated that anxiety shares general symptoms such as panic, fear, not being able to stay calm and still, playing with hair or clothes, cold, sweaty, numb or tingling hands, shortness of breath, heart palpitations, lack of eye contact, excessive perspiration, and dry mouth that differ from one person to another. Similarly, Tercan, G. (2015) Horwitz \& Horwitz and Cope (1986), and Young (1991) MacIntyre (1998) classified language anxiety as the apprehension experienced in a situation that requires the use of a second language and the individual is not fully proficient. The majority of the conducted studies in language anxiety such as Horwitz \& Cope (1986), Gardner (1991), Burstein (1989), Sparks MacIntyre (1992) have found that foreign language anxiety has an important impact on students' achievement or performance. Most of the studies found that there are negative correlations between anxiety and achievement, such as Aida (1994), Batumlu \& Erden (2007), Chen \& Chang, (2004), Chiang (2012), El khafaifi (2005), Noor mohamadi (2009) Şener (2015), Park \& French (2013), Subaşı (2010) concluded that there is a positive correlation between anxiety and achievement. Nevertheless; Piechurska-Kuciel, (2008) claimed that all language students at all stages of foreign language acquisition experience a certain degree of language anxiety. In the same sense, for many researchers like Gregersen, (2006) and Crookall \& Oxford, (1991) students` moderate anxiety can be stimulating and helpful because it motivates them to undertake the new task, which promotes learning. Researches in the field of EFL linguistics have showed three types on anxiety: trait anxiety that has been identified by Woodrow (2006), as a relatively stable personality characteristic where the trait anxious person would become anxious in different kinds of situations at any time, while the state anxiety and situational anxiety, as defined by (MacIntyre\& Gardner, 1991, Brown, 2011) (Speilberger, 1983, cited in Tanveer, 2007, p.4) Luo (2014), is momentary, for it is only the apprehension felt at a particular moment in time, which means it is a temporary unpleasant emotional state. Hence, language anxiety is a subcategory of situation-specific anxiety (Elkhafaifi, 2005; Horwitz, 2001).

Furthermore, foreign language anxiety has three components: Communication apprehension, test anxiety, and fear of negative evaluation. Many authors like Horwitz et al. (1986) (McCroskey, 1997, as cited in Horwitz et al., 1986) (X Zhang, 2003) considered that Communication apprehension is the individual's level of fear or anxiety associated with either real or anticipated communication with another person or group of persons, which usually leads students to feel uncomfortable during speaking classes, and unwilling to communicate as well as less risk taking that in turn hinders successful performance and diminish the communication skills development. Accordingly, the second type is test anxiety which many authors (Horwitz et al., 1986) ) (Liu\& Jackson, (2008) (Zhiping, 2013) (Thompson \& Lee, 2014) defined it as a type of performance anxiety stemming from a fear of failure where students put unrealistic outcomes and feel that anything less than a perfect performance is a failure, so they demand more of themselves than they are capable of which sometimes can be positive when controlled. Moreover, the mentioned researchers agreed that test-anxious students have difficulties in learning and retrieving information during tests, which leads to poor performance in tests, low self-esteem, low academic scores, passiveness to education, and even school refusal. Concerning the fear of negative evaluation, the third type of language anxiety, many scholars, 
researchers and authors agreed that it involves apprehension about others' evaluations, avoidance of evaluative situations, and the expectation that others would evaluate oneself negatively. For instance, Hammad \& Abu Ghali, (2015) Gregersen \& Horwitz,( 2002) and Zhang (2013) Found that learners here rarely initiate conversations and they interact minimally in classrooms and realized that the students' fear of making mistakes and apprehension about others' evaluation could be the key sources of English speaking anxiety classes.

Due to the high effect of English language learning anxiety on learners, many researches have been conducted to collect data about the factors, and causes behind this type of anxiety, so they could find solutions for language anxiety. One area of research for language anxiety factors examined the situational variables where many authors revealed (Jackson, 2002; Speilmann and Radnofsky, 2001; Andrade \& Williams, 2009) that it is concerned with the course activities, course level, organization, and the instructor behavior and the learner variables. Accordingly, Piechurska (2008) indicated that the true factors, after the communication apprehension, test anxiety and fear of negative evaluation are personal and interpersonal anxieties resulted from the learners' beliefs about language learning, the instructor' beliefs about language teaching, the interaction between learner and instructor, the classroom procedure and the language testing. Accordingly, Cubukcu (2008) noted that learners with low self-efficacy have a higher level of anxiety than learners with high self-efficacy (Cubukcu, 2008). Concerning this issue, many more factors were discussed in literature; Awan, Azher, Anwar and Naz (2010) Synder, (2011) pointed out that worries about grammatical mistakes, pronunciation and being unable to respond quickly also cause high level on anxiety. Other researchers pointed out that strict and formal native language classroom environment, socio-cultural reasons and the traditional learning system appeared also to be blamed for being significant causes of the learners' foreign language anxiety Ohata, (2005), Khan and Zafar (2010).

Many other relevant studies were conducted like Alrabai (2017) who conducted a study in Saudi Arabia to investigate the factors of Saudi learners' anxiety using the Foreign Language Anxiety Scale (FLCAS) for three years. As a result, he found that the main cause of anxiety is students lack of preparation before the English class. Moreover, Fang-Peng and Dong (2010) carried out a survey with 82 Chinese college students and revealed that the learner's attention to intonation and pronunciation, motivation, and the interference of the mother tongue the main factors of causing students learning anxiety. Adding to these studies, Subaci (2010) investigated the main sources of Turkish EFL students' anxiety in oral practice at Anadolu University, Education Faculty, using FLCA scale and fifty five items multiple choice surveys. The analysis indicated a significant negative relationship between anxiety and self rating and a positive correlation between individual's fear of negative evaluation and his or her anxiety level. Parental issues had a part in investigating the factors behind language learning anxiety in which Burstein, M. Ginsburg, G.S. \&Tein J. (2010) conducted a study on ninety seven participants of parents and their children to test the interactive effects of parent anxiety on child symptoms where the results showed a high and significant correlation with parents' child symptom variables. Lately, a study conducted by Rafada \& Madini (2017), investigated the main factors of Foreign Language Speaking anxiety (FLSA) among female university students in Saudi Arabia that revealed many factors may cause anxiety such as the lack of vocabulary, teacher's role, fear of peers' comments, test anxiety, weakness of the educational system in the Saudi Arabia, and the classroom atmosphere.

In contrast to all the previous studies, Scovel (1978) claimed that anxiety can have a positive effect since it motivates learners to study harder and make more efforts to get a better oral performance of which G. Özütürk (2013) considered it a controversial issue as this emotional state is not yet proved to be really anxiety or not. Through all what was mentioned so far concerning the factors behind language learning anxiety were classified by Tallon (2009) in three categories; Learner's characteristics, Teacher's characteristics and Classroom's characteristics.

\subsection{Language Anxiety And The Speaking Skill}

Speaking is one of the most significant skills in language learning. Frantze\& Magnan, (2005) and Wilson (2006) found that foreign language anxiety reactions include "inability to reproduce the intonation and rhythm of the language, 'freezing up' when called on to perform, and forgetting words or phrases just learned or simply refusing to speak or remaining silent. Similarly, to Melough ( 2013) and Mohammed \& Wahid (2009), speaking anxiety is one of the most important affective variables 
that influences foreign language learning, because it has a detrimental effect on the students' oral performance of English and a negative influence on the students' learning atmosphere and their achievement. However, diversity of results related to the relationship between anxiety and foreign language learning were noticed in literature which could be explained through Philip (cited in Shams, 2000, p5): "a comparison of the experimental research examining the relationship between anxiety and second language learning is, to a degree, perplexing, presenting some conflicting evidence and illustrating that anxiety is a complex, multi-faceted construct." With this complexity and controversy, it is likely that foreign language anxiety has been and will continue to be a key area of research interest, while the teachers` duty is to devise applicable strategies to help students reduce their anxiety.

Many suggestions were offered to reduce language anxiety in the classroom and they are all mostly under two bold parts: student-centered methods and teacher-centered ones. According to Kondo \& Ying- Ling (2004, p.259), if students realize the causes of their anxiety, they may invest effort to reduce it. Also Khan and Zafar (2010), suggested that language anxiety arousal at the early stages of processing will create cognitive deficits that can be overcome when students re-learn the missing material. Efforts to re-input the missing information or have improperly processed should be accompanied throughout the speaking skill. Whereas Kondo (2004) identified 70 basic tactics and put them into five strategy categories: preparation, relaxation, positive thinking, peer seeking, and resignation. Oya, Manalo and Greenwood (2004), (Tanveer, 2007) found that teachers' expectations about the oral performance of their students should be adjusted with respect to their personality characteristics, and anxiety provoking situation in which students are required to speak (khan \&Zafar, 2010), Ansari (2015), young, et al., (1992), Von Worde (2003), Suwantarathip and Wichadee (2010), Johnson (2005), and $\mathrm{Na}$ (2007).

Along with many suggested strategies, to (Nomass, 2013), Juana \&Palak (2011), Herreid\& Schiller (2013) using technology is one of the $21^{\text {st }}$ century aspects that most of the students like nowadays to reduce language anxiety.

Over and above, since this study focuses on the implementation of the community language learning approach that is recognized as a method of language teaching, and used to reduce language anxiety, it is necessary to give some background literature about it.

\subsection{Community Language Learning Approach}

The CLL approach was developed by Charles Arthur Curran, a Jesuit priest, professor of psychology at Loyola University Chicago and counseling specialist. He derived his ideas from "Counseling learning", a humanistic concept created by Carl Rogers in the 1950s. This method draws on the counseling metaphor, and refers to the teacher and learner as a counselor and a client. According to Curran, a counselor helps a client understand his or her own problems better to solve them. Thus, the CLL to Richards and Rogers (2011) is suitable for those who are interested in an interactive and more communicative approach, so it can be considered as an alternative to the traditional methods. The literature of English language teaching showed that CLL has been adopted in the EFL contexts since the last quarter of the twentieth century, when CLL was at its peak level. Despite the fact that CLL has had its presence in EFL classrooms for more than three decades, its effectiveness and harmonious with EFL classroom settings remained challenging for researchers and practitioners in the field. According to Butler (2011), CLL became the center of attention among general English language educators conforming to Ho's (2002) of EFL status in 15 countries in East Asia. Similarly, Lightbown and Spada (2013) have seen CLL as an approach of teaching which emphasizes the communication of meanings in interaction instead of the practice of grammatical forms in isolation.

Therefore, the CLL approach aimed to provide students with opportunities and strategies to build up their communicative skills. The increasing popularity and successful practice of CLT in EFL classrooms led to a reform in many curricula around the world and had included the community language learning as a central constituent of it. For example, a national CLT-based syllabus was introduced in China, Japan, and North Korea in 1992, 1997, and 1999 (Butler, 2011). As well, a number of research studies have been conducted to investigate the CLT and examine the suitability and possible challenges in the implementation of this communicative approach in EFL contexts (Anderson, 1993; Chang \& Goswarni (2011); Chung \& Huang, (2009); Hu, (2002); Yu, (2001). For example, Wu (2010) noted that English Education in Taiwan has recently moved from grammar- 
focused reading methods to more communication-oriented strategies. $\mathrm{He}$ addressed this problem through the use of communicative language teaching/learning (CLL/CLT). He noted that this approach puts focus on students with the role of the teacher as an advisor, facilitator, and cocommunicator. This communication between the teacher and students allows students to talk freely in English. Moreover, Rao (2002) examined Chinese students' perception of communicative and noncommunicative activities in EFL classrooms and mentioned activities like games, roleplays, simulations, and problem-solving tasks as communicative activities.

Sato and Kleinsasser (1999) referred to role-play, games, survey, group work, and simulations as communicative activities. For Corbett (2003), activities that involve learners in information gap or information transfer tasks are prototypal examples of communicative activities. In a recent study by Chang (2014) that explored the effect of CLT on 163 nursing students` learning motivation in Taiwan, the results revealed that CLT instruction has a positive effect on students' learning motivation. In a similar study, Razmjoo \& Riazi, (2006) investigated the Iranian high school and institute teachers' attitudes toward CLL, the data indicated a positive attitude towards CLL among all teachers who strongly sustain the use of CLL principles in their classes.

Finally, several other studies indicated the favorable and welcoming attitudes of using CLL approach in classroom by teachers and learners (Al-Mekhlafi\& Ramani, 2011; Chang, 2011; Christ \&Makarani, 2009; Karavas-Doukas, 1996; Lashgari1, Jamali, \&Yousofi, 2014; Saricoban\& Tilfarlioglu, 1999; Tsai \& Lee, 2007; Wang, 2000; Asassfeh, Khwaileh, Al-Shaboul, \&Alshboul, 2012, Chung and Huang, 2009; Ngoc \& Iwashita, 2012).

\section{RESEARCH METHODOLOGY}

The approach herein is experimental, quantitative, and statistical since it depends on numerical data to diagnose, describe and answer the study questions. It is possible to resort now to the blending theory and to use the required strategies from different approaches in order to tackle the problem of the secondary students`EFL speaking anxiety in Tripoli Lebanon and the gap between the public and private high schools` language achievement. This was achieved by supporting students overcome their anxiety in English, and the selected methodology CLL that helped in improving students' oral performance and pinpointed to the desired enhancement of students' English competence.

\subsection{Participants}

Being an Empirical research, it is necessary to ensure the cooperation of several population samples. Therefore, the research involved 117 grade 10 students distributed on four classes consisting of 26-32 students in each. The participants are EFL learners belonging to two coeducation schools (one public and the other is private) aged between 15 and 16 years old and shared the same intermediate level of English proficiency. For more details, a number of 64 G10 students were considered as a control group, divided equally between the private and public school. The experimental group, involved 53 students from two G10 classes from the assigned private (26 students) and public (27students) secondary schools. At the end of the year, the number of the control group students decreased to 47 due to dropping out from school (23 Public students $\backslash 24$ Private students). The control group was taught according to the traditional method, while the experimental group was taught using the CLL approach in teaching English speaking skill in both sectors. Worth to be mentioned here that for the purpose of the study, and for equal representation, the researcher was aware to use an equal number of foreign language students in both high schools, and all of the participants were recruited through the cooperation and consent of the schools' administrators, teachers, and students.

Table1. Pre Public and Private Groups

\begin{tabular}{|c|c|c|c|c|}
\hline \multirow[t]{3}{*}{ Group } & \multicolumn{4}{|c|}{ School } \\
\hline & \multicolumn{2}{|c|}{ public } & \multicolumn{2}{|c|}{ private } \\
\hline & $\mathrm{N}$ & $\%$ & $\mathrm{~N}$ & $\%$ \\
\hline Experimental & 26 & $44.8 \%$ & 27 & $45.8 \%$ \\
\hline Control & 32 & $55.2 \%$ & 32 & $54.2 \%$ \\
\hline Total & 58 & $100.0 \%$ & 59 & $100.0 \%$ \\
\hline
\end{tabular}


Table2. Post Public and Private Groups

\begin{tabular}{|l|l|l|l|l|}
\hline \multirow{2}{*}{ Group } & \multicolumn{4}{|l|}{ School } \\
\cline { 2 - 5 } & public & private \\
\cline { 2 - 5 } & $\mathrm{N}$ & $53.1 \%$ & $\mathrm{~N}$ & $\%$ \\
\hline Experimental & 26 & $46.9 \%$ & 27 & $52.9 \%$ \\
\hline Control & 23 & $100.0 \%$ & 24 & $47.1 \%$ \\
\hline Total & 49 & 51 & $100.0 \%$ \\
\hline
\end{tabular}

Table 1 showed that the number of private G10 participants who sat for the pre questionnaire was 59 students; (27 experimental \32 control group), while the public G10 participants were 58; (26 experimental $\backslash 32$ control). Similarly, table 2 showed that the number of G 10 participants who sat for the post questionnaire in both sectors and groups has decreased to become 26 public experimental participants and 23 public control participants, while the number of private sector participants has dropped to become 51 participants; 27 for the experimental group and 24 for the control group. Thus, the number of dropped students was 8 private and 9 public students respectively.

\subsection{Instrumentation}

To achieve the study objectives, The Foreign Language Classroom Anxiety Scale (FLACS) was used in collecting the required data. It was used as pre-test and a post-test instrument to measure students' anxiety level while speaking and communicating in English before and after implementing the CLL approach. The design of this study included a self-reporting measure based on an analysis of potential sources of anxiety adopted from the (FLCAS) Horwitz, Horwitz and Cope (1986). Checking and ensuring the reliability and validity of the FLCAS was through literature. Many researchers like Sara Atef- Vahid (2011), Rola Lababidi (2015) and Gonca Subaş1 (2010) have used (FLCAS) to measure the students`anxiety at different educational levels and in different countries similar to Lebanon geographically and educationally, which makes it a valid and reliable instrument to be used in Lebanon.

FLCAS questionnaire is a five-point likert scale ranged between Strongly Agree, Agree, Neither agree nor disagree, Disagree, and Strongly Disagree ( SA,A,NAND,DA,SD). It consisted of 33 items, 8 items were for measuring the communication anxiety $(1,9,14,18,24,27,29,32), 9$ items for measuring the fear of negative evaluation $(3,7,13,15,20,23,25,31,33), 5$ items for measuring test anxiety $(2,8,10,19,21)$ and the remaining 11 items, were for measuring students` anxiety of English classes in general.

This experimental quantitative study depended on the use of the FLCAS to examine the effects of anxiety on students' EFL speaking skill in Tripoli secondary schools; and on the causal relationship between adapting the Communicative Language Learning approach (CLL) and students' performance and responses to it. Thus, the implementation of CLL approach through various activities was prepared and guided by the researcher and teachers such as: transcripts, texts, dialogues, conversations, cards games, and furthermore examination of a grammar point, working on pronunciation, creating new sentences with words from the transcripts, and ending the course with reflection on the experience, supported the researcher investigating the effect of CLL on students speaking anxiety.

In order to achieve the differences between control group and experimental group concerning students' level of anxiety and students' oral performance in speaking English along with the differences between Public students' achievement in speaking English Language and those in the Private sectors, the traditional method of teaching English as a foreign language was implemented in the two selected schools' control group classes, while the CLL approach was followed with the experimental groups in the two selected schools.

\subsection{Procedure}

After acquiring the approval of the ministry of higher education and the consent letters from the principals of the selected high schools to carry out the study at their schools. A meeting was held with the concerned EFL teachers and an agreement was orally signed to cooperate and help students overcome their speaking English anxiety. Then, the researcher with the class teachers, informed the students about the study and each one received a consent letter to be signed by his/her parent. For an effective implementation of the CLL approach Peyton, 1993; Montgomery, 2001; and Cooper\& 
Kiger, 2003, suggested steps were followed. Thus, the researcher had to meet the teachers in charge of conducting CLL approach many times before starting the intervention to discuss the procedure of conduction and how to guide, direct, facilitate, motivate, follow up and assess students speaking tasks. In addition to weekly meetings to monitors the implementation of CLL and students' progress. The students of the experimental group students in both private and public sectors were promised that their names and grades will be confidential.

Later on, the 117 students, in both secondary school sectors, were asked to complete the prequestionnaire of the foreign language classroom anxiety scale according to their own point of views, so that we can measure their foreign language anxiety before implementing the CLL approach.

The CLL implementation was going in parallel in both experimental classes in both public and private high schools for a period of six months with an average of two periods per week, which was considered not enough for such an approach. Moreover, the researcher follow up was continuous through attending classes, observing the agreed on activities in conducting the CLL approach, the students` behavior during oral communication, and students`speaking skill development.

The researcher coordinated every step with the teachers who acted as controllers, participants, tutors, organizers, directors, monitors, and correctors who aimed to facilitate the students' speaking language learning process. Above all, the teachers with the researcher were able to analyze the students' needs, face their fears and problems, and could find fruitful solutions that helped them to a certain extent overcome their speaking anxiety.

Henceforth, the teachers encouraged the students to speak using their foreign and native language in discussing their favorable topics selected from their grade ten books or the topics assigned by the researcher and teachers. During the process, teachers used to translate what students have said in their native language into English written transcripts on the board then worked on them in a way that students` understanding was guaranteed and anxiety level was decreased. For further exploration of students` generated language, various activities were conducted; individual work where each student had the opportunity to translate others' utterances, after writing the transcripts on the blackboard, group activities from examining a grammar point, to working on pronunciation of a particular phrase, or creating new sentences with vocabulary, and from role plays to dialogues, conversations and presentations, that usually ended up with reflection sessions every time it was needed.

After six months of implementing the CLL approach, both the experimental and the control groups were given the same FLCAS as a posttest.

At the end, the questionnaires results were analyzed and summarized, using SPSS (Statistic Package for the Social Science), a Windows based program to carry out data entry and to create tables and graphs and for data analysis that helped comparing between pre-test and post-test means, percentages, coefficients of students` scores. Furthermore, the correlations of the pre and post collected data were compared between the control group and the experimental one and between the private and public sectors to measure students' English oral performance once the CLL approach was completed. Finally, using SPSS, afforded enough statistical analysis to evaluate the students` speaking language improvement.

\section{RESUltS AND DisCUSSION}

In this survey study, the variables which were connected to the sub-categories such as language anxiety, oral testing (grades), interview, behaviors observation were searched. The Statistic Package for Social Sciences (SPSS) was used to analyze the data quantitatively. The data obtained from the questionnaire were analyzed through descriptive statistics, Independent-Samples T-Test, and correlation.

By means of these categories, the differences of foreign language speaking anxiety levels between control and experimental groups, between public and private sectors before and after implementing the CLL approach were described the following tables.

\subsection{Descriptive Statistics Of FLCAS Results}

First, reliability coefficients were computed. Looking at the research questions regarding the students level of anxiety to each item of FLCAS and how did implementing the CLL method affect the level of students` anxiety in both private and public sectors. 
With possible scores on the FLCAS items ranging from zero to five, the following criteria, used by many researches such as Piechurska-Kuciel (2008) and Alessia Occhipinti (2009), to measure language anxiety were established and used in this study:

- 0-2.5 Low Anxiety

- 2.5-3.5 Moderate Anxiety

- 3.5-5 High Anxiet

To answer the study questions the following statistical operations were done

\section{FLCAS Prelpost results}

Table3. Q1. Anxiety pre test

\begin{tabular}{|c|c|c|c|c|c|c|c|}
\hline \multirow[t]{3}{*}{ School } & \multirow[t]{3}{*}{ Q1 } & & \multicolumn{3}{|c|}{ Group } & \multicolumn{2}{|c|}{ Total } \\
\hline & & \multicolumn{2}{|c|}{ Experimental } & \multicolumn{2}{|c|}{ Control } & & \\
\hline & & $\mathrm{N}$ & $\%$ & $\mathrm{~N}$ & $\%$ & $\mathrm{~N}$ & $\%$ \\
\hline \multirow{6}{*}{ Public } & SA & 3 & $11.5 \%$ & 0 & & 3 & $5.2 \%$ \\
\hline & $\mathrm{A}$ & 11 & $42.3 \%$ & 8 & $25.0 \%$ & 19 & $32.8 \%$ \\
\hline & NAND & 10 & $38.5 \%$ & 14 & $43.8 \%$ & 24 & $41.4 \%$ \\
\hline & DA & 1 & $3.8 \%$ & 6 & $18.8 \%$ & 7 & $12.1 \%$ \\
\hline & SD & 1 & $3.8 \%$ & 4 & $12.5 \%$ & 5 & $8.6 \%$ \\
\hline & Total & 26 & $100.0 \%$ & 32 & $100.0 \%$ & 58 & $100.0 \%$ \\
\hline \multirow[t]{6}{*}{ Private } & SA & 0 & $0 \%$ & 6 & $18.8 \%$ & 6 & $10.2 \%$ \\
\hline & $\mathrm{A}$ & 6 & $22.2 \%$ & 3 & $9.4 \%$ & 9 & $15.3 \%$ \\
\hline & NAND & 3 & $11.1 \%$ & 4 & $12.5 \%$ & 7 & $11.9 \%$ \\
\hline & DA & 5 & $18.5 \%$ & 4 & $12.5 \%$ & 9 & $15.3 \%$ \\
\hline & SD & 13 & $48.1 \%$ & 15 & $46.9 \%$ & 28 & $47.5 \%$ \\
\hline & Total & 27 & $100.0 \%$ & 32 & $100.0 \%$ & 59 & $100.0 \%$ \\
\hline \multirow[t]{6}{*}{ Total } & SA & 3 & $5.7 \%$ & 6 & $9.4 \%$ & 9 & $7.7 \%$ \\
\hline & $\mathrm{A}$ & 17 & $32.1 \%$ & 11 & $17.2 \%$ & 28 & $23.9 \%$ \\
\hline & NAND & 13 & $24.5 \%$ & 18 & $28.1 \%$ & 31 & $26.5 \%$ \\
\hline & $\mathrm{DA}$ & 6 & $11.3 \%$ & 10 & $15.6 \%$ & 16 & $13.7 \%$ \\
\hline & SD & 14 & $26.4 \%$ & 19 & $29.7 \%$ & 33 & $28.2 \%$ \\
\hline & Total & 53 & $100.0 \%$ & 64 & $100.0 \%$ & 1 & $100.0 \%$ \\
\hline
\end{tabular}

Table 3 revealed that $38 \%$ of the public school participants strongly agree and agree that they never felt quite sure of themselves when they used EFL in the speaking class while $41.4 \%$ neither agree nor disagree, and $20.7 \%$ disagree and strongly disagree respectively. Whereas $25.5 \%$ of the private school participants agree and strongly disagree, $11.9 \%$ neither agree nor disagree, and $62.8 \%$ disagree and strongly disagree with the same statement. Such numbers indicate that public school participants have more speaking language anxiety than private school participants, less confidence and lack motivation.

Table4. Q1. Anxiety post test results

\begin{tabular}{|c|c|c|c|c|c|c|c|}
\hline \multirow[t]{3}{*}{ School } & \multirow[t]{3}{*}{ Q1 } & \multicolumn{4}{|c|}{ Group } & \multicolumn{2}{|c|}{ Total } \\
\hline & & \multicolumn{2}{|c|}{ Experimental } & \multicolumn{2}{|c|}{ Control } & & \\
\hline & & $\mathrm{N}$ & $\%$ & $\mathrm{~N}$ & $\%$ & $\mathrm{~N}$ & $\%$ \\
\hline \multirow[t]{6}{*}{ Public } & SA & 2 & $7.7 \%$ & 16 & $69.6 \%$ & 18 & $36.7 \%$ \\
\hline & A & 0 & & 7 & $30.4 \%$ & 7 & $14.3 \%$ \\
\hline & NAND & & & & & & \\
\hline & DA & 5 & $19.2 \%$ & 0 & & 5 & $10.2 \%$ \\
\hline & SD & 19 & $73.1 \%$ & 0 & & 19 & $38.8 \%$ \\
\hline & Total & 26 & $100.0 \%$ & 23 & $100.0 \%$ & 49 & $100.0 \%$ \\
\hline \multirow[t]{6}{*}{ Private } & SA & 0 & & 4 & $16.7 \%$ & 4 & $7.8 \%$ \\
\hline & A & 0 & & 9 & $37.5 \%$ & 9 & $17.6 \%$ \\
\hline & NAND & 0 & & 5 & $20.8 \%$ & 5 & $9.8 \%$ \\
\hline & DA & 14 & $51.9 \%$ & 6 & $25.0 \%$ & 20 & $39.2 \%$ \\
\hline & SD & 13 & $48.1 \%$ & 0 & & 13 & $25.5 \%$ \\
\hline & Total & 27 & $100.0 \%$ & 24 & $100.0 \%$ & 51 & $100.0 \%$ \\
\hline \multirow[t]{6}{*}{ Total } & SA & 2 & $3.8 \%$ & 20 & $42.6 \%$ & 22 & $22.0 \%$ \\
\hline & A & 0 & & 16 & $34.0 \%$ & 16 & $16.0 \%$ \\
\hline & NAND & 0 & & 5 & $10.6 \%$ & 5 & $5.0 \%$ \\
\hline & DA & 19 & $35.8 \%$ & 6 & $12.8 \%$ & 25 & $25.0 \%$ \\
\hline & SD & 32 & $60.4 \%$ & 0 & & 32 & $32.0 \%$ \\
\hline & Total & 53 & $100.0 \%$ & 47 & $100.0 \%$ & 100 & $100.0 \%$ \\
\hline
\end{tabular}


Table 4 of the anxiety posttest showed that $7.7 \%$ of the public participants in the experimental group strongly agree and agree with the studied statement, while $0 \%$ neither agree nor disagree, $92.3 \%$ of the participants disagree and strongly disagree respectively, while in the control group, $100 \%$ of the participants agree and strongly agree, $0 \%$ neither agree nor disagree and $0 \%$ disagree with the same statement. Whereas $100 \%$ of the participants in the private experimental group disagree and strongly disagree with the same statement, while in the control group, $54.2 \%$ of the participants agree with the tested statement, $20.8 \%$ neither agree nor disagree, and 25\% disagree with it. Such differences in results between the control and experimental groups indicate that anxiety has dramatically decreased and the participants in the experimental group were more motivated and more confident after the implementation of the CLL approach, especially in the public school.

Table5. Q2. Anxiety pre test

\begin{tabular}{|c|c|c|c|c|c|c|c|}
\hline \multirow[t]{3}{*}{ School } & \multirow[t]{3}{*}{$\mathbf{Q 2}$} & \multicolumn{4}{|c|}{ Group } & \multicolumn{2}{|c|}{ Total } \\
\hline & & \multicolumn{2}{|c|}{ Experimental } & \multicolumn{2}{|c|}{ Control } & & \\
\hline & & $\mathrm{N}$ & $\%$ & $\mathrm{~N}$ & $\%$ & $\mathrm{~N}$ & $\%$ \\
\hline \multirow[t]{6}{*}{ Public } & SA & 2 & $7.7 \%$ & 4 & $12.5 \%$ & 6 & $10.3 \%$ \\
\hline & A & 11 & $42.3 \%$ & 6 & $18.8 \%$ & 17 & $29.3 \%$ \\
\hline & NAND & 0 & & 8 & $25.0 \%$ & 8 & $13.8 \%$ \\
\hline & DA & 10 & $38.5 \%$ & 11 & $34.4 \%$ & 21 & $36.2 \%$ \\
\hline & SD & 3 & $11.5 \%$ & 3 & $9.4 \%$ & 6 & $10.3 \%$ \\
\hline & Total & 26 & $100.0 \%$ & 32 & $100.0 \%$ & 58 & $100.0 \%$ \\
\hline \multirow[t]{6}{*}{ Private } & $\mathrm{SA}$ & 6 & $23.1 \%$ & 14 & $43.8 \%$ & 20 & $34.5 \%$ \\
\hline & $\mathrm{A}$ & 4 & $15.4 \%$ & 1 & $3.1 \%$ & 5 & $8.6 \%$ \\
\hline & NAND & 5 & $19.2 \%$ & 3 & $9.4 \%$ & 8 & $13.8 \%$ \\
\hline & DA & 4 & $15.4 \%$ & 5 & $15.6 \%$ & 9 & $15.5 \%$ \\
\hline & SD & 7 & $26.9 \%$ & 9 & $28.1 \%$ & 16 & $27.6 \%$ \\
\hline & Total & 26 & $100.0 \%$ & 32 & $100.0 \%$ & 58 & $100.0 \%$ \\
\hline \multirow[t]{6}{*}{ Total } & SA & 8 & $15.4 \%$ & 18 & $28.1 \%$ & 26 & $22.4 \%$ \\
\hline & $\mathrm{A}$ & 15 & $28.8 \%$ & 7 & $10.9 \%$ & 22 & $19.0 \%$ \\
\hline & NAND & 5 & $9.6 \%$ & 11 & $17.2 \%$ & 16 & $13.8 \%$ \\
\hline & DA & 14 & $26.9 \%$ & 16 & $25.0 \%$ & 30 & $25.9 \%$ \\
\hline & SD & 10 & $19.2 \%$ & 12 & $18.8 \%$ & 22 & $19.0 \%$ \\
\hline & Total & 52 & $100.0 \%$ & 64 & $100.0 \%$ & 116 & $100.0 \%$ \\
\hline
\end{tabular}

Table 5 showed that $39.6 \%$ of the public school participants strongly agree and agree that they did not worry about making mistakes in foreign language classes, $13.8 \%$ neither agree nor disagree and $46.5 \%$ disagree and strongly disagree respectively. Whereas $43.1 \%$ of the private school participants agree and strongly disagree with the same statement, $13.8 \%$ neither agree nor disagree, and $43.1 \%$ disagree and strongly disagree. Such results indicated that a good number of participants were careless about learning a foreign language and lack motivation.

Table6. Q2. Anxiety post test results

\begin{tabular}{|c|c|c|c|c|c|c|c|}
\hline \multirow[t]{3}{*}{ School } & \multirow[t]{3}{*}{ Q2 } & \multicolumn{4}{|c|}{ Group } & \multicolumn{2}{|c|}{ Total } \\
\hline & & \multicolumn{2}{|c|}{ Experimental } & \multicolumn{2}{|c|}{ Control } & & \\
\hline & & $\mathrm{N}$ & $\%$ & $\mathrm{~N}$ & $\%$ & $\mathrm{~N}$ & $\%$ \\
\hline \multirow{6}{*}{ Public } & SA & 10 & $38.5 \%$ & 0 & & 10 & $20.4 \%$ \\
\hline & $\mathrm{A}$ & 6 & $23.1 \%$ & 2 & $8.7 \%$ & 8 & $16.3 \%$ \\
\hline & NAND & 0 & & 2 & $8.7 \%$ & 2 & $4.1 \%$ \\
\hline & DA & 8 & $30.8 \%$ & 4 & $17.4 \%$ & 12 & $24.5 \%$ \\
\hline & $\mathrm{SD}$ & 2 & $7.7 \%$ & 15 & $65.2 \%$ & 17 & $34.7 \%$ \\
\hline & Total & 26 & $100.0 \%$ & 23 & $100.0 \%$ & 49 & $100.0 \%$ \\
\hline \multirow{6}{*}{ Private } & SA & 2 & $7.4 \%$ & 5 & $20.8 \%$ & 7 & $13.7 \%$ \\
\hline & $\mathrm{A}$ & 7 & $25.9 \%$ & 3 & $12.5 \%$ & 10 & $19.6 \%$ \\
\hline & NAND & 7 & $25.9 \%$ & 4 & $16.7 \%$ & 11 & $21.6 \%$ \\
\hline & $\mathrm{DA}$ & 8 & $29.6 \%$ & 7 & $29.2 \%$ & 15 & $29.4 \%$ \\
\hline & SD & 3 & $11.1 \%$ & 5 & $20.8 \%$ & 8 & $15.7 \%$ \\
\hline & Total & 27 & $100.0 \%$ & 24 & $100.0 \%$ & 51 & $100.0 \%$ \\
\hline \multirow{6}{*}{ Total } & SA & 12 & $22.6 \%$ & 5 & $10.6 \%$ & 17 & $17.0 \%$ \\
\hline & $\mathrm{A}$ & 13 & $24.5 \%$ & 5 & $10.6 \%$ & 18 & $18.0 \%$ \\
\hline & NAND & 7 & $13.2 \%$ & 6 & $12.8 \%$ & 13 & $13.0 \%$ \\
\hline & DA & 16 & $30.2 \%$ & 11 & $23.4 \%$ & 27 & $27.0 \%$ \\
\hline & SD & 5 & $9.4 \%$ & 20 & $42.6 \%$ & 25 & $25.0 \%$ \\
\hline & Total & 53 & $100.0 \%$ & 47 & $100.0 \%$ & 100 & $100.0 \%$ \\
\hline
\end{tabular}


Table 6 of the anxiety posttest revealed that $61.6 \%$ of the participants in the public experimental group strongly agree and agree respectively that they don't worry about making mistakes in foreign language classes and none of the participants neither agree nor disagree with the statement, as well as $38.5 \%$ of the participants disagree and strongly disagree respectively. While in the control group, $8.7 \%$ of the participants agree and strongly agree with the same statement, $8.7 \%$ of the participants neither agree nor disagree, and $82.6 \%$ disagree with it. Whereas $33.3 \%$ of the private participants in the experimental group agree and strongly agree with the same statement, $25.9 \%$ neither agree nor disagree with the statement and $40.7 \%$ of the participants disagree with it. While in the control group, $33.3 \%$ of the participants agree with the statement, $16.7 \%$ neither agree nor disagree, and $50 \%$ disagree with it. Such differences in the results between the control and experimental groups indicate that anxiety has dramatically decreased in the experimental groups and participants in the public school are more confident and responsible after the implementation of the CLL approach.

Table7. Q3. Anxiety pre test

\begin{tabular}{|c|c|c|c|c|c|c|c|}
\hline \multirow[t]{3}{*}{ School } & \multirow[t]{3}{*}{ Q3 } & \multicolumn{4}{|c|}{ Group } & \multicolumn{2}{|c|}{ Total } \\
\hline & & \multicolumn{2}{|c|}{ Experimental } & \multicolumn{2}{|c|}{ Control } & & \\
\hline & & $\mathrm{N}$ & $\%$ & $\mathrm{~N}$ & $\%$ & $\mathrm{~N}$ & $\%$ \\
\hline \multirow[t]{6}{*}{ Public } & SA & 2 & $7.7 \%$ & 2 & $6.3 \%$ & 4 & $6.9 \%$ \\
\hline & A & 10 & $38.5 \%$ & 9 & $28.1 \%$ & 19 & $32.8 \%$ \\
\hline & NAND & 4 & $15.4 \%$ & 8 & $25.0 \%$ & 12 & $20.7 \%$ \\
\hline & $\mathrm{DA}$ & 9 & $34.6 \%$ & 6 & $18.8 \%$ & 15 & $25.9 \%$ \\
\hline & SD & 1 & $3.8 \%$ & 7 & $21.9 \%$ & 8 & $13.8 \%$ \\
\hline & Total & 26 & $100.0 \%$ & 32 & $100.0 \%$ & 58 & $100.0 \%$ \\
\hline \multirow[t]{6}{*}{ Private } & $\mathrm{SA}$ & 1 & $3.7 \%$ & 2 & $6.7 \%$ & 3 & $5.3 \%$ \\
\hline & A & 2 & $7.4 \%$ & 0 & & 2 & $3.5 \%$ \\
\hline & NAND & 4 & $14.8 \%$ & 1 & $3.3 \%$ & 5 & $8.8 \%$ \\
\hline & DA & 8 & $29.6 \%$ & 8 & $26.7 \%$ & 16 & $28.1 \%$ \\
\hline & SD & 12 & $44.4 \%$ & 19 & $63.3 \%$ & 31 & $54.4 \%$ \\
\hline & Total & 27 & $100.0 \%$ & 30 & $100.0 \%$ & 57 & $100.0 \%$ \\
\hline \multirow[t]{6}{*}{ Total } & $\mathrm{SA}$ & 3 & $5.7 \%$ & 4 & $6.5 \%$ & 7 & $6.1 \%$ \\
\hline & $\mathrm{A}$ & 12 & $22.6 \%$ & 9 & $14.5 \%$ & 21 & $18.3 \%$ \\
\hline & NAND & 8 & $15.1 \%$ & 9 & $14.5 \%$ & 17 & $14.8 \%$ \\
\hline & DA & 17 & $32.1 \%$ & 14 & $22.6 \%$ & 31 & $27.0 \%$ \\
\hline & SD & 13 & $24.5 \%$ & 26 & $41.9 \%$ & 39 & $33.9 \%$ \\
\hline & Total & 53 & $100.0 \%$ & 62 & $100.0 \%$ & 115 & $100.0 \%$ \\
\hline
\end{tabular}

Table 7 showed that $39.7 \%$ of the public school participants strongly agree and agree that they tremble when they know that they are going to be called on in foreign language classes, $20.7 \%$ neither agree nor disagree, and $39.7 \%$ disagree and strongly disagree respectively. Whereas $8.8 \%$ of the private school participants agree and strongly disagree with the same statement $8.8 \%$ neither agree nor disagree, and $82.5 \%$ disagree and strongly disagree. Such results indicated that a good number of participants in the public school had fear and irresponsibility towards learning a foreign language, less confidence and more anxiety than private school students.

Table8. Q3. Anxiety post test results

\begin{tabular}{|c|c|c|c|c|c|c|c|}
\hline \multirow[t]{3}{*}{ School } & \multirow[t]{3}{*}{ Q3 } & \multicolumn{4}{|c|}{ Group } & \multicolumn{2}{|c|}{ Total } \\
\hline & & \multicolumn{2}{|c|}{ Experimental } & \multicolumn{2}{|c|}{ Control } & & \\
\hline & & $\mathrm{N}$ & $\%$ & $\mathrm{~N}$ & $\%$ & $\mathrm{~N}$ & $\%$ \\
\hline \multirow[t]{6}{*}{ Public } & SA & 0 & & 8 & $36.4 \%$ & 8 & $16.7 \%$ \\
\hline & A & 0 & & 13 & $59.1 \%$ & 13 & $27.1 \%$ \\
\hline & NAND & & & & & & \\
\hline & DA & 5 & $19.2 \%$ & 1 & $4.5 \%$ & 6 & $12.5 \%$ \\
\hline & SD & 21 & $80.8 \%$ & 0 & & 21 & $43.8 \%$ \\
\hline & Total & 26 & $100.0 \%$ & 22 & $100.0 \%$ & 48 & $100.0 \%$ \\
\hline \multirow[t]{6}{*}{ Private } & SA & 1 & $3.7 \%$ & 0 & & 1 & $2.0 \%$ \\
\hline & A & 0 & & 1 & $4.2 \%$ & 1 & $2.0 \%$ \\
\hline & NAND & 0 & & 2 & $8.3 \%$ & 2 & $3.9 \%$ \\
\hline & DA & 4 & $14.8 \%$ & 12 & $50.0 \%$ & 16 & $31.4 \%$ \\
\hline & SD & 22 & $81.5 \%$ & 9 & $37.5 \%$ & 31 & $60.8 \%$ \\
\hline & Total & 27 & $100.0 \%$ & 24 & $100.0 \%$ & 51 & $100.0 \%$ \\
\hline \multirow[t]{3}{*}{ Total } & SA & 1 & $1.9 \%$ & 8 & $17.4 \%$ & 9 & $9.1 \%$ \\
\hline & $\mathrm{A}$ & 0 & & 14 & $30.4 \%$ & 14 & $14.1 \%$ \\
\hline & NAND & 0 & & 2 & $4.3 \%$ & 2 & $2.0 \%$ \\
\hline
\end{tabular}




\begin{tabular}{|l|l|l|l|l|l|l|l|}
\hline \multirow{2}{*}{} & DA & 9 & $17.0 \%$ & 13 & $28.3 \%$ & 22 & $22.2 \%$ \\
\cline { 2 - 8 } & SD & 43 & $81.1 \%$ & 9 & $19.6 \%$ & 52 & $52.5 \%$ \\
\cline { 2 - 8 } & Total & 53 & $100.0 \%$ & 46 & $100.0 \%$ & 99 & $100.0 \%$ \\
\hline
\end{tabular}

Table 8 of the anxiety posttest revealed that $0 \%$ of the participants in the public experimental group strongly agree and agree respectively with that they tremble when they know that they are going to be called on in foreign language class, $0 \%$ of the participants neither agree nor disagree with the statement, and $100 \%$ of the participants disagree and strongly disagree respectively. While in the control group, $59.5 \%$ of the participants agree and strongly agree with with the same statement, $0 \%$ of the participants neither agree nor disagree, and $4.5 \%$ disagree with the statement. Whereas $0 \%$ of the participants in the experimental group of the private school agree and strongly agree with the same statement, $0 \%$ neither agree nor disagree with the statement, and $100 \%$ of the participants disagree with it. While in the control group, $4.2 \%$ of the participants agree with the statement, $8.3 \%$ neither agree nor disagree, and $87.7 \%$ disagree with it. Such differences in the results between the control and experimental groups indicate that anxiety has dramatically decreased in the experimental groups and the participants have high sense of confidence and responsibility as a result of implementing the CLL approach.

Table9. Q4. Anxiety pre test

\begin{tabular}{|c|c|c|c|c|c|c|c|}
\hline \multirow[t]{3}{*}{ School } & \multirow[t]{3}{*}{ Q4 } & \multicolumn{4}{|c|}{ Group } & \multicolumn{2}{|c|}{ Total } \\
\hline & & \multicolumn{2}{|c|}{ Experimental } & \multicolumn{2}{|c|}{ Control } & & \\
\hline & & $\mathrm{N}$ & $\%$ & $\mathrm{~N}$ & $\%$ & $\mathrm{~N}$ & $\%$ \\
\hline \multirow{6}{*}{ Public } & SA & 3 & $11.5 \%$ & 5 & $15.6 \%$ & 8 & $13.8 \%$ \\
\hline & $\mathrm{A}$ & 8 & $30.8 \%$ & 8 & $25.0 \%$ & 16 & $27.6 \%$ \\
\hline & NAND & 2 & $7.7 \%$ & 9 & $28.1 \%$ & 11 & $19.0 \%$ \\
\hline & DA & 11 & $42.3 \%$ & 4 & $12.5 \%$ & 15 & $25.9 \%$ \\
\hline & SD & 2 & $7.7 \%$ & 6 & $18.8 \%$ & 8 & $13.8 \%$ \\
\hline & Total & 26 & $100.0 \%$ & 32 & $100.0 \%$ & 58 & $100.0 \%$ \\
\hline \multirow[t]{6}{*}{ Private } & $\mathrm{SA}$ & 0 & & 3 & $9.4 \%$ & 3 & $5.1 \%$ \\
\hline & $\mathrm{A}$ & 2 & $7.4 \%$ & 0 & & 2 & $3.4 \%$ \\
\hline & NAND & 4 & $14.8 \%$ & 1 & $3.1 \%$ & 5 & $8.5 \%$ \\
\hline & DA & 7 & $25.9 \%$ & 18 & $56.3 \%$ & 25 & $42.4 \%$ \\
\hline & SD & 14 & $51.9 \%$ & 10 & $31.3 \%$ & 24 & $40.7 \%$ \\
\hline & Total & 27 & $100.0 \%$ & 32 & $100.0 \%$ & 59 & $100.0 \%$ \\
\hline \multirow{6}{*}{ Total } & $\mathrm{SA}$ & 3 & $5.7 \%$ & 8 & $12.5 \%$ & 11 & $9.4 \%$ \\
\hline & $\mathrm{A}$ & 10 & $18.9 \%$ & 8 & $12.5 \%$ & 18 & $15.4 \%$ \\
\hline & NAND & 6 & $11.3 \%$ & 10 & $15.6 \%$ & 16 & $13.7 \%$ \\
\hline & DA & 18 & $34.0 \%$ & 22 & $34.4 \%$ & 40 & $34.2 \%$ \\
\hline & SD & 16 & $30.2 \%$ & 16 & $25.0 \%$ & 32 & $27.4 \%$ \\
\hline & Total & 53 & $100.0 \%$ & 64 & $100.0 \%$ & 117 & $100.0 \%$ \\
\hline
\end{tabular}

Table 9 revealed that $41.4 \%$ of the public school participants strongly agree and agree that it frightens them when they don't understand what the teacher says in the foreign language, $19 \%$ neither agree nor disagree, and $39.7 \%$ disagree and strongly disagree respectively with the statement. Whereas $8.5 \%$ of the private school participants agree and strongly disagree with the same statement, $8.5 \%$ neither agree nor disagree, and $83.1 \%$ disagree and strongly disagree with the statement. Such results indicate that a good number of participants in the public school are irresponsible, have less confidence, fear learning a foreign language, and more anxious than the private school students.

Table10. Q4. Anxiety post test results

\begin{tabular}{|c|c|c|c|c|c|c|c|}
\hline \multirow[t]{3}{*}{ School } & \multirow[t]{3}{*}{ Q4 } & \multicolumn{4}{|c|}{ Group } & \multicolumn{2}{|c|}{ Total } \\
\hline & & \multicolumn{2}{|c|}{ Experimental } & \multicolumn{2}{|c|}{ Control } & & \\
\hline & & $\mathrm{N}$ & $\%$ & $\mathrm{~N}$ & $\%$ & $\mathrm{~N}$ & $\%$ \\
\hline \multirow{6}{*}{ Public } & SA & 0 & & 8 & $34.8 \%$ & 8 & $16.3 \%$ \\
\hline & $\mathrm{A}$ & 0 & & 13 & $56.5 \%$ & 13 & $26.5 \%$ \\
\hline & NAND & 0 & & 2 & $8.7 \%$ & 2 & $4.1 \%$ \\
\hline & DA & 18 & $69.2 \%$ & 0 & & 18 & $36.7 \%$ \\
\hline & SD & 8 & $30.8 \%$ & 0 & & 8 & $16.3 \%$ \\
\hline & Total & 26 & $100.0 \%$ & 23 & $100.0 \%$ & 49 & $100.0 \%$ \\
\hline \multirow[t]{4}{*}{ Private } & $\mathrm{SA}$ & 0 & & 1 & $4.2 \%$ & 1 & $2.0 \%$ \\
\hline & $\mathrm{A}$ & 0 & & 1 & $4.2 \%$ & 1 & $2.0 \%$ \\
\hline & NAND & 2 & $7.4 \%$ & 3 & $12.5 \%$ & 5 & $9.8 \%$ \\
\hline & DA & 13 & $48.1 \%$ & 9 & $37.5 \%$ & 22 & $43.1 \%$ \\
\hline
\end{tabular}


Could Cll Approach be a Remedy for Tripoli Secondary Students Speaking Skills?

\begin{tabular}{|l|l|l|l|l|l|l|l|}
\hline & SD & 12 & $44.4 \%$ & 10 & $41.7 \%$ & 22 & $43.1 \%$ \\
\cline { 2 - 8 } & Total & 27 & $100.0 \%$ & 24 & $100.0 \%$ & 51 & $100.0 \%$ \\
\hline \multirow{5}{*}{ Total } & SA & 0 & & 9 & $19.1 \%$ & 9 & $9.0 \%$ \\
\cline { 2 - 8 } & A & 0 & & 14 & $29.8 \%$ & 14 & $14.0 \%$ \\
\cline { 2 - 8 } & NAND & 2 & $3.8 \%$ & 5 & $10.6 \%$ & 7 & $7.0 \%$ \\
\cline { 2 - 8 } & DA & 31 & $58.5 \%$ & 9 & $19.1 \%$ & 40 & $40.0 \%$ \\
\cline { 2 - 8 } & SD & 20 & $37.7 \%$ & 10 & $21.3 \%$ & 30 & $30.0 \%$ \\
\cline { 2 - 8 } & Total & 53 & $100.0 \%$ & 47 & $100.0 \%$ & 100 & $100.0 \%$ \\
\hline
\end{tabular}

Table 10 of the anxiety posttest revealed that $0 \%$ of the participants in the public experimental group strongly agree and agree respectively with that it frightens them when they don't understand what the teacher says in the foreign language, $0 \%$ of the participants neither agree nor disagree with the statement, and $100 \%$ of the participants disagree and strongly disagree respectively. While in the control group, $91.3 \%$ of the participants agree and strongly agree with the same statement, $8.7 \%$ of the participants neither agree nor disagree, and $0 \%$ disagree with the statement. Whereas $0 \%$ of the participants in the private experimental group agree and strongly agree with the same statement, $7.4 \%$ neither agree nor disagree with the statement, and $92.5 \%$ of the participants disagree with it. While in the control group, $8.4 \%$ of the participants agree with the statement, $12.5 \%$ neither agree nor disagree, and $79.2 \%$ disagree with it. Such differences in the results between the control and experimental groups indicate that anxiety has dramatically decreased in the experimental groups and the participants had no fear of the foreign language, high self confidence and responsibility after the implementation of the CLL approach. Moreover, these results indicated that public school participants were more influenced by the CLL approach.

Table11. Q5. Anxiety pre test

\begin{tabular}{|c|c|c|c|c|c|c|c|}
\hline \multirow[t]{3}{*}{ School } & \multirow[t]{3}{*}{ Q5 } & \multicolumn{4}{|c|}{ Group } & \multicolumn{2}{|c|}{ Total } \\
\hline & & \multicolumn{2}{|c|}{ Experimental } & \multicolumn{2}{|c|}{ Control } & & \\
\hline & & $\mathrm{N}$ & $\%$ & $\mathrm{~N}$ & $\%$ & $\mathrm{~N}$ & $\%$ \\
\hline \multirow[t]{6}{*}{ Public } & SA & 10 & $38.5 \%$ & 4 & $12.5 \%$ & 14 & $24.1 \%$ \\
\hline & A & 11 & $42.3 \%$ & 13 & $40.6 \%$ & 24 & $41.4 \%$ \\
\hline & NAND & 3 & $11.5 \%$ & 11 & $34.4 \%$ & 14 & $24.1 \%$ \\
\hline & DA & 2 & $7.7 \%$ & 4 & $12.5 \%$ & 6 & $10.3 \%$ \\
\hline & SD & 0 & $0.0 \%$ & 0 & $0.0 \%$ & 0 & $0.0 \%$ \\
\hline & Total & 26 & $100.0 \%$ & 32 & $100.0 \%$ & 58 & $100.0 \%$ \\
\hline \multirow[t]{6}{*}{ Private } & SA & 5 & $18.5 \%$ & 18 & $56.3 \%$ & 23 & $39.0 \%$ \\
\hline & A & 4 & $14.8 \%$ & 0 & & 4 & $6.8 \%$ \\
\hline & NAND & 4 & $14.8 \%$ & 6 & $18.8 \%$ & 10 & $16.9 \%$ \\
\hline & DA & 6 & $22.2 \%$ & 2 & $6.3 \%$ & 8 & $13.6 \%$ \\
\hline & SD & 8 & $29.6 \%$ & 6 & $18.8 \%$ & 14 & $23.7 \%$ \\
\hline & Total & 27 & $100.0 \%$ & 32 & $100.0 \%$ & 59 & $100.0 \%$ \\
\hline \multirow[t]{6}{*}{ Total } & SA & 15 & $28.3 \%$ & 22 & $34.4 \%$ & 37 & $31.6 \%$ \\
\hline & A & 15 & $28.3 \%$ & 13 & $20.3 \%$ & 28 & $23.9 \%$ \\
\hline & NAND & 7 & $13.2 \%$ & 17 & $26.6 \%$ & 24 & $20.5 \%$ \\
\hline & DA & 8 & $15.1 \%$ & 6 & $9.4 \%$ & 14 & $12.0 \%$ \\
\hline & SD & 8 & $15.1 \%$ & 6 & $9.4 \%$ & 14 & $12.0 \%$ \\
\hline & Total & 53 & $100.0 \%$ & 64 & $100.0 \%$ & 117 & $100.0 \%$ \\
\hline
\end{tabular}

Table 11 showed that $65.5 \%$ of the public school participants strongly agree and agree that it wouldn't bother them at all to take more foreign language classes, $24.1 \%$ neither agree nor disagree, and $10.3 \%$ disagree and strongly disagree respectively with the statement. Whereas $45.8 \%$ of the private school participants agree and strongly disagree with the same statement,16.9\% neither agree nor disagree, and $37.3 \%$ disagree and strongly disagree with the statement. Such results indicate that although the majority of the participants in the public and private schools do not mind having more EFL courses, $34.4 \%$ of the public participants and $44.2 \%$ of the private participants showed no motivation and irresponsibility towards learning more EFL courses.

Table12. Q5. Anxiety post test results

\begin{tabular}{|l|l|l|l|l|l|l|l|}
\hline \multirow{3}{*}{ School } & Q5 & \multicolumn{2}{l|}{ Group } & \multicolumn{2}{l|}{ Total } \\
\cline { 2 - 9 } & \multicolumn{2}{|l|}{ Experimental } & \multicolumn{2}{l|}{ Control } & & \\
\cline { 2 - 9 } & & $\mathrm{N}$ & $\%$ & $\mathrm{~N}$ & $\%$ & $\mathrm{~N}$ & $\%$ \\
\hline \multirow{3}{*}{ Public } & SA & 4 & $16.0 \%$ & 0 & & 4 & $8.3 \%$ \\
\cline { 2 - 9 } & $\mathrm{A}$ & 10 & $40.0 \%$ & 4 & $17.4 \%$ & 14 & $29.2 \%$ \\
\cline { 2 - 9 } & NAND & 4 & $16.0 \%$ & 7 & $30.4 \%$ & 11 & $22.9 \%$ \\
\hline
\end{tabular}


Could Cll Approach be a Remedy for Tripoli Secondary Students Speaking Skills?

\begin{tabular}{|l|l|l|l|l|l|l|l|}
\hline \multirow{5}{*}{} & DA & 3 & $12.0 \%$ & 9 & $39.1 \%$ & 12 & $25.0 \%$ \\
\cline { 2 - 8 } & SD & 4 & $16.0 \%$ & 3 & $13.0 \%$ & 7 & $14.6 \%$ \\
\cline { 2 - 8 } & Total & 25 & $100.0 \%$ & 23 & $100.0 \%$ & 48 & $100.0 \%$ \\
\hline \multirow{5}{*}{ Private } & SA & 14 & $51.9 \%$ & 9 & $37.5 \%$ & 23 & $45.1 \%$ \\
\cline { 2 - 8 } & A & 10 & $37.0 \%$ & 5 & $20.8 \%$ & 15 & $29.4 \%$ \\
\cline { 2 - 8 } & NAND & 2 & $7.4 \%$ & 3 & $12.5 \%$ & 5 & $9.8 \%$ \\
\cline { 2 - 8 } & DA & 1 & $3.7 \%$ & 3 & $12.5 \%$ & 4 & $7.8 \%$ \\
\cline { 2 - 8 } & SD & 0 & & 4 & $16.7 \%$ & 4 & $7.8 \%$ \\
\cline { 2 - 8 } & Total & 27 & $100.0 \%$ & 24 & $100.0 \%$ & 51 & $100.0 \%$ \\
\hline \multirow{5}{*}{ Total } & SA & 18 & $34.6 \%$ & 9 & $19.1 \%$ & 27 & $27.3 \%$ \\
\cline { 2 - 8 } & A & 14 & $26.9 \%$ & 9 & $19.1 \%$ & 23 & $23.2 \%$ \\
\cline { 2 - 8 } & NAND & 12 & $23.1 \%$ & 10 & $21.3 \%$ & 22 & $22.2 \%$ \\
\cline { 2 - 8 } & DA & 4 & $7.7 \%$ & 12 & $25.5 \%$ & 16 & $16.2 \%$ \\
\cline { 2 - 8 } & SD & $4.7 \%$ & 7 & $14.9 \%$ & 11 & $11.1 \%$ \\
\cline { 2 - 8 } & Total & 52 & $100.0 \%$ & 47 & $100.0 \%$ & 99 & $100.0 \%$ \\
\hline
\end{tabular}

Table 12 of the anxiety posttest revealed that $56 \%$ of the participants in the public experimental group strongly agree and agree respectively with that it wouldn't bother them at all to take more foreign language classes, $16 \%$ of the participants neither agree nor disagree with the statement, and $28 \%$ of the participants disagree and strongly disagree respectively. While in the control group, $17.4 \%$ of the participants agree and strongly ag with the same statement, $30.4 \%$ of the participants neither agree nor disagree, and $52 \%$ disagree with the statement. Whereas $88.9 \%$ of the participants in the private experimental group agree and strongly agree with the same tested statement, $7.4 \%$ neither agree nor disagree with the statement, and $3.7 \%$ of the participants disagree with it. While in the control group, $58.3 \%$ of the participants agree with the same statement, $12.5 \%$ neither agree nor disagree, and $29.2 \%$ disagree with it. Such differences in the results between the control and experimental groups indicate that anxiety has dramatically decreased in the experimental groups after implementing CLL, and the participants had no fears and were more confident to take more foreign language courses especially the private school participants.

Table13. Q6. Anxiety pre test

\begin{tabular}{|c|c|c|c|c|c|c|c|}
\hline \multirow[t]{3}{*}{ School } & \multirow[t]{3}{*}{ Q6 } & \multicolumn{4}{|c|}{ Group } & \multicolumn{2}{|c|}{ Total } \\
\hline & & \multicolumn{2}{|c|}{ Experimental } & \multicolumn{2}{|c|}{ Control } & & \\
\hline & & $\mathrm{N}$ & $\%$ & $\mathrm{~N}$ & $\%$ & $\mathrm{~N}$ & $\%$ \\
\hline \multirow[t]{6}{*}{ Public } & SA & 1 & $3.8 \%$ & 0 & & 1 & $1.7 \%$ \\
\hline & A & 5 & $19.2 \%$ & 9 & $28.1 \%$ & 14 & $24.1 \%$ \\
\hline & NAND & 7 & $26.9 \%$ & 10 & $31.3 \%$ & 17 & $29.3 \%$ \\
\hline & DA & 11 & $42.3 \%$ & 11 & $34.4 \%$ & 22 & $37.9 \%$ \\
\hline & SD & 2 & $7.7 \%$ & 2 & $6.3 \%$ & 4 & $6.9 \%$ \\
\hline & Total & 26 & $100.0 \%$ & 32 & $100.0 \%$ & 58 & $100.0 \%$ \\
\hline \multirow[t]{6}{*}{ Private } & SA & 7 & $25.9 \%$ & 9 & $28.1 \%$ & 16 & $27.1 \%$ \\
\hline & A & 4 & $14.8 \%$ & 1 & $3.1 \%$ & 5 & $8.5 \%$ \\
\hline & NAND & 8 & $29.6 \%$ & 10 & $31.3 \%$ & 18 & $30.5 \%$ \\
\hline & DA & 3 & $11.1 \%$ & 12 & $37.5 \%$ & 15 & $25.4 \%$ \\
\hline & SD & 5 & $18.5 \%$ & 0 & & 5 & $8.5 \%$ \\
\hline & Total & 27 & $100.0 \%$ & 32 & $100.0 \%$ & 59 & $100.0 \%$ \\
\hline \multirow[t]{6}{*}{ Total } & SA & 8 & $15.1 \%$ & 9 & $14.1 \%$ & 17 & $14.5 \%$ \\
\hline & A & 9 & $17.0 \%$ & 10 & $15.6 \%$ & 19 & $16.2 \%$ \\
\hline & NAND & 15 & $28.3 \%$ & 20 & $31.3 \%$ & 35 & $29.9 \%$ \\
\hline & DA & 14 & $26.4 \%$ & 23 & $35.9 \%$ & 37 & $31.6 \%$ \\
\hline & SD & 7 & $13.2 \%$ & 2 & $3.1 \%$ & 9 & $7.7 \%$ \\
\hline & Total & 53 & $100.0 \%$ & 64 & $100.0 \%$ & 117 & $100.0 \%$ \\
\hline
\end{tabular}

Table 13 revealed that $25.8 \%$ of the public school participants strongly agree and agree that during foreign language class, they find themselves thinking about things that have nothing to do with the course, $29.3 \%$ neither agree nor disagree, and $44.8 \%$ disagree and strongly disagree respectively with the statement. Whereas $35.6 \%$ of the private school participants agree and strongly disagree with the same statement, $30.5 \%$ neither agree nor disagree, and 33.9\% disagree and strongly disagree with the statement. Such results indicate that the majority of the participants in the public and private schools are irresponsible towards the EFL and have no motivation towards learning a new language with high anxiety that make them unable to focus completely in the language learning session. 
Table14. Q6. Anxiety post test results

\begin{tabular}{|c|c|c|c|c|c|c|c|}
\hline \multirow[t]{3}{*}{ School } & \multirow[t]{3}{*}{ Q6 } & \multicolumn{4}{|c|}{ Group } & \multicolumn{2}{|c|}{ Total } \\
\hline & & \multicolumn{2}{|c|}{ Experimental } & \multicolumn{2}{|c|}{ Control } & & \\
\hline & & $\mathrm{N}$ & $\%$ & $\mathrm{~N}$ & $\%$ & $\mathrm{~N}$ & $\%$ \\
\hline \multirow{6}{*}{ Public } & SA & 0 & & 4 & $17.4 \%$ & 4 & $8.2 \%$ \\
\hline & $\mathrm{A}$ & 0 & & 16 & $69.6 \%$ & 16 & $32.7 \%$ \\
\hline & NAND & 0 & & 3 & $13.0 \%$ & 3 & $6.1 \%$ \\
\hline & $\mathrm{DA}$ & 12 & $46.2 \%$ & 0 & & 12 & $24.5 \%$ \\
\hline & SD & 14 & $53.8 \%$ & 0 & & 14 & $28.6 \%$ \\
\hline & Total & 26 & $100.0 \%$ & 23 & $100.0 \%$ & 49 & $100.0 \%$ \\
\hline \multirow[t]{6}{*}{ Private } & $\mathrm{SA}$ & 0 & & 8 & $33.3 \%$ & 8 & $15.7 \%$ \\
\hline & $\mathrm{A}$ & 0 & & 5 & $20.8 \%$ & 5 & $9.8 \%$ \\
\hline & NAND & 1 & $3.7 \%$ & 6 & $25.0 \%$ & 7 & $13.7 \%$ \\
\hline & DA & 10 & $37.0 \%$ & 3 & $12.5 \%$ & 13 & $25.5 \%$ \\
\hline & SD & 16 & $59.3 \%$ & 2 & $8.3 \%$ & 18 & $35.3 \%$ \\
\hline & Total & 27 & $100.0 \%$ & 24 & $100.0 \%$ & 51 & $100.0 \%$ \\
\hline \multirow[t]{6}{*}{ Total } & $\mathrm{SA}$ & 0 & & 12 & $25.5 \%$ & 12 & $12.0 \%$ \\
\hline & $\mathrm{A}$ & 0 & & 21 & $44.7 \%$ & 21 & $21.0 \%$ \\
\hline & NAND & 1 & $1.9 \%$ & 9 & $19.1 \%$ & 10 & $10.0 \%$ \\
\hline & $\mathrm{DA}$ & 22 & $41.5 \%$ & 3 & $6.4 \%$ & 25 & $25.0 \%$ \\
\hline & SD & 30 & $56.6 \%$ & 2 & $4.3 \%$ & 32 & $32.0 \%$ \\
\hline & Total & 53 & $100.0 \%$ & 47 & $100.0 \%$ & 100 & $100.0 \%$ \\
\hline
\end{tabular}

Table 14 of the anxiety posttest showed that $0 \%$ of the participants in the public experimental group strongly agree and agree with that during foreign language class, they find themselves thinking about things that have nothing to do with the course, $0 \%$ of the participants neither agree nor disagree with the statement, and $100 \%$ of the participants disagree and strongly disagree respectively. While in the control group, $87 \%$ of the participants agree and strongly agree with the same statement, $13 \%$ of the participants neither agree nor disagree, and $0 \%$ disagree with the statement.

Whereas $0 \%$ of the participants in the private experimental group agree and strongly agree with the same tested statement, 3.7\% neither agree nor disagree with the statement, and $96.3 \%$ of the participants disagree with it. While in the control group, $54.1 \%$ of the participants agree with the same statement, 25\% neither agree nor disagree, and 20.8\% disagree with it. Such differences in the results between the control and experimental groups indicate that anxiety has dramatically decreased in the experimental groups and almost all the participants have more responsibility and self confidence towards learning foreign language.

Table15. Q7. Anxiety pre test

\begin{tabular}{|c|c|c|c|c|c|c|c|}
\hline \multirow[t]{3}{*}{ School } & \multirow[t]{3}{*}{ Q7 } & \multicolumn{4}{|c|}{ Group } & \multicolumn{2}{|c|}{ Total } \\
\hline & & \multicolumn{2}{|c|}{ Experimental } & \multicolumn{2}{|c|}{ Control } & & \\
\hline & & $\mathrm{N}$ & $\%$ & $\mathrm{~N}$ & $\%$ & $\mathrm{~N}$ & $\%$ \\
\hline \multirow[t]{6}{*}{ Public } & SA & 5 & $19.2 \%$ & 3 & $9.4 \%$ & 8 & $13.8 \%$ \\
\hline & $\mathrm{A}$ & 8 & $30.8 \%$ & 10 & $31.3 \%$ & 18 & $31.0 \%$ \\
\hline & NAND & 9 & $34.6 \%$ & 7 & $21.9 \%$ & 16 & $27.6 \%$ \\
\hline & DA & 2 & $7.7 \%$ & 4 & $12.5 \%$ & 6 & $10.3 \%$ \\
\hline & SD & 2 & $7.7 \%$ & 8 & $25.0 \%$ & 10 & $17.2 \%$ \\
\hline & Total & 26 & $100.0 \%$ & 32 & $100.0 \%$ & 58 & $100.0 \%$ \\
\hline \multirow[t]{6}{*}{ Private } & SA & 4 & $14.8 \%$ & 2 & $6.3 \%$ & 6 & $10.2 \%$ \\
\hline & A & 5 & $18.5 \%$ & 2 & $6.3 \%$ & 7 & $11.9 \%$ \\
\hline & NAND & 10 & $37.0 \%$ & 5 & $15.6 \%$ & 15 & $25.4 \%$ \\
\hline & DA & 8 & $29.6 \%$ & 20 & $62.5 \%$ & 28 & $47.5 \%$ \\
\hline & SD & 0 & & 3 & $9.4 \%$ & 3 & $5.1 \%$ \\
\hline & Total & 27 & $100.0 \%$ & 32 & $100.0 \%$ & 59 & $100.0 \%$ \\
\hline \multirow[t]{6}{*}{ Total } & SA & 9 & $17.0 \%$ & 5 & $7.8 \%$ & 14 & $12.0 \%$ \\
\hline & $\mathrm{A}$ & 13 & $24.5 \%$ & 12 & $18.8 \%$ & 25 & $21.4 \%$ \\
\hline & NAND & 19 & $35.8 \%$ & 12 & $18.8 \%$ & 31 & $26.5 \%$ \\
\hline & DA & 10 & $18.9 \%$ & 24 & $37.5 \%$ & 34 & $29.1 \%$ \\
\hline & SD & 2 & $3.8 \%$ & 11 & $17.2 \%$ & 13 & $11.1 \%$ \\
\hline & Total & 53 & $100.0 \%$ & 64 & $100.0 \%$ & 117 & $100.0 \%$ \\
\hline
\end{tabular}

Table 15 revealed that $44.8 \%$ of the public school participants strongly agree and agree that they keep thinking that the other students are better at languages than they are $27.6 \%$ neither agree nor disagree 
and $27.5 \%$ disagree and strongly disagree respectively with the statement. Whereas $22.1 \%$ of the private school participants agree and strongly disagree with the same statement, $25.4 \%$ neither agree nor disagree, and $52.6 \%$ disagree and strongly disagree with the statement. Such results indicate that the majority of participants in the public school have more anxiety, fear of negative evaluation and lower self confidence than the participants in the private schools.

Table16. Q7. Anxiety post test results

\begin{tabular}{|c|c|c|c|c|c|c|c|}
\hline \multirow[t]{3}{*}{ School } & \multirow[t]{3}{*}{ Q7 } & \multicolumn{4}{|c|}{ Group } & \multicolumn{2}{|c|}{ Total } \\
\hline & & \multicolumn{2}{|c|}{ Experimental } & \multicolumn{2}{|c|}{ Control } & & \\
\hline & & $\mathrm{N}$ & $\%$ & $\mathrm{~N}$ & $\%$ & $\mathrm{~N}$ & $\%$ \\
\hline \multirow[t]{6}{*}{ Public } & SA & 0 & & 11 & $47.8 \%$ & 11 & $22.4 \%$ \\
\hline & A & 1 & $3.8 \%$ & 12 & $52.2 \%$ & 13 & $26.5 \%$ \\
\hline & NAND & 6 & $23.1 \%$ & 0 & & 6 & $12.2 \%$ \\
\hline & DA & 9 & $34.6 \%$ & 0 & & 9 & $18.4 \%$ \\
\hline & SD & 10 & $38.5 \%$ & 0 & & 10 & $20.4 \%$ \\
\hline & Total & 26 & $100.0 \%$ & 23 & $100.0 \%$ & 49 & $100.0 \%$ \\
\hline \multirow[t]{6}{*}{ Private } & SA & 0 & & 1 & $4.2 \%$ & 1 & $2.0 \%$ \\
\hline & A & 0 & & 5 & $20.8 \%$ & 5 & $9.8 \%$ \\
\hline & NAND & 1 & $3.7 \%$ & 9 & $37.5 \%$ & 10 & $19.6 \%$ \\
\hline & $\mathrm{DA}$ & 9 & $33.3 \%$ & 8 & $33.3 \%$ & 17 & $33.3 \%$ \\
\hline & SD & 17 & $63.0 \%$ & 1 & $4.2 \%$ & 18 & $35.3 \%$ \\
\hline & Total & 27 & $100.0 \%$ & 24 & $100.0 \%$ & 51 & $100.0 \%$ \\
\hline \multirow[t]{6}{*}{ Total } & $\mathrm{SA}$ & 0 & & 12 & $25.5 \%$ & 12 & $12.0 \%$ \\
\hline & A & 1 & $1.9 \%$ & 17 & $36.2 \%$ & 18 & $18.0 \%$ \\
\hline & NAND & 7 & $13.2 \%$ & 9 & $19.1 \%$ & 16 & $16.0 \%$ \\
\hline & DA & 18 & $34.0 \%$ & 8 & $17.0 \%$ & 26 & $26.0 \%$ \\
\hline & SD & 27 & $50.9 \%$ & 1 & $2.1 \%$ & 28 & $28.0 \%$ \\
\hline & Total & 53 & $100.0 \%$ & 47 & $100.0 \%$ & 100 & $100.0 \%$ \\
\hline
\end{tabular}

Table 16 of the anxiety posttest showed that $3.8 \%$ of the participants in the public experimental group agree with that they keep thinking that the other students are better at languages than they are, $23.1 \%$ of the participants neither agree nor disagree with the statement, and $73.1 \%$ of the participants disagree and strongly disagree respectively. While in the public control group, $100 \%$ of the participants agree and strongly agree with the same statement, $0 \%$ of the participants neither agree nor disagree, and $0 \%$ disagree with the statement. Whereas $0 \%$ of the participants in the private experimental group agree and strongly agree with the same statement, $3.7 \%$ neither agree nor disagree with the statement, and $96.3 \%$ of the participants disagree with it. While in the private control group, $25 \%$ of the participants agree with the same tested statement, $37.5 \%$ neither agree nor disagree, and $37.5 \%$ disagree with it. Such differences in the results between the control and experimental groups indicate that anxiety has dramatically decreased in the experimental groups and almost all the participants had no fear of negative evaluation from their peers and more self confidence towards the foreign language. Noting that the private experimental group outperformed the public experimental group after conducting CLL.

Table17. Q8. Anxiety pre test

\begin{tabular}{|c|c|c|c|c|c|c|c|}
\hline \multirow[t]{3}{*}{ School } & \multirow[t]{3}{*}{ Q8 } & \multicolumn{4}{|c|}{ Group } & \multicolumn{2}{|c|}{ Total } \\
\hline & & \multicolumn{2}{|c|}{ Experimental } & \multicolumn{2}{|c|}{ Control } & & \\
\hline & & $\mathrm{N}$ & $\%$ & $\mathrm{~N}$ & $\%$ & $\mathrm{~N}$ & $\%$ \\
\hline \multirow[t]{6}{*}{ Public } & SA & 4 & $15.4 \%$ & 3 & $9.4 \%$ & 7 & $12.1 \%$ \\
\hline & A & 10 & $38.5 \%$ & 7 & $21.9 \%$ & 17 & $29.3 \%$ \\
\hline & NAND & 10 & $38.5 \%$ & 15 & $46.9 \%$ & 25 & $43.1 \%$ \\
\hline & DA & 2 & $7.7 \%$ & 5 & $15.6 \%$ & 7 & $12.1 \%$ \\
\hline & SD & 0 & & 2 & $6.3 \%$ & 2 & $3.4 \%$ \\
\hline & Total & 26 & $100.0 \%$ & 32 & $100.0 \%$ & 58 & $100.0 \%$ \\
\hline \multirow[t]{6}{*}{ Private } & SA & 8 & $29.6 \%$ & 4 & $12.5 \%$ & 12 & $20.3 \%$ \\
\hline & A & 5 & $18.5 \%$ & 3 & $9.4 \%$ & 8 & $13.6 \%$ \\
\hline & NAND & 6 & $22.2 \%$ & 14 & $43.8 \%$ & 20 & $33.9 \%$ \\
\hline & DA & 5 & $18.5 \%$ & 8 & $25.0 \%$ & 13 & $22.0 \%$ \\
\hline & SD & 3 & $11.1 \%$ & 3 & $9.4 \%$ & 6 & $10.2 \%$ \\
\hline & Total & 27 & $100.0 \%$ & 32 & $100.0 \%$ & 59 & $100.0 \%$ \\
\hline \multirow[t]{2}{*}{ Total } & SA & 12 & $22.6 \%$ & 7 & $10.9 \%$ & 19 & $16.2 \%$ \\
\hline & A & 15 & $28.3 \%$ & 10 & $15.6 \%$ & 25 & $21.4 \%$ \\
\hline
\end{tabular}




\begin{tabular}{|l|l|l|l|l|l|l|l|}
\hline \multirow{2}{*}{} & NAND & 16 & $30.2 \%$ & 29 & $45.3 \%$ & 45 & $38.5 \%$ \\
\cline { 2 - 8 } & DA & 7 & $13.2 \%$ & 13 & $20.3 \%$ & 20 & $17.1 \%$ \\
\cline { 2 - 9 } & SD & 3 & $5.7 \%$ & 5 & $7.8 \%$ & 8 & $6.8 \%$ \\
\cline { 2 - 8 } & Total & 53 & $100.0 \%$ & 64 & $100.0 \%$ & 117 & $100.0 \%$ \\
\hline
\end{tabular}

Table 17 displayed $41.4 \%$ of the public school participants strongly agree and agree that they are usually at ease during tests in their foreign language class, $43.1 \%$ neither agree nor disagree, and $15.5 \%$ disagree and strongly disagree respectively with the statement. Whereas $33.9 \%$ of the private school participants agree and strongly disagree with the same statement, $33.9 \%$ neither agree nor disagree, and $32.2 \%$ disagree and strongly disagree with the statement. Such results indicate that the majority of the participants in the public and private schools are irresponsible towards the EFL especially doing tests and have no motivation towards learning a new language with a moderate level of anxiety.

Table18. Q8. Anxiety post test results

\begin{tabular}{|c|c|c|c|c|c|c|c|}
\hline \multirow[t]{3}{*}{ School } & \multirow[t]{3}{*}{ Q8 } & \multicolumn{4}{|c|}{ Group } & \multicolumn{2}{|c|}{ Total } \\
\hline & & \multicolumn{2}{|c|}{ Experimental } & \multicolumn{2}{|c|}{ Control } & & \\
\hline & & $\mathrm{N}$ & $\%$ & $\mathrm{~N}$ & $\%$ & $\mathrm{~N}$ & $\%$ \\
\hline \multirow[t]{6}{*}{ Public } & SA & 0 & $0 \%$ & 0 & $0 \%$ & 0 & $0 \%$ \\
\hline & A & 12 & $46.2 \%$ & 0 & & 12 & $24.5 \%$ \\
\hline & NAND & 6 & $23.1 \%$ & 1 & $4.3 \%$ & 7 & $14.3 \%$ \\
\hline & DA & 7 & $26.9 \%$ & 16 & $69.6 \%$ & 23 & $46.9 \%$ \\
\hline & SD & 1 & $3.8 \%$ & 6 & $26.1 \%$ & 7 & $14.3 \%$ \\
\hline & Total & 26 & $100.0 \%$ & 23 & $100.0 \%$ & 49 & $100.0 \%$ \\
\hline \multirow[t]{6}{*}{ Private } & $\mathrm{SA}$ & 0 & & 3 & $12.5 \%$ & 3 & $5.9 \%$ \\
\hline & $\mathrm{A}$ & 8 & $29.6 \%$ & 6 & $25.0 \%$ & 14 & $27.5 \%$ \\
\hline & NAND & 15 & $55.6 \%$ & 9 & $37.5 \%$ & 24 & $47.1 \%$ \\
\hline & $\mathrm{DA}$ & 3 & $11.1 \%$ & 4 & $16.7 \%$ & 7 & $13.7 \%$ \\
\hline & SD & 1 & $3.7 \%$ & 2 & $8.3 \%$ & 3 & $5.9 \%$ \\
\hline & Total & 27 & $100.0 \%$ & 24 & $100.0 \%$ & 51 & $100.0 \%$ \\
\hline \multirow[t]{6}{*}{ Total } & SA & 0 & $0 \%$ & 3 & $6.4 \%$ & 3 & $3.0 \%$ \\
\hline & $\mathrm{A}$ & 20 & $37.7 \%$ & 6 & $12.8 \%$ & 26 & $26.0 \%$ \\
\hline & NAND & 21 & $39.6 \%$ & 10 & $21.3 \%$ & 31 & $31.0 \%$ \\
\hline & $\mathrm{DA}$ & 10 & $18.9 \%$ & 20 & $42.6 \%$ & 30 & $30.0 \%$ \\
\hline & SD & 2 & $3.8 \%$ & 8 & $17.0 \%$ & 10 & $10.0 \%$ \\
\hline & Total & 53 & $100.0 \%$ & 47 & $100.0 \%$ & 100 & $100.0 \%$ \\
\hline
\end{tabular}

Table 18 of the anxiety posttest revealed that $46.2 \%$ of the participants in the public experimental group agree with that they are usually at ease during tests in their foreign language class, $23.1 \%$ of the participants neither agree nor disagree with the statement, and $30.7 \%$ of the participants disagree and strongly disagree respectively. While in the public control group, $0 \%$ of the participants agree and strongly agree with the same statement, $4.3 \%$ of the participants neither agree nor disagree, and $95.7 \%$ disagree and strongly disagree with the statement. Whereas $29.6 \%$ of the participants in the private experimental group agree with the same statement, $55.6 \%$ neither agree nor disagree with the statement, and $14.8 \%$ of the participants disagree with it. While in the private control group, $37.5 \%$ of the participants agree with the same statement, $37.5 \%$ neither agree nor disagree, and $25 \%$ disagree with it. Such differences in the results between the control and experimental groups indicate that the majority of the participants in the public and private schools have low anxiety level and a good number of them are still irresponsible towards the EFL especially during tests.

Table19. Q9. Anxiety pre test

\begin{tabular}{|c|c|c|c|c|c|c|c|}
\hline \multirow[t]{3}{*}{ School } & Q9 & \multicolumn{4}{|c|}{ Group } & \multicolumn{2}{|c|}{ Total } \\
\hline & & \multicolumn{2}{|c|}{ Experimental } & \multicolumn{2}{|c|}{ Control } & & \\
\hline & & $\mathrm{N}$ & $\%$ & $\mathrm{~N}$ & $\%$ & $\mathrm{~N}$ & $\%$ \\
\hline \multirow[t]{6}{*}{ Public } & SA & 3 & $11.5 \%$ & 4 & $12.5 \%$ & 7 & $12.1 \%$ \\
\hline & A & 9 & $34.6 \%$ & 11 & $34.4 \%$ & 20 & $34.5 \%$ \\
\hline & NAND & 3 & $11.5 \%$ & 7 & $21.9 \%$ & 10 & $17.2 \%$ \\
\hline & DA & 10 & $38.5 \%$ & 4 & $12.5 \%$ & 14 & $24.1 \%$ \\
\hline & SD & 1 & $3.8 \%$ & 6 & $18.8 \%$ & 7 & $12.1 \%$ \\
\hline & Total & 26 & $100.0 \%$ & 32 & $100.0 \%$ & 58 & $100.0 \%$ \\
\hline \multirow[t]{3}{*}{ Private } & $\mathrm{SA}$ & 7 & $25.9 \%$ & 5 & $15.6 \%$ & 12 & $20.3 \%$ \\
\hline & A & 5 & $18.5 \%$ & 3 & $9.4 \%$ & 8 & $13.6 \%$ \\
\hline & NAND & 3 & $11.1 \%$ & 4 & $12.5 \%$ & 7 & $11.9 \%$ \\
\hline
\end{tabular}


Could Cll Approach be a Remedy for Tripoli Secondary Students Speaking Skills?

\begin{tabular}{|l|l|l|l|l|l|l|l|}
\hline \multirow{5}{*}{} & DA & 7 & $25.9 \%$ & 7 & $21.9 \%$ & 14 & $23.7 \%$ \\
\cline { 2 - 9 } & SD & 5 & $18.5 \%$ & 13 & $40.6 \%$ & 18 & $30.5 \%$ \\
\cline { 2 - 8 } & Total & 27 & $100.0 \%$ & 32 & $100.0 \%$ & 59 & $100.0 \%$ \\
\hline \multirow{4}{*}{ Sotal } & SA & 10 & $18.9 \%$ & 9 & $14.1 \%$ & 19 & $16.2 \%$ \\
\cline { 2 - 8 } & A & 14 & $26.4 \%$ & 14 & $21.9 \%$ & 28 & $23.9 \%$ \\
\cline { 2 - 8 } & NAND & 6 & $11.3 \%$ & 11 & $17.2 \%$ & 17 & $14.5 \%$ \\
\cline { 2 - 8 } & DA & 17 & $32.1 \%$ & 11 & $17.2 \%$ & 28 & $23.9 \%$ \\
\cline { 2 - 8 } & SD & 6 & $11.3 \%$ & 19 & $29.7 \%$ & 25 & $21.4 \%$ \\
\cline { 2 - 8 } & Total & 53 & $100.0 \%$ & 64 & $100.0 \%$ & 117 & $100.0 \%$ \\
\hline
\end{tabular}

Table 19 disclosed that $46.6 \%$ of the public school participants strongly agree and agree that they start to panic when they have to speak without preparation in foreign language class, $17.2 \%$ neither agree nor disagree and $36.2 \%$ disagree and strongly disagree respectively with the statement. Whereas $33.9 \%$ of the private school participants agree and strongly disagree with the same statement, $11.9 \%$ neither agree nor disagree, and 54.2\% disagree and strongly disagree with the statement. Such results indicate that the majority of the public participants got more of moderate anxiety, were more irresponsible and lower self confidence towards the EFL than the participants of the private school.

Table20. Q9. Anxiety post test results

\begin{tabular}{|c|c|c|c|c|c|c|c|}
\hline \multirow[t]{3}{*}{ School } & \multirow[t]{3}{*}{ Q9 } & \multicolumn{4}{|c|}{ Group } & \multicolumn{2}{|c|}{ Total } \\
\hline & & \multicolumn{2}{|c|}{ Experimental } & \multicolumn{2}{|c|}{ Control } & & \\
\hline & & $\mathrm{N}$ & $\%$ & $\mathrm{~N}$ & $\%$ & $\mathrm{~N}$ & $\%$ \\
\hline \multirow[t]{6}{*}{ Public } & SA & 0 & & 13 & $56.5 \%$ & 13 & $26.5 \%$ \\
\hline & A & 0 & & 9 & $39.1 \%$ & 9 & $18.4 \%$ \\
\hline & NAND & 4 & $15.4 \%$ & 1 & $4.3 \%$ & 5 & $10.2 \%$ \\
\hline & $\mathrm{DA}$ & 16 & $61.5 \%$ & 0 & & 16 & $32.7 \%$ \\
\hline & SD & 6 & $23.1 \%$ & 0 & & 6 & $12.2 \%$ \\
\hline & Total & 26 & $100.0 \%$ & 23 & $100.0 \%$ & 49 & $100.0 \%$ \\
\hline \multirow[t]{6}{*}{ Private } & SA & 0 & & 4 & $16.7 \%$ & 4 & $7.8 \%$ \\
\hline & A & 1 & $3.7 \%$ & 4 & $16.7 \%$ & 5 & $9.8 \%$ \\
\hline & NAND & 1 & $3.7 \%$ & 7 & $29.2 \%$ & 8 & $15.7 \%$ \\
\hline & DA & 21 & $77.8 \%$ & 7 & $29.2 \%$ & 28 & $54.9 \%$ \\
\hline & SD & 4 & $14.8 \%$ & 2 & $8.3 \%$ & 6 & $11.8 \%$ \\
\hline & Total & 27 & $100.0 \%$ & 24 & $100.0 \%$ & 51 & $100.0 \%$ \\
\hline \multirow[t]{6}{*}{ Total } & SA & 0 & & 17 & $36.2 \%$ & 17 & $17.0 \%$ \\
\hline & $\mathrm{A}$ & 1 & $1.9 \%$ & 13 & $27.7 \%$ & 14 & $14.0 \%$ \\
\hline & NAND & 5 & $9.4 \%$ & 8 & $17.0 \%$ & 13 & $13.0 \%$ \\
\hline & DA & 37 & $69.8 \%$ & 7 & $14.9 \%$ & 44 & $44.0 \%$ \\
\hline & SD & 10 & $18.9 \%$ & 2 & $4.3 \%$ & 12 & $12.0 \%$ \\
\hline & Total & 53 & $100.0 \%$ & 47 & $100.0 \%$ & 100 & $100.0 \%$ \\
\hline
\end{tabular}

Table 20 of the anxiety posttest presented $0 \%$ of the participants in the public experimental group strongly agree and agree with that they start to panic when they have to speak without preparation in foreign language class, $15.4 \%$ of the participants neither agree nor disagree with the statement, and $84.6 \%$ of the participants disagree and strongly disagree respectively. While in the control group, $95.7 \%$ of the participants agree and strongly with the same statement, $4.3 \%$ of the participants neither agree nor disagree, and $0 \%$ disagree with the statement. Whereas $3.7 \%$ of the participants in the private experimental group agree and strongly agree with the same tested statement, $3.7 \%$ neither agree nor disagree with the statement, and $92.6 \%$ of the participants disagree with it. While in the control group, $33.4 \%$ of the participants agree with the same statement, $29.2 \%$ neither agree nor disagree, and $37.5 \%$ disagree with it. Such differences in the results between the control and experimental groups indicate that although anxiety has dramatically decreased in the experimental groups and almost all the participants had better self confidence towards the English foreign language we can notice through statistics that a good number of public school participants is still irresponsible towards the EFL learning.

Table21. Q10. Anxiety pre test

\begin{tabular}{|l|l|l|l|l|l|l|l|}
\hline \multirow{3}{*}{ School } & Q10 & \multicolumn{3}{|l|}{ Group } & \multicolumn{2}{l|}{ Total } \\
\cline { 2 - 9 } & & \multicolumn{3}{|l|}{ Experimental } & Control & & \\
& & $\mathrm{N}$ & $\%$ & $\mathrm{~N}$ & $\%$ & $\mathrm{~N}$ & $\%$ \\
\hline \multirow{3}{*}{ Public } & SA & 10 & $38.5 \%$ & 7 & $21.9 \%$ & 17 & $29.3 \%$ \\
\cline { 2 - 9 } & $\mathrm{A}$ & 12 & $46.2 \%$ & 11 & $34.4 \%$ & 23 & $39.7 \%$ \\
\cline { 2 - 9 } & NAND & 0 & & 8 & $25.0 \%$ & 8 & $13.8 \%$ \\
\hline
\end{tabular}


Could Cll Approach be a Remedy for Tripoli Secondary Students Speaking Skills?

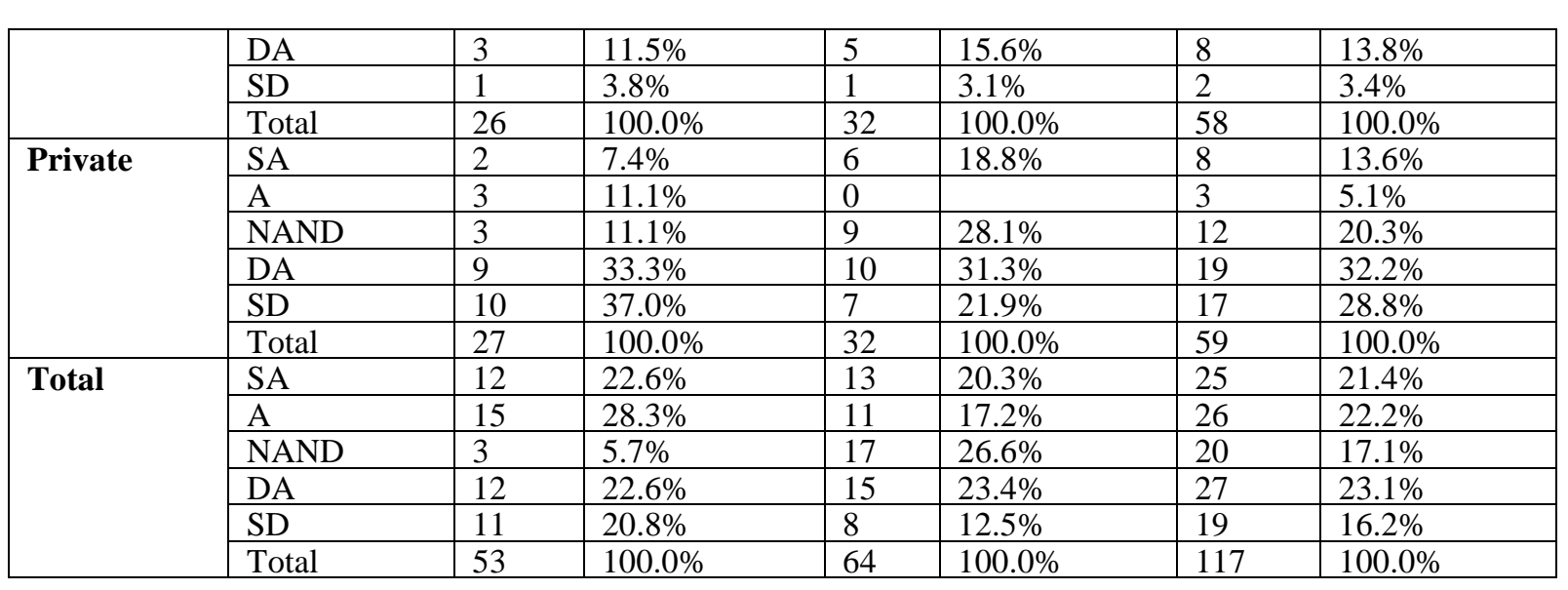

Table 21 revealed that $69 \%$ of the public school participants agree that they worry about the consequences of failing their foreign language class, $13.8 \%$ neither agree nor disagree, and $17.2 \%$ rticipants agree and strongly disagree with the same statement, $20.3 \%$ neither agree nor disagree, and $61 \%$ disagree and strongly disagree with the statement. Such results indicate that the majority of the participants in the public school have high anxiety towards the consequences of failing the EFL which can be explained responsibility toward the EFL learning, while the majority of the participants in the private school have low anxiety level toward the consequences of failing the class which can be explained as irresponsibility towards the EFL learning.

Table22. Q10. Anxiety post test results

\begin{tabular}{|c|c|c|c|c|c|c|c|}
\hline \multirow[t]{3}{*}{ School } & \multirow[t]{3}{*}{ Q10 } & \multicolumn{4}{|c|}{ Group } & \multicolumn{2}{|c|}{ Total } \\
\hline & & \multicolumn{2}{|c|}{ Experimental } & \multicolumn{2}{|c|}{ Control } & & \\
\hline & & $\mathrm{N}$ & $\%$ & $\mathrm{~N}$ & $\%$ & $\mathrm{~N}$ & $\%$ \\
\hline \multirow[t]{6}{*}{ Public } & SA & 0 & & 4 & $17.4 \%$ & 4 & $8.2 \%$ \\
\hline & A & 3 & $11.5 \%$ & 16 & $69.6 \%$ & 19 & $38.8 \%$ \\
\hline & NAND & 7 & $26.9 \%$ & 3 & $13.0 \%$ & 10 & $20.4 \%$ \\
\hline & DA & 14 & $53.8 \%$ & 0 & & 14 & $28.6 \%$ \\
\hline & SD & 2 & $7.7 \%$ & 0 & & 2 & $4.1 \%$ \\
\hline & Total & 26 & $100.0 \%$ & 23 & $100.0 \%$ & 49 & $100.0 \%$ \\
\hline \multirow[t]{6}{*}{ Private } & SA & 0 & & 3 & $12.5 \%$ & 3 & $5.9 \%$ \\
\hline & $\mathrm{A}$ & 6 & $22.2 \%$ & 1 & $4.2 \%$ & 7 & $13.7 \%$ \\
\hline & NAND & 11 & $40.7 \%$ & 8 & $33.3 \%$ & 19 & $37.3 \%$ \\
\hline & DA & 10 & $37.0 \%$ & 8 & $33.3 \%$ & 18 & $35.3 \%$ \\
\hline & SD & 0 & & 4 & $16.7 \%$ & 4 & $7.8 \%$ \\
\hline & Total & 27 & $100.0 \%$ & 24 & $100.0 \%$ & 51 & $100.0 \%$ \\
\hline \multirow[t]{6}{*}{ Total } & SA & 0 & & 7 & $14.9 \%$ & 7 & $7.0 \%$ \\
\hline & $\mathrm{A}$ & 9 & $17.0 \%$ & 17 & $36.2 \%$ & 26 & $26.0 \%$ \\
\hline & NAND & 18 & $34.0 \%$ & 11 & $23.4 \%$ & 29 & $29.0 \%$ \\
\hline & DA & 24 & $45.3 \%$ & 8 & $17.0 \%$ & 32 & $32.0 \%$ \\
\hline & SD & 2 & $3.8 \%$ & 4 & $8.5 \%$ & 6 & $6.0 \%$ \\
\hline & Total & 53 & $100.0 \%$ & 47 & $100.0 \%$ & 100 & $100.0 \%$ \\
\hline
\end{tabular}

Table 22 of the anxiety posttest revealed that $11.5 \%$ of the participants in the public experimental group agree with that they worry about the consequences of failing their foreign language class, $26.9 \%$ of the participants neither agree nor disagree with the statement, and $61.5 \%$ of the participants disagree and strongly disagree respectively. While in the control group, $87 \%$ of the participants agree and strongly agree with the same statement, $13 \%$ of the participants neither agree nor disagree, and $0 \%$ disagree with the statement. Whereas $22.2 \%$ of the participants in the private experimental group agree with the same statement, $40.7 \%$ neither agree nor disagree with the statement, and $37 \%$ of the participants disagree with it..

While in the control group, $16.7 \%$ of the participants agree with the same statement,33.3\% neither agree nor disagree, and 50\% disagree with it. Such differences in the results between the control and experimental groups indicate that anxiety has dramatically decreased in the experimental group of the public school and almost all the participants have more responsibility, motivation and self confidence towards learning foreign language. Whereas the participants in the private school have lower anxiety level and still have irresponsibility which reflect their attitude towards the EFL learning. 
Table23. Q11. Anxiety pre test

\begin{tabular}{|c|c|c|c|c|c|c|c|}
\hline \multirow[t]{3}{*}{ School } & \multirow[t]{3}{*}{ Q11 } & \multicolumn{4}{|c|}{ Group } & \multicolumn{2}{|c|}{ Total } \\
\hline & & \multicolumn{2}{|c|}{ Experimental } & \multicolumn{2}{|c|}{ Control } & & \\
\hline & & $\mathrm{N}$ & $\%$ & $\mathrm{~N}$ & $\%$ & $\mathrm{~N}$ & $\%$ \\
\hline \multirow{6}{*}{ Public } & SA & 3 & $11.5 \%$ & 4 & $12.5 \%$ & 7 & $12.1 \%$ \\
\hline & A & 16 & $61.5 \%$ & 11 & $34.4 \%$ & 27 & $46.6 \%$ \\
\hline & NAND & 4 & $15.4 \%$ & 11 & $34.4 \%$ & 15 & $25.9 \%$ \\
\hline & DA & 2 & $7.7 \%$ & 5 & $15.6 \%$ & 7 & $12.1 \%$ \\
\hline & SD & 1 & $3.8 \%$ & 1 & $3.1 \%$ & 2 & $3.4 \%$ \\
\hline & Total & 26 & $100.0 \%$ & 32 & $100.0 \%$ & 58 & $100.0 \%$ \\
\hline \multirow[t]{6}{*}{ Private } & $\mathrm{SA}$ & 5 & $18.5 \%$ & 10 & $31.3 \%$ & 15 & $25.4 \%$ \\
\hline & A & 8 & $29.6 \%$ & 6 & $18.8 \%$ & 14 & $23.7 \%$ \\
\hline & NAND & 6 & $22.2 \%$ & 4 & $12.5 \%$ & 10 & $16.9 \%$ \\
\hline & DA & 5 & $18.5 \%$ & 6 & $18.8 \%$ & 11 & $18.6 \%$ \\
\hline & SD & 3 & $11.1 \%$ & 6 & $18.8 \%$ & 9 & $15.3 \%$ \\
\hline & Total & 27 & $100.0 \%$ & 32 & $100.0 \%$ & 59 & $100.0 \%$ \\
\hline \multirow[t]{6}{*}{ Total } & $\mathrm{SA}$ & 8 & $15.1 \%$ & 14 & $21.9 \%$ & 22 & $18.8 \%$ \\
\hline & A & 24 & $45.3 \%$ & 17 & $26.6 \%$ & 41 & $35.0 \%$ \\
\hline & NAND & 10 & $18.9 \%$ & 15 & $23.4 \%$ & 25 & $21.4 \%$ \\
\hline & DA & 7 & $13.2 \%$ & 11 & $17.2 \%$ & 18 & $15.4 \%$ \\
\hline & SD & 4 & $7.5 \%$ & 7 & $10.9 \%$ & 11 & $9.4 \%$ \\
\hline & Total & 53 & $100.0 \%$ & 64 & $100.0 \%$ & 117 & $100.0 \%$ \\
\hline
\end{tabular}

Table 23 revealed that $58.7 \%$ of the public school participants strongly agree and agree that they don't understand why some students get so upset over foreign language classes ,25.9\% neither agree nor disagree, and $15.5 \%$ disagree and strongly disagree respectively with the statement. Whereas $49.1 \%$ of the private school participants agree and strongly disagree with the same statement, $16.9 \%$ neither agree nor disagree, and $33.9 \%$ disagree and strongly disagree with the statement. Such results indicate that the majority of the participants in the public and private schools have moderate anxiety and that they find the EFL classes interesting. Whereas a good number of the participants are irresponsible and have no motivation towards the EFL class.

Table24. Q11. Anxiety post test results

\begin{tabular}{|c|c|c|c|c|c|c|c|}
\hline \multirow[t]{3}{*}{ School } & \multirow[t]{3}{*}{ Q11 } & \multicolumn{4}{|c|}{ Group } & \multicolumn{2}{|c|}{ Total } \\
\hline & & \multicolumn{2}{|c|}{ Experimental } & \multicolumn{2}{|c|}{ Control } & & \\
\hline & & $\mathrm{N}$ & $\%$ & $\mathrm{~N}$ & $\%$ & $\mathrm{~N}$ & $\%$ \\
\hline \multirow[t]{6}{*}{ Public } & SA & 5 & $19.2 \%$ & 0 & & 5 & $10.2 \%$ \\
\hline & A & 16 & $61.5 \%$ & 9 & $39.1 \%$ & 25 & $51.0 \%$ \\
\hline & NAND & 3 & $11.5 \%$ & 6 & $26.1 \%$ & 9 & $18.4 \%$ \\
\hline & DA & 2 & $7.7 \%$ & 8 & $34.8 \%$ & 10 & $20.4 \%$ \\
\hline & SD & & & & & & \\
\hline & Total & 26 & $100.0 \%$ & 23 & $100.0 \%$ & 49 & $100.0 \%$ \\
\hline \multirow[t]{6}{*}{ Private } & SA & 1 & $3.7 \%$ & 3 & $12.5 \%$ & 4 & $7.8 \%$ \\
\hline & A & 15 & $55.6 \%$ & 7 & $29.2 \%$ & 22 & $43.1 \%$ \\
\hline & NAND & 5 & $18.5 \%$ & 5 & $20.8 \%$ & 10 & $19.6 \%$ \\
\hline & DA & 5 & $18.5 \%$ & 6 & $25.0 \%$ & 11 & $21.6 \%$ \\
\hline & SD & 1 & $3.7 \%$ & 3 & $12.5 \%$ & 4 & $7.8 \%$ \\
\hline & Total & 27 & $100.0 \%$ & 24 & $100.0 \%$ & 51 & $100.0 \%$ \\
\hline \multirow[t]{6}{*}{ Total } & SA & 6 & $11.3 \%$ & 3 & $6.4 \%$ & 9 & $9.0 \%$ \\
\hline & A & 31 & $58.5 \%$ & 16 & $34.0 \%$ & 47 & $47.0 \%$ \\
\hline & NAND & 8 & $15.1 \%$ & 11 & $23.4 \%$ & 19 & $19.0 \%$ \\
\hline & DA & 7 & $13.2 \%$ & 14 & $29.8 \%$ & 21 & $21.0 \%$ \\
\hline & SD & 1 & $1.9 \%$ & 3 & $6.4 \%$ & 4 & $4.0 \%$ \\
\hline & Total & 53 & $100.0 \%$ & 47 & $100.0 \%$ & 100 & $100.0 \%$ \\
\hline
\end{tabular}

Table 24 of the anxiety post test revealed that $80.7 \%$ of the participants in the public experimental strongly agree and agree with that they don't understand why some people get so upset over foreign language classes, $11.5 \%$ of the participants neither agree nor disagree with the statement, and $7.7 \%$ of the participants disagree and strongly disagree respectively. While in the control group, $39.1 \%$ of the participants agree with the same statement, $26.1 \%$ of the participants neither agree nor disagree, and $34.8 \%$ disagree with the statement. Whereas $59.3 \%$ of the participants in the private experimental group agree and strongly agree with the same tested statement, $18.5 \%$ neither agree nor disagree with the statement, and $22.2 \%$ of the participants disagree with it. While in the control group, $41.7 \%$ of the 
participants agree with the same statement, $20.8 \%$ neither agree nor disagree, and $37.5 \%$ disagree with it. Such differences in the results between the control and experimental groups indicate that anxiety has dramatically decreased in the experimental groups and almost all the participants have more responsibility, motivation and self confidence towards the foreign language.

Table25. Q12. Anxiety pre test

\begin{tabular}{|c|c|c|c|c|c|c|c|}
\hline \multirow[t]{3}{*}{ School } & \multirow[t]{3}{*}{ Q12 } & \multicolumn{4}{|c|}{ Group } & \multicolumn{2}{|c|}{ Total } \\
\hline & & \multicolumn{2}{|c|}{ Experimental } & \multicolumn{2}{|c|}{ Control } & & \\
\hline & & $\mathrm{N}$ & $\%$ & $\mathrm{~N}$ & $\%$ & $\mathrm{~N}$ & $\%$ \\
\hline \multirow{6}{*}{ Public } & SA & 7 & $26.9 \%$ & 5 & $15.6 \%$ & 12 & $20.7 \%$ \\
\hline & A & 9 & $34.6 \%$ & 11 & $34.4 \%$ & 20 & $34.5 \%$ \\
\hline & NAND & 2 & $7.7 \%$ & 9 & $28.1 \%$ & 11 & $19.0 \%$ \\
\hline & DA & 5 & $19.2 \%$ & 6 & $18.8 \%$ & 11 & $19.0 \%$ \\
\hline & SD & 3 & $11.5 \%$ & 1 & $3.1 \%$ & 4 & $6.9 \%$ \\
\hline & Total & 26 & $100.0 \%$ & 32 & $100.0 \%$ & 58 & $100.0 \%$ \\
\hline \multirow[t]{6}{*}{ Private } & $\mathrm{SA}$ & 12 & $44.4 \%$ & 8 & $25.0 \%$ & 20 & $33.9 \%$ \\
\hline & $\mathrm{A}$ & 4 & $14.8 \%$ & 11 & $34.4 \%$ & 15 & $25.4 \%$ \\
\hline & NAND & 6 & $22.2 \%$ & 11 & $34.4 \%$ & 17 & $28.8 \%$ \\
\hline & DA & 2 & $7.4 \%$ & 0 & & 2 & $3.4 \%$ \\
\hline & SD & 3 & $11.1 \%$ & 2 & $6.3 \%$ & 5 & $8.5 \%$ \\
\hline & Total & 27 & $100.0 \%$ & 32 & $100.0 \%$ & 59 & $100.0 \%$ \\
\hline \multirow[t]{6}{*}{ Total } & $\mathrm{SA}$ & 19 & $35.8 \%$ & 13 & $20.3 \%$ & 32 & $27.4 \%$ \\
\hline & $\mathrm{A}$ & 13 & $24.5 \%$ & 22 & $34.4 \%$ & 35 & $29.9 \%$ \\
\hline & NAND & 8 & $15.1 \%$ & 20 & $31.3 \%$ & 28 & $23.9 \%$ \\
\hline & DA & 7 & $13.2 \%$ & 6 & $9.4 \%$ & 13 & $11.1 \%$ \\
\hline & SD & 6 & $11.3 \%$ & 3 & $4.7 \%$ & 9 & $7.7 \%$ \\
\hline & Total & 53 & $100.0 \%$ & 64 & $100.0 \%$ & 117 & $100.0 \%$ \\
\hline
\end{tabular}

Table 25 revealed that $55.2 \%$ of the public school participants strongly agree and agree that in foreign language classes, they get so nervous and forget things they know, 19\% neither agree nor disagree, and $25.9 \%$ disagree and strongly disagree respectively with the statement. Whereas $59.3 \%$ of the private school participants agree and strongly disagree with the same statement, 28.8\% neither agree nor disagree, and $11.9 \%$ disagree and strongly disagree with the statement. Such results indicate that the majority of the participants in the public and private schools have high anxiety that makes them unable to focus completely in the language learning sessions and forget things they know, which means that a good number of the participants especially in the private school are irresponsible and indifferent towards the EFL learning.

Table26. Q12. Anxiety post test results

\begin{tabular}{|c|c|c|c|c|c|c|c|}
\hline \multirow[t]{3}{*}{ School } & \multirow[t]{3}{*}{ Q12 } & \multicolumn{4}{|c|}{ Group } & \multicolumn{2}{|c|}{ Total } \\
\hline & & \multicolumn{2}{|c|}{ Experimental } & \multicolumn{2}{|c|}{ Control } & & \\
\hline & & $\mathrm{N}$ & $\%$ & $\mathrm{~N}$ & $\%$ & $\mathrm{~N}$ & $\%$ \\
\hline \multirow{6}{*}{ Public } & SA & 0 & $0 \%$ & 2 & $8.7 \%$ & 2 & $4.1 \%$ \\
\hline & A & 1 & $3.8 \%$ & 16 & $69.6 \%$ & 17 & $34.7 \%$ \\
\hline & NAND & 1 & $3.8 \%$ & 4 & $17.4 \%$ & 5 & $10.2 \%$ \\
\hline & DA & 9 & $34.6 \%$ & 1 & $4.3 \%$ & 10 & $20.4 \%$ \\
\hline & SD & 15 & $57.7 \%$ & 0 & & 15 & $30.6 \%$ \\
\hline & Total & 26 & $100.0 \%$ & 23 & $100.0 \%$ & 49 & $100.0 \%$ \\
\hline \multirow[t]{6}{*}{ Private } & SA & 0 & & 9 & $37.5 \%$ & 9 & $17.6 \%$ \\
\hline & A & 0 & & 7 & $29.2 \%$ & 7 & $13.7 \%$ \\
\hline & NAND & 1 & $3.7 \%$ & 5 & $20.8 \%$ & 6 & $11.8 \%$ \\
\hline & DA & 19 & $70.4 \%$ & 3 & $12.5 \%$ & 22 & $43.1 \%$ \\
\hline & SD & 7 & $25.9 \%$ & 0 & & 7 & $13.7 \%$ \\
\hline & Total & 27 & $100.0 \%$ & 24 & $100.0 \%$ & 51 & $100.0 \%$ \\
\hline \multirow[t]{6}{*}{ Total } & SA & 0 & & 11 & $23.4 \%$ & 11 & $11.0 \%$ \\
\hline & A & 1 & $1.9 \%$ & 23 & $48.9 \%$ & 24 & $24.0 \%$ \\
\hline & NAND & 2 & $3.8 \%$ & 9 & $19.1 \%$ & 11 & $11.0 \%$ \\
\hline & DA & 28 & $52.8 \%$ & 4 & $8.5 \%$ & 32 & $32.0 \%$ \\
\hline & SD & 22 & $41.5 \%$ & 0 & & 22 & $22.0 \%$ \\
\hline & Total & 53 & $100.0 \%$ & 47 & $100.0 \%$ & 100 & $100.0 \%$ \\
\hline
\end{tabular}

Table 26 of the anxiety posttest revealed that $3.8 \%$ of the participants in the public experimental group agree with that in foreign language class, they can get so nervous and forget things they know, $3.8 \%$ of the participants neither agree nor disagree with the statement, and $92.3 \%$ of the participants 
disagree and strongly disagree respectively. While in the control group, $78.3 \%$ of the participants agree and strongly agree with the same statement, $17.4 \%$ of the participants neither agree nor disagree, and $4.3 \%$ disagree with the tested statement. Whereas $0 \%$ of the participants in the private experimental group agree and strongly agree with the tested statement, $3.7 \%$ neither agree nor disagree, and $96.3 \%$ of the participants disagree with it, While in the control group, $66.7 \%$ of the participants agree with the tested statement, $20.8 \%$ neither agree nor disagree, and $12.5 \%$ disagree with it. Such differences in the results between the control and experimental groups indicate that anxiety has dramatically decreased in the experimental groups and almost all the participants have more responsibility and self confidence towards learning foreign language.

Table27. Q13. Anxiety pre test

\begin{tabular}{|c|c|c|c|c|c|c|c|}
\hline \multirow[t]{3}{*}{ School } & \multirow[t]{3}{*}{ Q13 } & \multicolumn{4}{|c|}{ Group } & \multicolumn{2}{|c|}{ Total } \\
\hline & & \multicolumn{2}{|c|}{ Experimental } & \multicolumn{2}{|c|}{ Control } & & \\
\hline & & $\mathrm{N}$ & $\%$ & $\mathrm{~N}$ & $\%$ & $\mathrm{~N}$ & $\%$ \\
\hline \multirow[t]{6}{*}{ Public } & SA & 2 & $7.7 \%$ & 1 & $3.1 \%$ & 3 & $5.2 \%$ \\
\hline & $\mathrm{A}$ & 10 & $38.5 \%$ & 9 & $28.1 \%$ & 19 & $32.8 \%$ \\
\hline & NAND & 2 & $7.7 \%$ & 4 & $12.5 \%$ & 6 & $10.3 \%$ \\
\hline & DA & 7 & $26.9 \%$ & 13 & $40.6 \%$ & 20 & $34.5 \%$ \\
\hline & SD & 5 & $19.2 \%$ & 5 & $15.6 \%$ & 10 & $17.2 \%$ \\
\hline & Total & 26 & $100.0 \%$ & 32 & $100.0 \%$ & 58 & $100.0 \%$ \\
\hline \multirow{6}{*}{ Private } & SA & 3 & $11.1 \%$ & 1 & $3.1 \%$ & 4 & $6.8 \%$ \\
\hline & A & 5 & $18.5 \%$ & 4 & $12.5 \%$ & 9 & $15.3 \%$ \\
\hline & NAND & 4 & $14.8 \%$ & 8 & $25.0 \%$ & 12 & $20.3 \%$ \\
\hline & DA & 8 & $29.6 \%$ & 3 & $9.4 \%$ & 11 & $18.6 \%$ \\
\hline & SD & 7 & $25.9 \%$ & 16 & $50.0 \%$ & 23 & $39.0 \%$ \\
\hline & Total & 27 & $100.0 \%$ & 32 & $100.0 \%$ & 59 & $100.0 \%$ \\
\hline \multirow[t]{6}{*}{ Total } & SA & 5 & $9.4 \%$ & 2 & $3.1 \%$ & 7 & $6.0 \%$ \\
\hline & A & 15 & $28.3 \%$ & 13 & $20.3 \%$ & 28 & $23.9 \%$ \\
\hline & NAND & 6 & $11.3 \%$ & 12 & $18.8 \%$ & 18 & $15.4 \%$ \\
\hline & DA & 15 & $28.3 \%$ & 16 & $25.0 \%$ & 31 & $26.5 \%$ \\
\hline & SD & 12 & $22.6 \%$ & 21 & $32.8 \%$ & 33 & $28.2 \%$ \\
\hline & Total & 53 & $100.0 \%$ & 64 & $100.0 \%$ & 117 & $100.0 \%$ \\
\hline
\end{tabular}

Table 27 revealed that $38 \%$ of the public school participants strongly agree and agree that it embarrasses them to volunteer answers in their foreign language class, $10.3 \%$ neither agree nor disagree, and $51.7 \%$ disagree and strongly disagree respectively with the statement. Whereas $22.1 \%$ of the private school participants agree and strongly disagree with the tested statement, $20.3 \%$ neither agree nor disagree, and $57.6 \%$ disagree and strongly disagree with the statement. Such results indicate that the majority of the participants in the public and private schools are willing to volunteer answers in their foreign language class whereas the rest of students have moderate anxiety, low self confidence and motivation that make them embarrassed to volunteer answers, noting that a bigger number of private school participants have irresponsibility and indifference towards the EFL class.

Table28. Q13. Anxiety post test results

\begin{tabular}{|c|c|c|c|c|c|c|c|}
\hline \multirow[t]{3}{*}{ School } & \multirow[t]{3}{*}{ Q13 } & \multicolumn{4}{|c|}{ Group } & \multicolumn{2}{|c|}{ Total } \\
\hline & & \multicolumn{2}{|c|}{ Experimental } & \multicolumn{2}{|c|}{ Control } & & \\
\hline & & $\mathrm{N}$ & $\%$ & $\mathrm{~N}$ & $\%$ & $\mathrm{~N}$ & $\%$ \\
\hline \multirow[t]{6}{*}{ Public } & SA & 0 & & 18 & $78.3 \%$ & 18 & $36.7 \%$ \\
\hline & $\mathrm{A}$ & 1 & $3.8 \%$ & 5 & $21.7 \%$ & 6 & $12.2 \%$ \\
\hline & NAND & & & & & & \\
\hline & DA & 6 & $23.1 \%$ & 0 & & 6 & $12.2 \%$ \\
\hline & SD & 19 & $73.1 \%$ & 0 & & 19 & $38.8 \%$ \\
\hline & Total & 26 & $100.0 \%$ & 23 & $100.0 \%$ & 49 & $100.0 \%$ \\
\hline \multirow[t]{6}{*}{ Private } & SA & 0 & & 1 & $4.2 \%$ & 1 & $2.0 \%$ \\
\hline & A & 0 & & 2 & $8.3 \%$ & 2 & $3.9 \%$ \\
\hline & NAND & 0 & & 7 & $29.2 \%$ & 7 & $13.7 \%$ \\
\hline & DA & 8 & $29.6 \%$ & 7 & $29.2 \%$ & 15 & $29.4 \%$ \\
\hline & SD & 19 & $70.4 \%$ & 7 & $29.2 \%$ & 26 & $51.0 \%$ \\
\hline & Total & 27 & $100.0 \%$ & 24 & $100.0 \%$ & 51 & $100.0 \%$ \\
\hline \multirow[t]{4}{*}{ Total } & SA & 0 & & 19 & $40.4 \%$ & 19 & $19.0 \%$ \\
\hline & A & 1 & $1.9 \%$ & 7 & $14.9 \%$ & 8 & $8.0 \%$ \\
\hline & NAND & 0 & & 7 & $14.9 \%$ & 7 & $7.0 \%$ \\
\hline & DA & 14 & $26.4 \%$ & 7 & $14.9 \%$ & 21 & $21.0 \%$ \\
\hline
\end{tabular}


Could Cll Approach be a Remedy for Tripoli Secondary Students Speaking Skills?

\begin{tabular}{|l|l|l|l|l|l|l|l|}
\hline & SD & 38 & $71.7 \%$ & 7 & $14.9 \%$ & 45 & $45.0 \%$ \\
\cline { 2 - 8 } & Total & 53 & $100.0 \%$ & 47 & $100.0 \%$ & 100 & $100.0 \%$ \\
\hline
\end{tabular}

Table 28 of the anxiety posttest showed that $3.8 \%$ of the participants in the public experimental group agree with that it embarrasses them to volunteer answers in their foreign language class, $0 \%$ of the participants neither agree nor disagree with the statement, and $96.2 \%$ of the participants disagree and strongly disagree respectively. While in the control group, $100 \%$ of the participants agree and strongly, $0 \%$ of the participants neither agree nor disagree, and $0 \%$ disagree with the same statement. Whereas $0 \%$ of the participants in the private experimental group agree and strongly agree with the tested statement, $0 \%$ neither agree nor disagree, and $100 \%$ of the participants disagree. While in the control group, $12.5 \%$ of the participants agree with the same statement, $29.2 \%$ neither agree nor disagree with the statement, and $58.4 \%$ disagree with it. Such differences in the results between the control and experimental groups indicate that anxiety has dramatically decreased in the experimental groups and almost all the participants have more responsibility and high self confidence towards their foreign language that makes them willing to volunteer their answers without embarrassment.

Table29. Q14. Anxiety pre test

\begin{tabular}{|c|c|c|c|c|c|c|c|}
\hline \multirow[t]{3}{*}{ School } & \multirow[t]{3}{*}{ Q14 } & \multicolumn{4}{|c|}{ Group } & \multicolumn{2}{|c|}{ Total } \\
\hline & & \multicolumn{2}{|c|}{ Experimental } & \multicolumn{2}{|c|}{ Control } & & \\
\hline & & $\mathrm{N}$ & $\%$ & $\mathrm{~N}$ & $\%$ & $\mathrm{~N}$ & $\%$ \\
\hline \multirow[t]{6}{*}{ Public } & SA & 4 & $15.4 \%$ & 5 & $15.6 \%$ & 9 & $15.5 \%$ \\
\hline & A & 14 & $53.8 \%$ & 7 & $21.9 \%$ & 21 & $36.2 \%$ \\
\hline & NAND & 6 & $23.1 \%$ & 7 & $21.9 \%$ & 13 & $22.4 \%$ \\
\hline & DA & 2 & $7.7 \%$ & 12 & $37.5 \%$ & 14 & $24.1 \%$ \\
\hline & SD & 0 & & 1 & $3.1 \%$ & 1 & $1.7 \%$ \\
\hline & Total & 26 & $100.0 \%$ & 32 & $100.0 \%$ & 58 & $100.0 \%$ \\
\hline \multirow[t]{6}{*}{ Private } & SA & 9 & $34.6 \%$ & 15 & $48.4 \%$ & 24 & $42.1 \%$ \\
\hline & A & 3 & $11.5 \%$ & 4 & $12.9 \%$ & 7 & $12.3 \%$ \\
\hline & NAND & 4 & $15.4 \%$ & 5 & $16.1 \%$ & 9 & $15.8 \%$ \\
\hline & DA & 5 & $19.2 \%$ & 5 & $16.1 \%$ & 10 & $17.5 \%$ \\
\hline & $\mathrm{SD}$ & 5 & $19.2 \%$ & 2 & $6.5 \%$ & 7 & $12.3 \%$ \\
\hline & Total & 26 & $100.0 \%$ & 31 & $100.0 \%$ & 57 & $100.0 \%$ \\
\hline \multirow[t]{6}{*}{ Total } & SA & 13 & $25.0 \%$ & 20 & $31.7 \%$ & 33 & $28.7 \%$ \\
\hline & $\mathrm{A}$ & 17 & $32.7 \%$ & 11 & $17.5 \%$ & 28 & $24.3 \%$ \\
\hline & NAND & 10 & $19.2 \%$ & 12 & $19.0 \%$ & 22 & $19.1 \%$ \\
\hline & DA & 7 & $13.5 \%$ & 17 & $27.0 \%$ & 24 & $20.9 \%$ \\
\hline & $\mathrm{SD}$ & 5 & $9.6 \%$ & 3 & $4.8 \%$ & 8 & $7.0 \%$ \\
\hline & Total & 52 & $100.0 \%$ & 63 & $100.0 \%$ & 115 & $100.0 \%$ \\
\hline
\end{tabular}

Table 29 revealed that $51.7 \%$ of the public school participants strongly agree and agree that they would not be nervous speaking the foreign language with native speakers, $22.4 \%$ neither agree nor disagree, and $25.8 \%$ disagree and strongly disagree respectively with the statement. Whereas $54.4 \%$ of the private school participants agree and strongly disagree with the tested statement, $15.8 \%$ neither agree nor disagree, and $29.8 \%$ disagree and strongly disagree with the statement. Such results indicate that the majority of participants in the public and private schools have high anxiety and low self confidence that makes them nervous when speaking the foreign language with native speakers.

Table30. Q14. Anxiety post test results

\begin{tabular}{|c|c|c|c|c|c|c|c|}
\hline \multirow[t]{3}{*}{ School } & \multirow[t]{3}{*}{ Q14.I } & \multicolumn{4}{|c|}{ Group } & \multicolumn{2}{|c|}{ Total } \\
\hline & & \multicolumn{2}{|c|}{ Experimental } & \multicolumn{2}{|c|}{ Control } & & \\
\hline & & $\mathrm{N}$ & $\%$ & $\mathrm{~N}$ & $\%$ & $\mathrm{~N}$ & $\%$ \\
\hline \multirow{6}{*}{ Public } & SA & 2 & $7.7 \%$ & 0 & & 2 & $4.1 \%$ \\
\hline & $\mathrm{A}$ & 14 & $53.8 \%$ & 0 & & 14 & $28.6 \%$ \\
\hline & NAND & 4 & $15.4 \%$ & 1 & $4.3 \%$ & 5 & $10.2 \%$ \\
\hline & DA & 5 & $19.2 \%$ & 9 & $39.1 \%$ & 14 & $28.6 \%$ \\
\hline & SD & 1 & $3.8 \%$ & 13 & $56.5 \%$ & 14 & $28.6 \%$ \\
\hline & Total & 26 & $100.0 \%$ & 23 & $100.0 \%$ & 49 & $100.0 \%$ \\
\hline \multirow[t]{6}{*}{ Private } & SA & 4 & $14.8 \%$ & 10 & $41.7 \%$ & 14 & $27.5 \%$ \\
\hline & $\mathrm{A}$ & 15 & $55.6 \%$ & 3 & $12.5 \%$ & 18 & $35.3 \%$ \\
\hline & NAND & 5 & $18.5 \%$ & 5 & $20.8 \%$ & 10 & $19.6 \%$ \\
\hline & DA & 3 & $11.1 \%$ & 4 & $16.7 \%$ & 7 & $13.7 \%$ \\
\hline & SD & 0 & & 2 & $8.3 \%$ & 2 & $3.9 \%$ \\
\hline & Total & 27 & $100.0 \%$ & 24 & $100.0 \%$ & 51 & $100.0 \%$ \\
\hline
\end{tabular}




\begin{tabular}{|l|l|l|l|l|l|l|l|}
\hline \multirow{5}{*}{ Total } & SA & 6 & $11.3 \%$ & 10 & $21.3 \%$ & 16 & $16.0 \%$ \\
\cline { 2 - 8 } & A & 29 & $54.7 \%$ & 3 & $6.4 \%$ & 32 & $32.0 \%$ \\
\cline { 2 - 8 } & NAND & 9 & $17.0 \%$ & 6 & $12.8 \%$ & 15 & $15.0 \%$ \\
\cline { 2 - 8 } & DA & 8 & $15.1 \%$ & 13 & $27.7 \%$ & 21 & $21.0 \%$ \\
\cline { 2 - 8 } & SD & 1 & $1.9 \%$ & 15 & $31.9 \%$ & 16 & $16.0 \%$ \\
\cline { 2 - 8 } & Total & 53 & $100.0 \%$ & 47 & $100.0 \%$ & 100 & $100.0 \%$ \\
\hline
\end{tabular}

Table 30 of the anxiety posttest showed that $61.5 \%$ of the participants in the public experimental group strongly agree and agree with that they would not be nervous speaking the foreign language with native speakers, $15.4 \%$ of the participants neither agree nor disagree, and $23 \%$ of the participants disagree and strongly disagree with the statement respectively. While in the control group, $0 \%$ of the participants agree and strongly agree with that they would not be nervous speaking the foreign language with native speakers, $4.3 \%$ of the participants neither agree nor disagree, and $95.7 \%$ disagree with the statement. Whereas $70.4 \%$ of the participants in the private experimental group agree and strongly agree with that they would not be nervous speaking the foreign language with native speakers, $18.5 \%$ neither agree nor disagree, and $11.1 \%$ of the participants disagree with the same statement. While in the control group, $54.2 \%$ of the participants agree with that they would not be nervous speaking the foreign language with native speakers, $20.8 \%$ neither agree nor disagree, and $25 \%$ disagree with it. Such differences in the results between the control and experimental groups indicate that anxiety has dramatically decreased in the experimental groups after implementing the CLL approach and almost all the participants have high self confidence towards speaking the foreign language with native speakers.

Table31. Q15. Anxiety pre test

\begin{tabular}{|c|c|c|c|c|c|c|c|}
\hline \multirow[t]{3}{*}{ School } & \multirow[t]{3}{*}{ Q15.I } & \multicolumn{4}{|c|}{ Group } & \multicolumn{2}{|c|}{ Total } \\
\hline & & \multicolumn{2}{|c|}{ Experimental } & \multicolumn{2}{|c|}{ Control } & & \\
\hline & & $\mathrm{N}$ & $\%$ & $\mathrm{~N}$ & $\%$ & $\mathrm{~N}$ & $\%$ \\
\hline \multirow[t]{6}{*}{ Public } & SA & 6 & $23.1 \%$ & 1 & $3.1 \%$ & 7 & $12.1 \%$ \\
\hline & A & 7 & $26.9 \%$ & 7 & $21.9 \%$ & 14 & $24.1 \%$ \\
\hline & NAND & 9 & $34.6 \%$ & 18 & $56.3 \%$ & 27 & $46.6 \%$ \\
\hline & DA & 4 & $15.4 \%$ & 6 & $18.8 \%$ & 10 & $17.2 \%$ \\
\hline & SD & 0 & $0.0 \%$ & 0 & $0.0 \%$ & 0 & $0.0 \%$ \\
\hline & Total & 26 & $100.0 \%$ & 32 & $100.0 \%$ & 58 & $100.0 \%$ \\
\hline \multirow[t]{6}{*}{ Private } & $\mathrm{SA}$ & 5 & $19.2 \%$ & 15 & $46.9 \%$ & 20 & $34.5 \%$ \\
\hline & A & 4 & $15.4 \%$ & 8 & $25.0 \%$ & 12 & $20.7 \%$ \\
\hline & NAND & 3 & $11.5 \%$ & 2 & $6.3 \%$ & 5 & $8.6 \%$ \\
\hline & DA & 7 & $26.9 \%$ & 4 & $12.5 \%$ & 11 & $19.0 \%$ \\
\hline & SD & 7 & $26.9 \%$ & 3 & $9.4 \%$ & 10 & $17.2 \%$ \\
\hline & Total & 26 & $100.0 \%$ & 32 & $100.0 \%$ & 58 & $100.0 \%$ \\
\hline \multirow[t]{6}{*}{ Total } & $\mathrm{SA}$ & 11 & $21.2 \%$ & 16 & $25.0 \%$ & 27 & $23.3 \%$ \\
\hline & A & 11 & $21.2 \%$ & 15 & $23.4 \%$ & 26 & $22.4 \%$ \\
\hline & NAND & 12 & $23.1 \%$ & 20 & $31.3 \%$ & 32 & $27.6 \%$ \\
\hline & DA & 11 & $21.2 \%$ & 10 & $15.6 \%$ & 21 & $18.1 \%$ \\
\hline & SD & 7 & $13.5 \%$ & 3 & $4.7 \%$ & 10 & $8.6 \%$ \\
\hline & Total & 52 & $100.0 \%$ & 64 & $100.0 \%$ & 116 & $100.0 \%$ \\
\hline
\end{tabular}

Table 31 showed that $36.2 \%$ of the public school participants strongly agree and agree that they get upset when they don't understand what the teacher is correcting, $46.6 \%$ neither agree nor disagree, and $17.2 \%$ disagree with the statement. Whereas $55.2 \%$ of the private school participants agree and strongly disagree, $8.6 \%$ neither agree nor disagree, and $36.2 \%$ disagree and strongly disagree respectively with the same statement.

Such results indicate that the majority of participants in the public school are irresponsible and indifferent towards the EFL and have no motivation towards learning a new language with moderate anxiety. Whereas the majority of the participants in the private school have moderate anxiety but they are responsible and motivated towards the foreign language learning.

Table32. Q15. Anxiety post test results

\begin{tabular}{|c|c|c|c|c|c|c|c|}
\hline \multirow[t]{3}{*}{ School } & \multirow[t]{3}{*}{ Q15.I } & \multicolumn{4}{|c|}{ Group } & \multicolumn{2}{|c|}{ Total } \\
\hline & & \multicolumn{2}{|c|}{ Experimental } & \multicolumn{2}{|c|}{ Control } & & \\
\hline & & $\mathrm{N}$ & $\%$ & $\mathrm{~N}$ & $\%$ & $\mathrm{~N}$ & $\%$ \\
\hline \multirow[t]{2}{*}{ Public } & SA & 2 & $7.7 \%$ & 14 & $60.9 \%$ & 16 & $32.7 \%$ \\
\hline & A & 10 & $38.5 \%$ & 9 & $39.1 \%$ & 19 & $38.8 \%$ \\
\hline
\end{tabular}


Could Cll Approach be a Remedy for Tripoli Secondary Students Speaking Skills?

\begin{tabular}{|c|c|c|c|c|c|c|c|}
\hline & NAND & 8 & $30.8 \%$ & 0 & & 8 & $16.3 \%$ \\
\hline & DA & 5 & $19.2 \%$ & 0 & & 5 & $10.2 \%$ \\
\hline & SD & 1 & $3.8 \%$ & 0 & & 1 & $2.0 \%$ \\
\hline & Total & 26 & $100.0 \%$ & 23 & $100.0 \%$ & 49 & $100.0 \%$ \\
\hline \multirow[t]{6}{*}{ Private } & SA & 1 & $3.7 \%$ & 6 & $25.0 \%$ & 7 & $13.7 \%$ \\
\hline & A & 15 & $55.6 \%$ & 4 & $16.7 \%$ & 19 & $37.3 \%$ \\
\hline & NAND & 3 & $11.1 \%$ & 4 & $16.7 \%$ & 7 & $13.7 \%$ \\
\hline & DA & 8 & $29.6 \%$ & 5 & $20.8 \%$ & 13 & $25.5 \%$ \\
\hline & SD & 0 & & 5 & $20.8 \%$ & 5 & $9.8 \%$ \\
\hline & Total & 27 & $100.0 \%$ & 24 & $100.0 \%$ & 51 & $100.0 \%$ \\
\hline \multirow[t]{6}{*}{ Total } & SA & 3 & $5.7 \%$ & 20 & $42.6 \%$ & 23 & $23.0 \%$ \\
\hline & $\mathrm{A}$ & 25 & $47.2 \%$ & 13 & $27.7 \%$ & 38 & $38.0 \%$ \\
\hline & NAND & 11 & $20.8 \%$ & 4 & $8.5 \%$ & 15 & $15.0 \%$ \\
\hline & DA & 13 & $24.5 \%$ & 5 & $10.6 \%$ & 18 & $18.0 \%$ \\
\hline & SD & 1 & $1.9 \%$ & 5 & $10.6 \%$ & 6 & $6.0 \%$ \\
\hline & Total & 53 & $100.0 \%$ & 47 & $100.0 \%$ & 100 & $100.0 \%$ \\
\hline
\end{tabular}

Table 32 of the anxiety posttest revealed that $46.2 \%$ of the participants in the public experimental group strongly agree and agree with the tested statement, $30.8 \%$ of the participants neither agree nor disagree with the statement, and $23 \%$ of the participants disagree and strongly disagree respectively. While in the control group, $100 \%$ of the participants agree and strongly agree $0 \%$ of the participants neither agree nor disagree, and 0\% disagree with the same statement. Whereas $59.3 \%$ of the participants in the experimental group of the private school agree and strongly agree with the tested statement, $11.1 \%$ neither agree nor disagree with the statement, and $29.6 \%$ of the participants disagree with it, while in the control group, $41.7 \%$ of the participants agree and strongly agree, $16.7 \%$ neither agree nor disagree, and $41.6 \%$ disagree with the same statement. Such differences in the results between the control and experimental groups indicate that anxiety has decreased in the experimental groups and almost all the participants have more responsibility and self confidence towards learning foreign language especially in the private school.

Table33. Q16. Anxiety pre test

\begin{tabular}{|c|c|c|c|c|c|c|c|}
\hline \multirow[t]{3}{*}{ School } & \multirow[t]{3}{*}{ Q16 } & \multicolumn{4}{|c|}{ Group } & \multicolumn{2}{|c|}{ Total } \\
\hline & & \multicolumn{2}{|c|}{ Experimental } & \multicolumn{2}{|c|}{ Control } & & \\
\hline & & $\mathrm{N}$ & $\%$ & $\mathrm{~N}$ & $\%$ & $\mathrm{~N}$ & $\%$ \\
\hline \multirow{6}{*}{ Public } & SA & 2 & $7.7 \%$ & 2 & $6.3 \%$ & 4 & $6.9 \%$ \\
\hline & $\mathrm{A}$ & 7 & $26.9 \%$ & 7 & $21.9 \%$ & 14 & $24.1 \%$ \\
\hline & NAND & 2 & $7.7 \%$ & 11 & $34.4 \%$ & 13 & $22.4 \%$ \\
\hline & DA & 11 & $42.3 \%$ & 9 & $28.1 \%$ & 20 & $34.5 \%$ \\
\hline & SD & 4 & $15.4 \%$ & 3 & $9.4 \%$ & 7 & $12.1 \%$ \\
\hline & Total & 26 & $100.0 \%$ & 32 & $100.0 \%$ & 58 & $100.0 \%$ \\
\hline \multirow[t]{6}{*}{ Private } & $\mathrm{SA}$ & 3 & $12.0 \%$ & 2 & $6.3 \%$ & 5 & $8.8 \%$ \\
\hline & $\mathrm{A}$ & 2 & $8.0 \%$ & 9 & $28.1 \%$ & 11 & $19.3 \%$ \\
\hline & NAND & 5 & $20.0 \%$ & 5 & $15.6 \%$ & 10 & $17.5 \%$ \\
\hline & DA & 10 & $40.0 \%$ & 9 & $28.1 \%$ & 19 & $33.3 \%$ \\
\hline & SD & 5 & $20.0 \%$ & 7 & $21.9 \%$ & 12 & $21.1 \%$ \\
\hline & Total & 25 & $100.0 \%$ & 32 & $100.0 \%$ & 57 & $100.0 \%$ \\
\hline \multirow[t]{6}{*}{ Total } & $\mathrm{SA}$ & 5 & $9.8 \%$ & 4 & $6.3 \%$ & 9 & $7.8 \%$ \\
\hline & $\mathrm{A}$ & 9 & $17.6 \%$ & 16 & $25.0 \%$ & 25 & $21.7 \%$ \\
\hline & NAND & 7 & $13.7 \%$ & 16 & $25.0 \%$ & 23 & $20.0 \%$ \\
\hline & DA & 21 & $41.2 \%$ & 18 & $28.1 \%$ & 39 & $33.9 \%$ \\
\hline & SD & 9 & $17.6 \%$ & 10 & $15.6 \%$ & 19 & $16.5 \%$ \\
\hline & Total & 51 & $100.0 \%$ & 64 & $100.0 \%$ & 115 & $100.0 \%$ \\
\hline
\end{tabular}

Table 33 revealed that $31 \%$ of the public school participants strongly agree and agree that even if they are well prepared for foreign language class, they feel anxious about it, 22.4\% neither agree nor disagree, and $46.6 \%$ disagree and strongly disagree respectively with the statement. Whereas $28.1 \%$ of the private school participants agree and strongly disagree with the tested statement, $17.5 \%$ neither agree nor disagree, and $54.4 \%$ disagree and strongly disagree with the statement. Such results indicate that the majority of participants in the public and private schools have low anxiety level even when they are well prepared for the foreign language class and the rest of the participants have moderate anxiety, low self confidence and irresponsibility towards the EFL class. 
Table34. Q16. Anxiety post test results

\begin{tabular}{|c|c|c|c|c|c|c|c|}
\hline \multirow[t]{3}{*}{ School } & \multirow[t]{3}{*}{ Q16 } & \multicolumn{4}{|c|}{ Group } & \multicolumn{2}{|c|}{ Total } \\
\hline & & \multicolumn{2}{|c|}{ Experimental } & \multicolumn{2}{|c|}{ Control } & & \\
\hline & & $\mathrm{N}$ & $\%$ & $\mathrm{~N}$ & $\%$ & $\mathrm{~N}$ & $\%$ \\
\hline \multirow{6}{*}{ Public } & SA & 0 & & 11 & $47.8 \%$ & 11 & $22.4 \%$ \\
\hline & A & 1 & $3.8 \%$ & 11 & $47.8 \%$ & 12 & $24.5 \%$ \\
\hline & NAND & 2 & $7.7 \%$ & 1 & $4.3 \%$ & 3 & $6.1 \%$ \\
\hline & DA & 14 & $53.8 \%$ & 0 & & 14 & $28.6 \%$ \\
\hline & SD & 9 & $34.6 \%$ & 0 & & 9 & $18.4 \%$ \\
\hline & Total & 26 & $100.0 \%$ & 23 & $100.0 \%$ & 49 & $100.0 \%$ \\
\hline \multirow{6}{*}{ Private } & SA & 0 & & 5 & $20.8 \%$ & 5 & $9.8 \%$ \\
\hline & $\mathrm{A}$ & 3 & $11.1 \%$ & 5 & $20.8 \%$ & 8 & $15.7 \%$ \\
\hline & NAND & 22 & $81.5 \%$ & 10 & $41.7 \%$ & 32 & $62.7 \%$ \\
\hline & DA & 2 & $7.4 \%$ & 4 & $16.7 \%$ & 6 & $11.8 \%$ \\
\hline & SD & 0 & & 11 & $23.4 \%$ & 11 & $11.0 \%$ \\
\hline & Total & 27 & $100.0 \%$ & 24 & $100.0 \%$ & 51 & $100.0 \%$ \\
\hline \multirow{6}{*}{ Total } & $\mathrm{SA}$ & 1 & $1.9 \%$ & 16 & $34.0 \%$ & 17 & $17.0 \%$ \\
\hline & $\mathrm{A}$ & 5 & $9.4 \%$ & 6 & $12.8 \%$ & 11 & $11.0 \%$ \\
\hline & NAND & 36 & $67.9 \%$ & 10 & $21.3 \%$ & 46 & $46.0 \%$ \\
\hline & DA & 11 & $20.8 \%$ & 4 & $8.5 \%$ & 15 & $15.0 \%$ \\
\hline & SD & 9 & 34.6 & 11 & 23.4 & 20 & 29.4 \\
\hline & Total & 53 & $100.0 \%$ & 47 & $100.0 \%$ & 100 & $100.0 \%$ \\
\hline
\end{tabular}

Table 34 of the anxiety posttest showed that $3.8 \%$ of the participants in the public experimental group agree with that even if they are well prepared for foreign language class, they feel anxious about it, $7.7 \%$ of the participants neither agree nor disagree with the statement, and $88.4 \%$ of the participants disagree and strongly disagree respectively. While in the control group, $95.6 \%$ of the participants agree and strongly agree with the tested statement, $4.3 \%$ of the participants neither agree nor disagree, and $0 \%$ disagree with it.

Whereas $11.1 \%$ of the participants in the private experimental group agree and strongly agree with the tested statement, $81.5 \%$ neither agree nor disagree with the statement, and $7.4 \%$ of the participants disagree with it. While in the control group, $41.6 \%$ of the participants agree with the tested statement, $41.7 \%$ neither agree nor disagree, and $40.1 \%$ disagree with it.

Such differences in the results between the control and experimental groups indicate that anxiety has dramatically decreased in the experimental groups especially in the public school and all participants have more self confidence after implementing CLL approach.

Table35. Q17. Anxiety pre test

\begin{tabular}{|c|c|c|c|c|c|c|c|}
\hline \multirow[t]{3}{*}{ School } & \multirow[t]{3}{*}{ Q17.I } & \multicolumn{4}{|c|}{ Group } & \multicolumn{2}{|c|}{ Total } \\
\hline & & \multicolumn{2}{|c|}{ Experimental } & \multicolumn{2}{|c|}{ Control } & & \\
\hline & & $\mathrm{N}$ & $\%$ & $\mathrm{~N}$ & $\%$ & $\mathrm{~N}$ & $\%$ \\
\hline \multirow{6}{*}{ Public } & $\mathrm{SA}$ & 0 & $0.0 \%$ & 2 & $6.3 \%$ & 2 & $3.4 \%$ \\
\hline & A & 7 & $26.9 \%$ & 6 & $18.8 \%$ & 13 & $22.4 \%$ \\
\hline & NAND & 4 & $15.4 \%$ & 7 & $21.9 \%$ & 11 & $19.0 \%$ \\
\hline & DA & 11 & $42.3 \%$ & 14 & $43.8 \%$ & 25 & $43.1 \%$ \\
\hline & SD & 4 & $15.4 \%$ & 3 & $9.4 \%$ & 7 & $12.1 \%$ \\
\hline & Total & 26 & $100.0 \%$ & 32 & $100.0 \%$ & 58 & $100.0 \%$ \\
\hline \multirow[t]{6}{*}{ Private } & $\mathrm{SA}$ & 5 & $19.2 \%$ & 1 & $3.1 \%$ & 6 & $10.3 \%$ \\
\hline & A & 7 & $26.9 \%$ & 4 & $12.5 \%$ & 11 & $19.0 \%$ \\
\hline & NAND & 4 & $15.4 \%$ & 8 & $25.0 \%$ & 12 & $20.7 \%$ \\
\hline & DA & 7 & $26.9 \%$ & 11 & $34.4 \%$ & 18 & $31.0 \%$ \\
\hline & SD & 3 & $11.5 \%$ & 8 & $25.0 \%$ & 11 & $19.0 \%$ \\
\hline & Total & 26 & $100.0 \%$ & 32 & $100.0 \%$ & 58 & $100.0 \%$ \\
\hline \multirow{6}{*}{ Total } & $\mathrm{SA}$ & 5 & $9.6 \%$ & 3 & $4.7 \%$ & 8 & $6.9 \%$ \\
\hline & $\mathrm{A}$ & 14 & $26.9 \%$ & 10 & $15.6 \%$ & 24 & $20.7 \%$ \\
\hline & NAND & 8 & $15.4 \%$ & 15 & $23.4 \%$ & 23 & $19.8 \%$ \\
\hline & DA & 18 & $34.6 \%$ & 25 & $39.1 \%$ & 43 & $37.1 \%$ \\
\hline & SD & 7 & $13.5 \%$ & 11 & $17.2 \%$ & 18 & $15.5 \%$ \\
\hline & Total & 52 & $100.0 \%$ & 64 & $100.0 \%$ & 116 & $100.0 \%$ \\
\hline
\end{tabular}

Table 35 revealed that $25.8 \%$ of the public school participants strongly agree and agree that they often feel like not going to their foreign language class, $19 \%$ neither agree nor disagree, and $55.2 \%$ disagree and strongly disagree respectively with the statement. 
Whereas $29.3 \%$ of the private school participants agree and strongly disagree with the tested statement, $20.7 \%$ neither agree nor disagree, and 50\% disagree and strongly disagree with the statement. Such results indicate that the majority of the participants in the public and private schools have moderate anxiety whereas the rest of the participants have high anxiety, irresponsibility and no motivation towards the foreign language class.

Table36. Q17. Anxiety post test results

\begin{tabular}{|c|c|c|c|c|c|c|c|}
\hline \multirow[t]{3}{*}{ School } & \multirow[t]{3}{*}{ Q17.I } & \multicolumn{4}{|c|}{ Group } & \multicolumn{2}{|c|}{ Total } \\
\hline & & \multicolumn{2}{|c|}{ Experimental } & \multicolumn{2}{|c|}{ Control } & & \\
\hline & & $\mathrm{N}$ & $\%$ & $\mathrm{~N}$ & $\%$ & $\mathrm{~N}$ & $\%$ \\
\hline \multirow[t]{6}{*}{ Public } & SA & & & & & & \\
\hline & A & 1 & $3.8 \%$ & 12 & $52.2 \%$ & 13 & $26.5 \%$ \\
\hline & NAND & 7 & $26.9 \%$ & 9 & $39.1 \%$ & 16 & $32.7 \%$ \\
\hline & DA & 12 & $46.2 \%$ & 2 & $8.7 \%$ & 14 & $28.6 \%$ \\
\hline & SD & 6 & $23.1 \%$ & 0 & & 6 & $12.2 \%$ \\
\hline & Total & 26 & $100.0 \%$ & 23 & $100.0 \%$ & 49 & $100.0 \%$ \\
\hline \multirow[t]{6}{*}{ Private } & $\mathrm{SA}$ & 0 & & 3 & $12.5 \%$ & 3 & $5.9 \%$ \\
\hline & A & 1 & $3.7 \%$ & 7 & $29.2 \%$ & 8 & $15.7 \%$ \\
\hline & NAND & 3 & $11.1 \%$ & 6 & $25.0 \%$ & 9 & $17.6 \%$ \\
\hline & DA & 14 & $51.9 \%$ & 5 & $20.8 \%$ & 19 & $37.3 \%$ \\
\hline & SD & 9 & $33.3 \%$ & 3 & $12.5 \%$ & 12 & $23.5 \%$ \\
\hline & Total & 27 & $100.0 \%$ & 24 & $100.0 \%$ & 51 & $100.0 \%$ \\
\hline \multirow[t]{6}{*}{ Total } & $\mathrm{SA}$ & 0 & & 3 & $6.4 \%$ & 3 & $3.0 \%$ \\
\hline & A & 2 & $3.8 \%$ & 19 & $40.4 \%$ & 21 & $21.0 \%$ \\
\hline & NAND & 10 & $18.9 \%$ & 15 & $31.9 \%$ & 25 & $25.0 \%$ \\
\hline & DA & 26 & $49.1 \%$ & 7 & $14.9 \%$ & 33 & $33.0 \%$ \\
\hline & SD & 15 & $28.3 \%$ & 3 & $6.4 \%$ & 18 & $18.0 \%$ \\
\hline & Total & 53 & $100.0 \%$ & 47 & $100.0 \%$ & 100 & $100.0 \%$ \\
\hline
\end{tabular}

Table 36 of the anxiety posttest revealed that $3.8 \%$ of the participants in the public experimental group agree with that they often feel like not going to their foreign language class, $26.9 \%$ of the participants neither agree nor disagree with the statement, and $69.3 \%$ of the participants disagree and strongly disagree respectively. While in the control group, $52.2 \%$ of the participants agree with the tested statement, $39.1 \%$ of the participants neither agree nor disagree, and $8.7 \%$ disagree with the statement. Whereas $3.7 \%$ of the participants in the experimental group of the private school agree with the same tested statement, $11.1 \%$ neither agree nor disagree, and $85.2 \%$ of the participants disagree with it. While in the control group, $41.7 \%$ of the participants agree with, $25 \%$ neither agree nor disagree, and $33.3 \%$ disagree with the same statement. Such differences in the results between the control and experimental groups indicate that anxiety has dramatically decreased in the experimental groups and almost all the participants have more responsibility, motivation and self confidence towards learning foreign language.

Table37. Q18. Anxiety pre test

\begin{tabular}{|c|c|c|c|c|c|c|c|}
\hline \multirow[t]{3}{*}{ School } & \multirow[t]{3}{*}{ Q18.I } & \multicolumn{4}{|c|}{ Group } & \multicolumn{2}{|c|}{ Total } \\
\hline & & \multicolumn{2}{|c|}{ Experimental } & \multicolumn{2}{|c|}{ Control } & & \\
\hline & & $\mathrm{N}$ & $\%$ & $\mathrm{~N}$ & $\%$ & $\mathrm{~N}$ & $\%$ \\
\hline \multirow[t]{6}{*}{ Public } & SA & 6 & $23.1 \%$ & 4 & $12.5 \%$ & 10 & $17.2 \%$ \\
\hline & $\mathrm{A}$ & 9 & $34.6 \%$ & 8 & $25.0 \%$ & 17 & $29.3 \%$ \\
\hline & NAND & 8 & $30.8 \%$ & 15 & $46.9 \%$ & 23 & $39.7 \%$ \\
\hline & $\mathrm{DA}$ & 3 & $11.5 \%$ & 4 & $12.5 \%$ & 7 & $12.1 \%$ \\
\hline & SD & 0 & & 1 & $3.1 \%$ & 1 & $1.7 \%$ \\
\hline & Total & 26 & $100.0 \%$ & 32 & $100.0 \%$ & 58 & $100.0 \%$ \\
\hline \multirow[t]{6}{*}{ Private } & $\mathrm{SA}$ & 4 & $15.4 \%$ & 17 & $53.1 \%$ & 21 & $36.2 \%$ \\
\hline & A & 5 & $19.2 \%$ & 6 & $18.8 \%$ & 11 & $19.0 \%$ \\
\hline & NAND & 4 & $15.4 \%$ & 6 & $18.8 \%$ & 10 & $17.2 \%$ \\
\hline & DA & 5 & $19.2 \%$ & 0 & & 5 & $8.6 \%$ \\
\hline & SD & 8 & $30.8 \%$ & 3 & $9.4 \%$ & 11 & $19.0 \%$ \\
\hline & Total & 26 & $100.0 \%$ & 32 & $100.0 \%$ & 58 & $100.0 \%$ \\
\hline \multirow[t]{6}{*}{ Total } & $\mathrm{SA}$ & 10 & $19.2 \%$ & 21 & $32.8 \%$ & 31 & $26.7 \%$ \\
\hline & A & 14 & $26.9 \%$ & 14 & $21.9 \%$ & 28 & $24.1 \%$ \\
\hline & NAND & 12 & $23.1 \%$ & 21 & $32.8 \%$ & 33 & $28.4 \%$ \\
\hline & DA & 8 & $15.4 \%$ & 4 & $6.3 \%$ & 12 & $10.3 \%$ \\
\hline & SD & 8 & $15.4 \%$ & 4 & $6.3 \%$ & 12 & $10.3 \%$ \\
\hline & Total & 52 & $100.0 \%$ & 64 & $100.0 \%$ & 116 & $100.0 \%$ \\
\hline
\end{tabular}


Table 37, revealed that $46.5 \%$ of the public school participants strongly agree and agree that they feel confident when they speak in foreign language class, $39.7 \%$ neither agree nor disagree, and $13.8 \%$ disagree and strongly disagree respectively with the statement, whereas $55.2 \%$ of the private school participants agree and strongly disagree, $17.2 \%$ neither agree nor disagree, and $27.6 \%$ disagree and strongly disagree with the same statement.

Such results indicate that the majority of participants in the public and private schools have moderate anxiety and low confidence when they speak in foreign language with irresponsibility towards the EFL class. Noting that private school participants have more confidence and lower anxiety than those in the public school.

Table38. Q18. Anxiety post test results

\begin{tabular}{|c|c|c|c|c|c|c|c|}
\hline \multirow[t]{3}{*}{ School } & \multirow[t]{3}{*}{ Q18 } & \multicolumn{4}{|c|}{ Group } & \multicolumn{2}{|c|}{ Total } \\
\hline & & \multicolumn{2}{|c|}{ Experimental } & \multicolumn{2}{|c|}{ Control } & & \\
\hline & & $\mathrm{N}$ & $\%$ & $\mathrm{~N}$ & $\%$ & $\mathrm{~N}$ & $\%$ \\
\hline \multirow{6}{*}{ Public } & SA & 12 & $46.2 \%$ & 0 & & 12 & $24.5 \%$ \\
\hline & $\mathrm{A}$ & 12 & $46.2 \%$ & 1 & $4.3 \%$ & 13 & $26.5 \%$ \\
\hline & NAND & & & & & & \\
\hline & $\mathrm{DA}$ & 1 & $3.8 \%$ & 6 & $26.1 \%$ & 7 & $14.3 \%$ \\
\hline & SD & 1 & $3.8 \%$ & 16 & $69.6 \%$ & 17 & $34.7 \%$ \\
\hline & Total & 26 & $100.0 \%$ & 23 & $100.0 \%$ & 49 & $100.0 \%$ \\
\hline \multirow[t]{6}{*}{ Private } & $\mathrm{SA}$ & 11 & $40.7 \%$ & 3 & $12.5 \%$ & 14 & $27.5 \%$ \\
\hline & $\mathrm{A}$ & 15 & $55.6 \%$ & 8 & $33.3 \%$ & 23 & $45.1 \%$ \\
\hline & NAND & 1 & $3.7 \%$ & 4 & $16.7 \%$ & 5 & $9.8 \%$ \\
\hline & $\mathrm{DA}$ & 0 & & 3 & $12.5 \%$ & 3 & $5.9 \%$ \\
\hline & SD & 0 & & 6 & $25.0 \%$ & 6 & $11.8 \%$ \\
\hline & Total & 27 & $100.0 \%$ & 24 & $100.0 \%$ & 51 & $100.0 \%$ \\
\hline \multirow[t]{6}{*}{ Total } & SA & 23 & $43.4 \%$ & 3 & $6.4 \%$ & 26 & $26.0 \%$ \\
\hline & $\mathrm{A}$ & 27 & $50.9 \%$ & 9 & $19.1 \%$ & 36 & $36.0 \%$ \\
\hline & NAND & 1 & $1.9 \%$ & 4 & $8.5 \%$ & 5 & $5.0 \%$ \\
\hline & $\mathrm{DA}$ & 1 & $1.9 \%$ & 9 & $19.1 \%$ & 10 & $10.0 \%$ \\
\hline & SD & 1 & $1.9 \%$ & 22 & $46.8 \%$ & 23 & $23.0 \%$ \\
\hline & Total & 53 & $100.0 \%$ & 47 & $100.0 \%$ & 100 & $100.0 \%$ \\
\hline
\end{tabular}

Table 38 of the anxiety posttest revealed that $92.4 \%$ of the participants in the public experimental group of the school strongly agree and agree with that they feel confident when they speak in foreign language class, $0 \%$ of the participants neither agree nor disagree with the statement, and $7.6 \%$ of the participants disagree and strongly disagree respectively. While in the control group, $4.3 \%$ of the participants agree with that they feel confident when they speak in foreign language class, $0 \%$ of the participants neither agree nor disagree, and $95.7 \%$ disagree with the statement.

Whereas $96.3 \%$ of the participants in the private experimental group agree and strongly agree with that they feel confident when they speak in foreign language class, $3.7 \%$ neither agree nor disagree with the statement, and $0 \%$ of the participants disagree with it. While in the control group, $45.8 \%$ of the participants agree with, $16.7 \%$ neither agree nor disagree, and $37.5 \%$ disagree with the same statement. Such differences in the results between the control and experimental groups indicate that anxiety has dramatically decreased in the experimental groups and almost all the participants have more responsibility, motivation and self confidence towards learning foreign language.

Table39. Q19. Anxiety pre test

\begin{tabular}{|c|c|c|c|c|c|c|c|}
\hline \multirow[t]{3}{*}{ School } & \multirow[t]{3}{*}{ Q19 } & \multicolumn{4}{|c|}{ Group } & \multicolumn{2}{|c|}{ Total } \\
\hline & & \multicolumn{2}{|c|}{ Experimental } & \multicolumn{2}{|c|}{ Control } & & \\
\hline & & $\mathrm{N}$ & $\%$ & $\mathrm{~N}$ & $\%$ & $\mathrm{~N}$ & $\%$ \\
\hline \multirow[t]{6}{*}{ Public } & SA & 2 & $7.7 \%$ & 1 & $3.1 \%$ & 3 & $5.2 \%$ \\
\hline & $\mathrm{A}$ & 8 & $30.8 \%$ & 7 & $21.9 \%$ & 15 & $25.9 \%$ \\
\hline & NAND & 3 & $11.5 \%$ & 9 & $28.1 \%$ & 12 & $20.7 \%$ \\
\hline & DA & 9 & $34.6 \%$ & 11 & $34.4 \%$ & 20 & $34.5 \%$ \\
\hline & SD & 4 & $15.4 \%$ & 4 & $12.5 \%$ & 8 & $13.8 \%$ \\
\hline & Total & 26 & $100.0 \%$ & 32 & $100.0 \%$ & 58 & $100.0 \%$ \\
\hline \multirow[t]{4}{*}{ Private } & SA & 3 & $11.5 \%$ & 2 & $6.3 \%$ & 5 & $8.6 \%$ \\
\hline & A & 3 & $11.5 \%$ & 5 & $15.6 \%$ & 8 & $13.8 \%$ \\
\hline & NAND & 7 & $26.9 \%$ & 17 & $53.1 \%$ & 24 & $41.4 \%$ \\
\hline & DA & 10 & $38.5 \%$ & 5 & $15.6 \%$ & 15 & $25.9 \%$ \\
\hline
\end{tabular}




\begin{tabular}{|l|l|l|l|l|l|l|l|}
\hline & SD & 3 & $11.5 \%$ & 3 & $9.4 \%$ & 6 & $10.3 \%$ \\
\cline { 2 - 8 } & Total & 26 & $100.0 \%$ & 32 & $100.0 \%$ & 58 & $100.0 \%$ \\
\hline \multirow{5}{*}{ Total } & SA & 5 & $9.6 \%$ & 3 & $4.7 \%$ & 8 & $6.9 \%$ \\
\cline { 2 - 8 } & A & 11 & $21.2 \%$ & 12 & $18.8 \%$ & 23 & $19.8 \%$ \\
\cline { 2 - 8 } & NAND & 10 & $19.2 \%$ & 26 & $40.6 \%$ & 36 & $31.0 \%$ \\
\cline { 2 - 8 } & DA & 19 & $36.5 \%$ & 16 & $25.0 \%$ & 35 & $30.2 \%$ \\
\cline { 2 - 8 } & SD & 7 & $13.5 \%$ & 7 & $10.9 \%$ & 14 & $12.1 \%$ \\
\cline { 2 - 8 } & Total & 52 & $100.0 \%$ & 64 & $100.0 \%$ & 116 & $100.0 \%$ \\
\hline
\end{tabular}

Table 39 revealed that $31.3 \%$ of the public school participants strongly agree and agree that they are afraid that their foreign language teacher is ready to correct every mistake they make, $20.7 \%$ neither agree nor disagree, and $48.3 \%$ disagree and strongly disagree respectively with the statement, whereas $22.4 \%$ of the private school participants agree and strongly disagree, $41.4 \%$ neither agree nor disagree, and $36.2 \%$ disagree and strongly disagree with the same statement. Such results indicate that the majority of the participants in the public and private schools are irresponsible towards the EFL and have no motivation towards learning a new language with moderate anxiety that makes them afraid of the teacher's correction.

Table40. Q19. Anxiety post test results

\begin{tabular}{|c|c|c|c|c|c|c|c|}
\hline \multirow[t]{3}{*}{ School } & \multirow[t]{3}{*}{ Q19 } & \multicolumn{4}{|c|}{ Group } & \multicolumn{2}{|c|}{ Total } \\
\hline & & \multicolumn{2}{|c|}{ Experimental } & \multicolumn{2}{|c|}{ Control } & & \\
\hline & & $\mathrm{N}$ & $\%$ & $\mathrm{~N}$ & $\%$ & $\mathrm{~N}$ & $\%$ \\
\hline \multirow[t]{6}{*}{ Public } & SA & 0 & & 8 & $38.1 \%$ & 8 & $17.0 \%$ \\
\hline & $\mathrm{A}$ & 4 & $15.4 \%$ & 10 & $47.6 \%$ & 14 & $29.8 \%$ \\
\hline & NAND & 8 & $30.8 \%$ & 2 & $9.5 \%$ & 10 & $21.3 \%$ \\
\hline & DA & 12 & $46.2 \%$ & 1 & $4.8 \%$ & 13 & $27.7 \%$ \\
\hline & SD & 2 & $7.7 \%$ & 0 & & 2 & $4.3 \%$ \\
\hline & Total & 26 & $100.0 \%$ & 21 & $100.0 \%$ & 47 & $100.0 \%$ \\
\hline \multirow[t]{6}{*}{ Private } & $\mathrm{SA}$ & 0 & & 2 & $8.3 \%$ & 2 & $3.9 \%$ \\
\hline & $\mathrm{A}$ & 3 & $11.1 \%$ & 5 & $20.8 \%$ & 8 & $15.7 \%$ \\
\hline & NAND & 10 & $37.0 \%$ & 6 & $25.0 \%$ & 16 & $31.4 \%$ \\
\hline & DA & 12 & $44.4 \%$ & 7 & $29.2 \%$ & 19 & $37.3 \%$ \\
\hline & SD & 2 & $7.4 \%$ & 4 & $16.7 \%$ & 6 & $11.8 \%$ \\
\hline & Total & 27 & $100.0 \%$ & 24 & $100.0 \%$ & 51 & $100.0 \%$ \\
\hline \multirow[t]{6}{*}{ Total } & $\mathrm{SA}$ & 0 & & 10 & $22.2 \%$ & 10 & $10.2 \%$ \\
\hline & A & 7 & $13.2 \%$ & 15 & $33.3 \%$ & 22 & $22.4 \%$ \\
\hline & NAND & 18 & $34.0 \%$ & 8 & $17.8 \%$ & 26 & $26.5 \%$ \\
\hline & $\mathrm{DA}$ & 24 & $45.3 \%$ & 8 & $17.8 \%$ & 32 & $32.7 \%$ \\
\hline & SD & 4 & $7.5 \%$ & 4 & $8.9 \%$ & 8 & $8.2 \%$ \\
\hline & Total & 53 & $100.0 \%$ & 45 & $100.0 \%$ & 98 & $100.0 \%$ \\
\hline
\end{tabular}

Table 40 of the anxiety posttest revealed that $15.4 \%$ of the participants in the public experimental group agree with that they are afraid that their foreign language teacher is ready to correct every mistake they make, $30.8 \%$ of the participants neither agree nor disagree with the statement, and $53.9 \%$ of the participants disagree and strongly disagree respectively. While in the control group, $85.7 \%$ of the participants agree and strongly agree respectively $9 \%$ of the participants neither agree nor disagree with it, and $4.8 \%$ disagree with the with the same statement.

Whereas $11.1 \%$ of the participants in the private experimental group agree with the tested statement, $37 \%$ neither agree nor disagree, and $51.8 \%$ of the participants disagree with the statement, while in the control group, $29.1 \%$ of the participants agree, $25 \%$ neither agree nor disagree, and $45.9 \%$ disagree with the same statement. Such differences in the results between the control and experimental groups indicate that anxiety has dramatically decreased in the experimental groups and almost all the participants became fearless from the teacher's evaluation and correction of mistakes, more motivated and confident towards the foreign language after implementing the CLL approach.

Table41. Q20. Anxiety pre test

\begin{tabular}{|l|l|l|l|l|l|l|l|}
\hline \multirow{3}{*}{ School } & Q20 & \multicolumn{2}{l|}{ Group } & \multicolumn{2}{l|}{ Total } \\
\cline { 2 - 8 } & \multicolumn{3}{|l|}{ Experimental } & Control & & \\
\cline { 2 - 8 } & & $\mathrm{N}$ & $\%$ & $\mathrm{~N}$ & $\%$ & $\mathrm{~N}$ & $\%$ \\
\hline \multirow{3}{*}{ Public } & SA & 3 & $11.5 \%$ & 2 & $6.3 \%$ & 5 & $8.6 \%$ \\
\cline { 2 - 8 } & $\mathrm{A}$ & 7 & $26.9 \%$ & 7 & $21.9 \%$ & 14 & $24.1 \%$ \\
\cline { 2 - 9 } & NAND & 6 & $23.1 \%$ & 13 & $40.6 \%$ & 19 & $32.8 \%$ \\
\hline
\end{tabular}


Could Cll Approach be a Remedy for Tripoli Secondary Students Speaking Skills?

\begin{tabular}{|c|l|l|l|l|l|l|l|}
\hline \multicolumn{1}{|c|}{} & DA & 7 & $26.9 \%$ & 8 & $25.0 \%$ & 15 & $25.9 \%$ \\
\cline { 2 - 8 } & SD & 3 & $11.5 \%$ & 2 & $6.3 \%$ & 5 & $8.6 \%$ \\
\cline { 2 - 8 } & Total & 26 & $100.0 \%$ & 32 & $100.0 \%$ & 58 & $100.0 \%$ \\
\hline \multirow{5}{*}{ Private } & SA & 4 & $15.4 \%$ & 0 & & 4 & $6.9 \%$ \\
\cline { 2 - 8 } & A & 2 & $7.7 \%$ & 0 & & 2 & $3.4 \%$ \\
\cline { 2 - 8 } & NAND & 0 & & 5 & $15.6 \%$ & 5 & $8.6 \%$ \\
\cline { 2 - 8 } & DA & 9 & $34.6 \%$ & 7 & $21.9 \%$ & 16 & $27.6 \%$ \\
\cline { 2 - 8 } & SD & 11 & $42.3 \%$ & 20 & $62.5 \%$ & 31 & $53.4 \%$ \\
\cline { 2 - 8 } & Total & 26 & $100.0 \%$ & 32 & $100.0 \%$ & 58 & $100.0 \%$ \\
\hline \multirow{5}{*}{ Sotal } & SA & 7 & $13.5 \%$ & 2 & $3.1 \%$ & 9 & $7.8 \%$ \\
\cline { 2 - 8 } & A & 9 & $17.3 \%$ & 7 & $10.9 \%$ & 16 & $13.8 \%$ \\
\cline { 2 - 8 } & NAND & 6 & $11.5 \%$ & 18 & $28.1 \%$ & 24 & $20.7 \%$ \\
\cline { 2 - 8 } & DA & 16 & $30.8 \%$ & 15 & $23.4 \%$ & 31 & $26.7 \%$ \\
\cline { 2 - 8 } & SD & 14 & $26.9 \%$ & 22 & $34.4 \%$ & 36 & $31.0 \%$ \\
\cline { 2 - 8 } & Total & 52 & $100.0 \%$ & 64 & $100.0 \%$ & 116 & $100.0 \%$ \\
\hline
\end{tabular}

Table 41 disclosed that $32.7 \%$ of the public school participants strongly agree and agree that they can feel their heart pounding when they are going to be called on in foreign language class, $32.8 \%$ neither agree nor disagree, and $34.5 \%$ disagree and strongly disagree respectively with the statement while $10.3 \%$ of the private school participants agree and strongly disagree, $8.6 \%$ neither agree nor disagree, and $81 \%$ disagree and strongly disagree with the same statement. Such results indicate that the majority of the participants in the public school have moderate anxiety level, low self confidence and irresponsibility towards the EFL class. Whereas the majority of the private school students have high confidence in the EFL, low anxiety level and responsibility towards the EFL class.

Table42. Q20. Anxiety post test results

\begin{tabular}{|c|c|c|c|c|c|c|c|}
\hline \multirow[t]{3}{*}{ School } & \multirow[t]{3}{*}{ Q20 } & \multicolumn{4}{|c|}{ Group } & \multicolumn{2}{|c|}{ Total } \\
\hline & & \multicolumn{2}{|c|}{ Experimental } & \multicolumn{2}{|c|}{ Control } & & \\
\hline & & $\mathrm{N}$ & $\%$ & $\mathrm{~N}$ & $\%$ & $\mathrm{~N}$ & $\%$ \\
\hline \multirow[t]{6}{*}{ Public } & SA & 0 & & 10 & $43.5 \%$ & 10 & $20.4 \%$ \\
\hline & $\mathrm{A}$ & 0 & & 10 & $43.5 \%$ & 10 & $20.4 \%$ \\
\hline & NAND & 0 & & 1 & $4.3 \%$ & 1 & $2.0 \%$ \\
\hline & DA & 5 & $19.2 \%$ & 1 & $4.3 \%$ & 6 & $12.2 \%$ \\
\hline & SD & 21 & $80.8 \%$ & 1 & $4.3 \%$ & 22 & $44.9 \%$ \\
\hline & Total & 26 & $100.0 \%$ & 23 & $100.0 \%$ & 49 & $100.0 \%$ \\
\hline \multirow[t]{6}{*}{ Private } & SA & 0 & & 1 & $4.2 \%$ & 1 & $2.0 \%$ \\
\hline & A & 0 & & 1 & $4.2 \%$ & 1 & $2.0 \%$ \\
\hline & NAND & 0 & & 3 & $12.5 \%$ & 3 & $5.9 \%$ \\
\hline & DA & 6 & $22.2 \%$ & 7 & $29.2 \%$ & 13 & $25.5 \%$ \\
\hline & SD & 21 & $77.8 \%$ & 12 & $50.0 \%$ & 33 & $64.7 \%$ \\
\hline & Total & 27 & $100.0 \%$ & 24 & $100.0 \%$ & 51 & $100.0 \%$ \\
\hline \multirow[t]{6}{*}{ Total } & SA & 0 & & 11 & $23.4 \%$ & 11 & $11.0 \%$ \\
\hline & A & 0 & & 11 & $23.4 \%$ & 11 & $11.0 \%$ \\
\hline & NAND & 0 & & 4 & $8.5 \%$ & 4 & $4.0 \%$ \\
\hline & DA & 11 & $20.8 \%$ & 8 & $17.0 \%$ & 19 & $19.0 \%$ \\
\hline & SD & 42 & $79.2 \%$ & 13 & $27.7 \%$ & 55 & $55.0 \%$ \\
\hline & Total & 53 & $100.0 \%$ & 47 & $100.0 \%$ & 100 & $100.0 \%$ \\
\hline
\end{tabular}

Table 42 of the anxiety posttest revealed that $0 \%$ of the participants in the public experimental group strongly agree and agree with that they can feel their heart pounding when they are going to be called on in foreign language class, $0 \%$ of the participants neither agree nor disagree, and $100 \%$ of the participants disagree and strongly disagree with the statement respectively, while in the control group, $87 \%$ of the participants agree and strongly agree, $4.3 \%$ of the participants neither agree nor disagree with it, and $8.6 \%$ disagree with it.

Whereas $0 \%$ of the participants in the private experimental group agree and strongly agree with the tested statement, $0 \%$ neither agree nor disagree with the statement, and $100 \%$ of the participants disagree with it, while in the control group, $8.4 \%$ of the participants agree, $12.5 \%$ neither agree nor disagree, and $79.2 \%$ disagree with it. Such differences in the results between the control and experimental groups indicate that anxiety has dramatically and totally decreased in the experimental groups after implementing the CLL approach, and almost all the participants have more responsibility, motivation and self confidence towards learning foreign language. Surprisingly, the anxiety level also decreased in the control group of the private school at the end of the year. 
Table43. Q21. Anxiety pre test

\begin{tabular}{|c|c|c|c|c|c|c|c|}
\hline \multirow[t]{3}{*}{ School } & \multirow[t]{3}{*}{$\mathbf{Q 2 1}$} & \multicolumn{4}{|c|}{ Group } & \multicolumn{2}{|c|}{ Total } \\
\hline & & \multicolumn{2}{|c|}{ Experimental } & \multicolumn{2}{|c|}{ Control } & & \\
\hline & & $\mathrm{N}$ & $\%$ & $\mathrm{~N}$ & $\%$ & $\mathrm{~N}$ & $\%$ \\
\hline \multirow[t]{6}{*}{ Public } & SA & 2 & $7.7 \%$ & 4 & $12.5 \%$ & 6 & $10.3 \%$ \\
\hline & $\mathrm{A}$ & 4 & $15.4 \%$ & 4 & $12.5 \%$ & 8 & $13.8 \%$ \\
\hline & NAND & 5 & $19.2 \%$ & 4 & $12.5 \%$ & 9 & $15.5 \%$ \\
\hline & $\mathrm{DA}$ & 11 & $42.3 \%$ & 16 & $50.0 \%$ & 27 & $46.6 \%$ \\
\hline & SD & 4 & $15.4 \%$ & 4 & $12.5 \%$ & 8 & $13.8 \%$ \\
\hline & Total & 26 & $100.0 \%$ & 32 & $100.0 \%$ & 58 & $100.0 \%$ \\
\hline \multirow[t]{6}{*}{ Private } & SA & 3 & $11.5 \%$ & 3 & $9.4 \%$ & 6 & $10.3 \%$ \\
\hline & A & 1 & $3.8 \%$ & 1 & $3.1 \%$ & 2 & $3.4 \%$ \\
\hline & NAND & 9 & $34.6 \%$ & 10 & $31.3 \%$ & 19 & $32.8 \%$ \\
\hline & $\mathrm{DA}$ & 8 & $30.8 \%$ & 10 & $31.3 \%$ & 18 & $31.0 \%$ \\
\hline & SD & 5 & $19.2 \%$ & 8 & $25.0 \%$ & 13 & $22.4 \%$ \\
\hline & Total & 26 & $100.0 \%$ & 32 & $100.0 \%$ & 58 & $100.0 \%$ \\
\hline \multirow[t]{6}{*}{ Total } & $\mathrm{SA}$ & 5 & $9.6 \%$ & 7 & $10.9 \%$ & 12 & $10.3 \%$ \\
\hline & A & 5 & $9.6 \%$ & 5 & $7.8 \%$ & 10 & $8.6 \%$ \\
\hline & NAND & 14 & $26.9 \%$ & 14 & $21.9 \%$ & 28 & $24.1 \%$ \\
\hline & DA & 19 & $36.5 \%$ & 26 & $40.6 \%$ & 45 & $38.8 \%$ \\
\hline & SD & 9 & $17.3 \%$ & 12 & $18.8 \%$ & 21 & $18.1 \%$ \\
\hline & Total & 52 & $100.0 \%$ & 64 & $100.0 \%$ & 116 & $100.0 \%$ \\
\hline
\end{tabular}

Table 43 revealed that $24.1 \%$ of the public school participants strongly agree and agree that the more they study for a foreign language test, the more confused they get, $15.5 \%$ neither agree nor disagree with it, and $60.4 \%$ disagree and strongly disagree respectively with the statement, while $13.7 \%$ of the private school participants agree and strongly agree, $32.8 \%$ neither agree nor disagree, and $53.4 \%$ disagree and strongly disagree with the same statement. Such results indicate that the majority of the participants in the public and private schools have low anxiety when they are well prepared and that they need to study well for the EFL test. Moreover, a good number of participants have moderate anxiety, irresponsibility and low self confidence towards the EFL class.

Table44. Q21. Anxiety post test results

\begin{tabular}{|c|c|c|c|c|c|c|c|}
\hline \multirow[t]{3}{*}{ School } & \multirow[t]{3}{*}{ Q21 } & \multicolumn{4}{|c|}{ Group } & \multicolumn{2}{|c|}{ Total } \\
\hline & & \multicolumn{2}{|c|}{ Experimental } & \multicolumn{2}{|c|}{ Control } & & \\
\hline & & $\mathrm{N}$ & $\%$ & $\mathrm{~N}$ & $\%$ & $\mathrm{~N}$ & $\%$ \\
\hline \multirow{6}{*}{ Public } & SA & 0 & & 4 & $17.4 \%$ & 4 & $8.2 \%$ \\
\hline & $\mathrm{A}$ & 0 & & 10 & $43.5 \%$ & 10 & $20.4 \%$ \\
\hline & NAND & 1 & $3.8 \%$ & 7 & $30.4 \%$ & 8 & $16.3 \%$ \\
\hline & DA & 15 & $57.7 \%$ & 2 & $8.7 \%$ & 17 & $34.7 \%$ \\
\hline & $\mathrm{SD}$ & 10 & $38.5 \%$ & 0 & & 10 & $20.4 \%$ \\
\hline & Total & 26 & $100.0 \%$ & 23 & $100.0 \%$ & 49 & $100.0 \%$ \\
\hline \multirow[t]{6}{*}{ Private } & SA & & & & & & \\
\hline & A & 1 & $3.7 \%$ & 2 & $8.3 \%$ & 3 & $5.9 \%$ \\
\hline & NAND & 3 & $11.1 \%$ & 7 & $29.2 \%$ & 10 & $19.6 \%$ \\
\hline & DA & 18 & $66.7 \%$ & 8 & $33.3 \%$ & 26 & $51.0 \%$ \\
\hline & SD & 5 & $18.5 \%$ & 7 & $29.2 \%$ & 12 & $23.5 \%$ \\
\hline & Total & 27 & $100.0 \%$ & 24 & $100.0 \%$ & 51 & $100.0 \%$ \\
\hline \multirow[t]{6}{*}{ Total } & $\mathrm{SA}$ & 0 & & 4 & $8.5 \%$ & 4 & $4.0 \%$ \\
\hline & $\mathrm{A}$ & 1 & $1.9 \%$ & 12 & $25.5 \%$ & 13 & $13.0 \%$ \\
\hline & NAND & 4 & $7.5 \%$ & 14 & $29.8 \%$ & 18 & $18.0 \%$ \\
\hline & DA & 33 & $62.3 \%$ & 10 & $21.3 \%$ & 43 & $43.0 \%$ \\
\hline & SD & 15 & $28.3 \%$ & 7 & $14.9 \%$ & 22 & $22.0 \%$ \\
\hline & Total & 53 & $100.0 \%$ & 47 & $100.0 \%$ & 100 & $100.0 \%$ \\
\hline
\end{tabular}

Table 44 of the anxiety posttest revealed that $0 \%$ of the participants in the experimental group of the public school strongly agree and agree with that the more they study for a foreign language test, the more confused they get, $3.8 \%$ of the participants neither agree nor disagree with the statement, and $96.2 \%$ of the participants disagree and strongly disagree respectively, while in the control group, $60.9 \%$ of the participants agree and strongly agree, $30.4 \%$ of the participants neither agree nor disagree, and $8.7 \%$ disagree with the same statement. Whereas $3.7 \%$ of the participants in the private experimental group agree with the tested statement, $11.1 \%$ neither agree nor disagree, and $84.2 \%$ of the participants disagree with it, while in the control group, $8.3 \%$ of the participants agree, $29.2 \%$ 
neither agree nor disagree, and $62.5 \%$ disagree with the same statement. Such differences in the results between the control and experimental groups indicate that anxiety has dramatically decreased in the experimental groups and almost all the participants have more responsibility and self confidence towards EFL test. Noting that at the end of the year the participants in the control group of the private school had low anxiety and more confidence in themselves when they are well prepared for the EFL test.

Table45. Q22. Anxiety pre test

\begin{tabular}{|c|c|c|c|c|c|c|c|}
\hline \multirow{3}{*}{ School } & \multirow{3}{*}{ Q22.I } & \multicolumn{4}{|c|}{ Group } & \multicolumn{2}{|c|}{ Total } \\
\hline & & \multicolumn{2}{|c|}{ Experimental } & \multicolumn{2}{|c|}{ Control } & & \\
\hline & & $\mathrm{N}$ & $\%$ & $\mathrm{~N}$ & $\%$ & $\mathrm{~N}$ & $\%$ \\
\hline \multirow[t]{6}{*}{ Public } & SA & 6 & $23.1 \%$ & 5 & $15.6 \%$ & 11 & $19.0 \%$ \\
\hline & A & 12 & $46.2 \%$ & 16 & $50.0 \%$ & 28 & $48.3 \%$ \\
\hline & NAND & 1 & $3.8 \%$ & 9 & $28.1 \%$ & 10 & $17.2 \%$ \\
\hline & $\mathrm{DA}$ & 6 & $23.1 \%$ & 1 & $3.1 \%$ & 7 & $12.1 \%$ \\
\hline & SD & 1 & $3.8 \%$ & 1 & $3.1 \%$ & 2 & $3.4 \%$ \\
\hline & Total & 26 & $100.0 \%$ & 32 & $100.0 \%$ & 58 & $100.0 \%$ \\
\hline \multirow[t]{6}{*}{ Private } & SA & 5 & $19.2 \%$ & 12 & $37.5 \%$ & 17 & $29.3 \%$ \\
\hline & A & 7 & $26.9 \%$ & 3 & $9.4 \%$ & 10 & $17.2 \%$ \\
\hline & NAND & 5 & $19.2 \%$ & 3 & $9.4 \%$ & 8 & $13.8 \%$ \\
\hline & DA & 6 & $23.1 \%$ & 11 & $34.4 \%$ & 17 & $29.3 \%$ \\
\hline & SD & 3 & $11.5 \%$ & 3 & $9.4 \%$ & 6 & $10.3 \%$ \\
\hline & Total & 26 & $100.0 \%$ & 32 & $100.0 \%$ & 58 & $100.0 \%$ \\
\hline \multirow[t]{6}{*}{ Total } & SA & 11 & $21.2 \%$ & 17 & $26.6 \%$ & 28 & $24.1 \%$ \\
\hline & A & 19 & $36.5 \%$ & 19 & $29.7 \%$ & 38 & $32.8 \%$ \\
\hline & NAND & 6 & $11.5 \%$ & 12 & $18.8 \%$ & 18 & $15.5 \%$ \\
\hline & DA & 12 & $23.1 \%$ & 12 & $18.8 \%$ & 24 & $20.7 \%$ \\
\hline & SD & 4 & $7.7 \%$ & 4 & $6.3 \%$ & 8 & $6.9 \%$ \\
\hline & Total & 52 & $100.0 \%$ & 64 & $100.0 \%$ & 116 & $100.0 \%$ \\
\hline
\end{tabular}

Table 45 revealed that $67.3 \%$ of the public school participants strongly agree and agree that they don't feel pressure to prepare very well for foreign language class, $17.2 \%$ neither agree nor disagree, and $15.5 \%$ disagree and strongly disagree respectively with the statement, whereas $46.5 \%$ of the private school participants agree and strongly disagree, $13.8 \%$ neither agree nor disagree, and $39.6 \%$ disagree and strongly disagree with the same statement. Such results indicate that the majority of the participants in both sectors schools are irresponsible towards the EFL and have no motivation towards preparing for the EFL class.

Table46. Q22. Anxiety post test results

\begin{tabular}{|c|c|c|c|c|c|c|c|}
\hline \multirow[t]{3}{*}{ School } & \multirow[t]{3}{*}{ Q22.I } & \multicolumn{4}{|c|}{ Group } & \multicolumn{2}{|c|}{ Total } \\
\hline & & \multicolumn{2}{|c|}{ Experimental } & \multicolumn{2}{|c|}{ Control } & & \\
\hline & & $\mathrm{N}$ & $\%$ & $\mathrm{~N}$ & $\%$ & $\mathrm{~N}$ & $\%$ \\
\hline \multirow{6}{*}{ Public } & SA & 1 & $3.8 \%$ & 0 & & 1 & $2.0 \%$ \\
\hline & $\mathrm{A}$ & 6 & $23.1 \%$ & 1 & $4.3 \%$ & 7 & $14.3 \%$ \\
\hline & NAND & 9 & $34.6 \%$ & 2 & $8.7 \%$ & 11 & $22.4 \%$ \\
\hline & DA & 8 & $30.8 \%$ & 16 & $69.6 \%$ & 24 & $49.0 \%$ \\
\hline & SD & 2 & $7.7 \%$ & 4 & $17.4 \%$ & 6 & $12.2 \%$ \\
\hline & Total & 26 & $100.0 \%$ & 23 & $100.0 \%$ & 49 & $100.0 \%$ \\
\hline \multirow[t]{6}{*}{ Private } & $\mathrm{SA}$ & 0 & & 4 & $16.7 \%$ & 4 & $7.8 \%$ \\
\hline & A & 11 & $40.7 \%$ & 7 & $29.2 \%$ & 18 & $35.3 \%$ \\
\hline & NAND & 11 & $40.7 \%$ & 3 & $12.5 \%$ & 14 & $27.5 \%$ \\
\hline & DA & 5 & $18.5 \%$ & 8 & $33.3 \%$ & 13 & $25.5 \%$ \\
\hline & SD & 0 & & 2 & $8.3 \%$ & 2 & $3.9 \%$ \\
\hline & Total & 27 & $100.0 \%$ & 24 & $100.0 \%$ & 51 & $100.0 \%$ \\
\hline \multirow[t]{6}{*}{ Total } & $\mathrm{SA}$ & 1 & $1.9 \%$ & 4 & $8.5 \%$ & 5 & $5.0 \%$ \\
\hline & $\mathrm{A}$ & 17 & $32.1 \%$ & 8 & $17.0 \%$ & 25 & $25.0 \%$ \\
\hline & NAND & 20 & $37.7 \%$ & 5 & $10.6 \%$ & 25 & $25.0 \%$ \\
\hline & DA & 13 & $24.5 \%$ & 24 & $51.1 \%$ & 37 & $37.0 \%$ \\
\hline & SD & 2 & $3.8 \%$ & 6 & $12.8 \%$ & 8 & $8.0 \%$ \\
\hline & Total & 53 & $100.0 \%$ & 47 & $100.0 \%$ & 100 & $100.0 \%$ \\
\hline
\end{tabular}

Table 46 of the anxiety posttest showed that $26.9 \%$ of the participants in the public experimental group strongly agree and agree with that they don't feel pressure to prepare very well for foreign language class, $34.6 \%$ of the participants neither agree nor disagree, and $38.5 \%$ of the participants 
disagree and strongly disagree with the statement respectively, while in the control group, $4.3 \%$ of the participants agree, $8.7 \%$ of the participants neither agree nor disagree, and $87 \%$ disagree with the same statement. Whereas $40.7 \%$ of the participants in the private experimental group agree with that they don't feel pressure to prepare very well for foreign language class, $40.7 \%$ neither agree nor disagree, and $18.5 \%$ of the participants disagree, while in the control group, $45.4 \%$ of the participants agree, $12.5 \%$ neither agree nor disagree, and $41.6 \%$ disagree with the statement.

Such differences in the results between the control and experimental groups indicate that after applying the CLL approach, the participants in the public school have more responsibility and motivation towards the learning of EFL whereas the participants in the private school still have irresponsibility towards preparing well for the foreign language class.

Table47. Q23. Anxiety pre test

\begin{tabular}{|c|c|c|c|c|c|c|c|}
\hline \multirow[t]{3}{*}{ School } & \multirow[t]{3}{*}{ Q23.I } & \multicolumn{4}{|c|}{ Group } & \multicolumn{2}{|c|}{ Total } \\
\hline & & \multicolumn{2}{|c|}{ Experimental } & \multicolumn{2}{|c|}{ Control } & & \\
\hline & & $\mathrm{N}$ & $\%$ & $\mathrm{~N}$ & $\%$ & $\mathrm{~N}$ & $\%$ \\
\hline \multirow{6}{*}{ Public } & SA & 5 & $19.2 \%$ & 4 & $12.5 \%$ & 9 & $15.5 \%$ \\
\hline & $\mathrm{A}$ & 9 & $34.6 \%$ & 7 & $21.9 \%$ & 16 & $27.6 \%$ \\
\hline & NAND & 9 & $34.6 \%$ & 11 & $34.4 \%$ & 20 & $34.5 \%$ \\
\hline & DA & 2 & $7.7 \%$ & 8 & $25.0 \%$ & 10 & $17.2 \%$ \\
\hline & $\mathrm{SD}$ & 1 & $3.8 \%$ & 2 & $6.3 \%$ & 3 & $5.2 \%$ \\
\hline & Total & 26 & $100.0 \%$ & 32 & $100.0 \%$ & 58 & $100.0 \%$ \\
\hline \multirow[t]{6}{*}{ Private } & $\mathrm{SA}$ & 3 & $12.0 \%$ & 1 & $3.1 \%$ & 4 & $7.0 \%$ \\
\hline & A & 4 & $16.0 \%$ & 12 & $37.5 \%$ & 16 & $28.1 \%$ \\
\hline & NAND & 7 & $28.0 \%$ & 8 & $25.0 \%$ & 15 & $26.3 \%$ \\
\hline & DA & 8 & $32.0 \%$ & 7 & $21.9 \%$ & 15 & $26.3 \%$ \\
\hline & SD & 3 & $12.0 \%$ & 4 & $12.5 \%$ & 7 & $12.3 \%$ \\
\hline & Total & 25 & $100.0 \%$ & 32 & $100.0 \%$ & 57 & $100.0 \%$ \\
\hline \multirow[t]{6}{*}{ Total } & $\mathrm{SA}$ & 8 & $15.7 \%$ & 5 & $7.8 \%$ & 13 & $11.3 \%$ \\
\hline & $\mathrm{A}$ & 13 & $25.5 \%$ & 19 & $29.7 \%$ & 32 & $27.8 \%$ \\
\hline & NAND & 16 & $31.4 \%$ & 19 & $29.7 \%$ & 35 & $30.4 \%$ \\
\hline & $\mathrm{DA}$ & 10 & $19.6 \%$ & 15 & $23.4 \%$ & 25 & $21.7 \%$ \\
\hline & SD & 4 & $7.8 \%$ & 6 & $9.4 \%$ & 10 & $8.7 \%$ \\
\hline & Total & 51 & $100.0 \%$ & 64 & $100.0 \%$ & 115 & $100.0 \%$ \\
\hline
\end{tabular}

Table 47 revealed that $43.1 \%$ of the public school participants strongly agree and agree that they always feel that the other students speak the foreign language better than they do, $34.5 \%$ neither agree nor disagree, and $22.4 \%$ disagree and strongly disagree respectively with the statement, whereas $35.1 \%$ of the private school participants agree and strongly agree, $26.3 \%$ neither agree nor disagree, and $38.6 \%$ disagree and strongly disagree with the statement. Such results indicate that the majority of the participants in the public and private schools are irresponsible towards the EFL, have low confidence in themselves and high anxiety that makes them feel that other students speak the FL better than they do, especially in the public school.

Table48. Q23. Anxiety post test results

\begin{tabular}{|c|c|c|c|c|c|c|c|}
\hline \multirow[t]{3}{*}{ School } & Q23.I & \multicolumn{4}{|c|}{ Group } & \multicolumn{2}{|c|}{ Total } \\
\hline & & \multicolumn{2}{|c|}{ Experimental } & \multicolumn{2}{|c|}{ Control } & & \\
\hline & & $\mathrm{N}$ & $\%$ & $\mathrm{~N}$ & $\%$ & $\mathrm{~N}$ & $\%$ \\
\hline \multirow[t]{6}{*}{ Public } & SA & 0 & & 11 & $47.8 \%$ & 11 & $22.4 \%$ \\
\hline & A & 3 & $11.5 \%$ & 11 & $47.8 \%$ & 14 & $28.6 \%$ \\
\hline & NAND & 6 & $23.1 \%$ & 1 & $4.3 \%$ & 7 & $14.3 \%$ \\
\hline & DA & 14 & $53.8 \%$ & 0 & & 14 & $28.6 \%$ \\
\hline & SD & 3 & $11.5 \%$ & 0 & & 3 & $6.1 \%$ \\
\hline & Total & 26 & $100.0 \%$ & 23 & $100.0 \%$ & 49 & $100.0 \%$ \\
\hline \multirow[t]{6}{*}{ Private } & $\mathrm{SA}$ & 0 & & 3 & $12.5 \%$ & 3 & $5.9 \%$ \\
\hline & $\mathrm{A}$ & 0 & & 4 & $16.7 \%$ & 4 & $7.8 \%$ \\
\hline & NAND & 0 & & 7 & $29.2 \%$ & 7 & $13.7 \%$ \\
\hline & $\mathrm{DA}$ & 16 & $59.3 \%$ & 7 & $29.2 \%$ & 23 & $45.1 \%$ \\
\hline & SD & 11 & $40.7 \%$ & 3 & $12.5 \%$ & 14 & $27.5 \%$ \\
\hline & Total & 27 & $100.0 \%$ & 24 & $100.0 \%$ & 51 & $100.0 \%$ \\
\hline \multirow[t]{4}{*}{ Total } & $\mathrm{SA}$ & 0 & & 14 & $29.8 \%$ & 14 & $14.0 \%$ \\
\hline & A & 3 & $5.7 \%$ & 15 & $31.9 \%$ & 18 & $18.0 \%$ \\
\hline & NAND & 6 & $11.3 \%$ & 8 & $17.0 \%$ & 14 & $14.0 \%$ \\
\hline & $\mathrm{DA}$ & 30 & $56.6 \%$ & 7 & $14.9 \%$ & 37 & $37.0 \%$ \\
\hline
\end{tabular}




\begin{tabular}{|l|l|l|l|l|l|l|l|}
\hline & SD & 14 & $26.4 \%$ & 3 & $6.4 \%$ & 17 & $17.0 \%$ \\
\cline { 2 - 8 } & Total & 53 & $100.0 \%$ & 47 & $100.0 \%$ & 100 & $100.0 \%$ \\
\hline
\end{tabular}

Table 48 of the anxiety posttest results indicated that $11.5 \%$ of the participants in the public experimental group agree with that they always feel that the other students speak the foreign language better than they do, $23.1 \%$ of the participants neither agree nor disagree with the statement, and $65.3 \%$ of the participants disagree and strongly disagree respectively, while in the control group, $95.6 \%$ of the participants agree and strongly agree, $4.3 \%$ of the participants neither agree nor disagree, and $0 \%$ disagree with the same statement. Whereas $0 \%$ of the participants in the private experimental group agree and strongly agree with the tested statement, $0 \%$ neither agree nor disagree with the statement, and $100 \%$ of the participants disagree, while in the control group, $29.2 \%$ of the participants agree, $29.2 \%$ neither agree nor disagree, and $41.7 \%$ disagree with it. Such differences in the results between the control and experimental groups indicate that anxiety has dramatically decreased in the experimental groups and almost all the participants have more responsibility, more motivation to speak the EFL and self confidence towards learning foreign language after implementing CLL. Noting that the experimental group of the private school outperform the public one.

Table49. Q24. Anxiety pre test

\begin{tabular}{|c|c|c|c|c|c|c|c|}
\hline \multirow[t]{3}{*}{ School } & \multirow[t]{3}{*}{ Q24 } & \multicolumn{4}{|c|}{ Group } & \multicolumn{2}{|c|}{ Total } \\
\hline & & \multicolumn{2}{|c|}{ Experimental } & \multicolumn{2}{|c|}{ Control } & & \\
\hline & & $\mathrm{N}$ & $\%$ & $\mathrm{~N}$ & $\%$ & $\mathrm{~N}$ & $\%$ \\
\hline \multirow{6}{*}{ Public } & Strongly agree & 1 & $3.8 \%$ & 0 & & 1 & $1.7 \%$ \\
\hline & Agree & 10 & $38.5 \%$ & 12 & $37.5 \%$ & 22 & $37.9 \%$ \\
\hline & $\begin{array}{lll}\begin{array}{l}\text { Neither } \\
\text { disagree }\end{array} & \text { agree nor } \\
\end{array}$ & 6 & $23.1 \%$ & 12 & $37.5 \%$ & 18 & $31.0 \%$ \\
\hline & Disagree & 7 & $26.9 \%$ & 7 & $21.9 \%$ & 14 & $24.1 \%$ \\
\hline & Strongly disagree & 2 & $7.7 \%$ & 1 & $3.1 \%$ & 3 & $5.2 \%$ \\
\hline & Total & 26 & $100.0 \%$ & 32 & $100.0 \%$ & 58 & $100.0 \%$ \\
\hline \multirow[t]{6}{*}{ Private } & Strongly agree & 7 & $28.0 \%$ & 18 & $56.3 \%$ & 25 & $43.9 \%$ \\
\hline & Agree & 3 & $12.0 \%$ & 4 & $12.5 \%$ & 7 & $12.3 \%$ \\
\hline & $\begin{array}{lll}\text { Neither agree nor } \\
\text { disagree }\end{array}$ & 3 & $12.0 \%$ & 2 & $6.3 \%$ & 5 & $8.8 \%$ \\
\hline & Disagree & 8 & $32.0 \%$ & 5 & $15.6 \%$ & 13 & $22.8 \%$ \\
\hline & Strongly disagree & 4 & $16.0 \%$ & 3 & $9.4 \%$ & 7 & $12.3 \%$ \\
\hline & Total & 25 & $100.0 \%$ & 32 & $100.0 \%$ & 57 & $100.0 \%$ \\
\hline \multirow[t]{6}{*}{ Total } & Strongly agree & 8 & $15.7 \%$ & 18 & $28.1 \%$ & 26 & $22.6 \%$ \\
\hline & Agree & 13 & $25.5 \%$ & 16 & $25.0 \%$ & 29 & $25.2 \%$ \\
\hline & $\begin{array}{lll}\begin{array}{l}\text { Neither } \\
\text { disagree }\end{array} & \text { agree nor } \\
\end{array}$ & 9 & $17.6 \%$ & 14 & $21.9 \%$ & 23 & $20.0 \%$ \\
\hline & Disagree & 15 & $29.4 \%$ & 12 & $18.8 \%$ & 27 & $23.5 \%$ \\
\hline & Strongly disagree & 6 & $11.8 \%$ & 4 & $6.3 \%$ & 10 & $8.7 \%$ \\
\hline & Total & 51 & $100.0 \%$ & 64 & $100.0 \%$ & 115 & $100.0 \%$ \\
\hline
\end{tabular}

Table 49 showed that $39.6 \%$ of the public school participants strongly agree and strongly agree that they feel very self- conscious about speaking the foreign language in front of other students, $31 \%$ neither agree nor disagree, and $29.3 \%$ disagree and strongly disagree respectively, whereas $56.2 \%$ of the private school participants agree and strongly agree, $8.8 \%$ neither agree nor disagree, and $35.1 \%$ disagree and strongly disagree with the same statement. Such results indicate that the majority of the participants in the public and private schools are irresponsible towards the EFL and have moderate anxiety that makes them not totally conscious about speaking the FL in front of other students. Noting that private school participants showed more responsibility, motivation and consciousness when speaking in front of others than the public participants.

Table50. Q24. Anxiety post test results

\begin{tabular}{|c|c|c|c|c|c|c|c|}
\hline \multirow[t]{3}{*}{ School } & \multirow[t]{3}{*}{ Q24.I } & \multicolumn{4}{|c|}{ Group } & \multicolumn{2}{|c|}{ Total } \\
\hline & & \multicolumn{2}{|c|}{ Experimental } & \multicolumn{2}{|c|}{ Control } & & \\
\hline & & $\mathrm{N}$ & $\%$ & $\mathrm{~N}$ & $\%$ & $\mathrm{~N}$ & $\%$ \\
\hline \multirow[t]{5}{*}{ Public } & SA & 0 & $0 \%$ & 0 & $0 \%$ & 0 & $0 \%$ \\
\hline & A & 14 & $53.8 \%$ & 7 & $30.4 \%$ & 21 & $42.9 \%$ \\
\hline & NAND & 9 & $34.6 \%$ & 8 & $34.8 \%$ & 17 & $34.7 \%$ \\
\hline & DA & 3 & $11.5 \%$ & 8 & $34.8 \%$ & 11 & $22.4 \%$ \\
\hline & SD & & & & & & \\
\hline
\end{tabular}


Could Cll Approach be a Remedy for Tripoli Secondary Students Speaking Skills?

\begin{tabular}{|l|l|l|l|l|l|l|l|}
\hline \multicolumn{9}{|c|}{} & Total & 26 & $100.0 \%$ & 23 & $100.0 \%$ & 49 & $100.0 \%$ \\
\hline \multirow{5}{*}{ Private } & SA & 0 & & 5 & $20.8 \%$ & 5 & $9.8 \%$ \\
\cline { 2 - 8 } & A & 17 & $63.0 \%$ & 5 & $20.8 \%$ & 22 & $43.1 \%$ \\
\cline { 2 - 8 } & NAND & 8 & $29.6 \%$ & 3 & $12.5 \%$ & 11 & $21.6 \%$ \\
\cline { 2 - 8 } & DA & 2 & $7.4 \%$ & 7 & $29.2 \%$ & 9 & $17.6 \%$ \\
\cline { 2 - 8 } & SD & 0 & & 4 & $16.7 \%$ & 4 & $7.8 \%$ \\
\cline { 2 - 8 } & Total & 27 & $100.0 \%$ & 24 & $100.0 \%$ & 51 & $100.0 \%$ \\
\hline \multirow{5}{*}{ Total } & SA & 0 & & 5 & $10.6 \%$ & 5 & $5.0 \%$ \\
\cline { 2 - 8 } & A & 31 & $58.5 \%$ & 12 & $25.5 \%$ & 43 & $43.0 \%$ \\
\cline { 2 - 8 } & NAND & 17 & $32.1 \%$ & 11 & $23.4 \%$ & 28 & $28.0 \%$ \\
\cline { 2 - 8 } & DA & 5 & $9.4 \%$ & 15 & $31.9 \%$ & 20 & $20.0 \%$ \\
\cline { 2 - 8 } & SD & 0 & & 4 & $8.5 \%$ & 4 & $4.0 \%$ \\
\cline { 2 - 8 } & Total & 53 & $100.0 \%$ & 47 & $100.0 \%$ & 100 & $100.0 \%$ \\
\hline
\end{tabular}

Table 50 of the anxiety posttest revealed that $53.8 \%$ of the participants in the public experimental group agree with that they feel very self- conscious about speaking the foreign language in front of other students, $34.6 \%$ of the participants neither agree nor disagree and $11.5 \%$ of the participants disagree, while in the control group, $30.4 \%$ of the participants agree, $34.8 \%$ of the participants neither agree nor disagree, and $34.8 \%$ disagree with the same statement. Whereas $63 \%$ of the participants in the private experimental group agree with the tested statement, $29.6 \%$ neither agree nor disagree with the statement, and $7.4 \%$ of the participants disagree, while in the control group, $41.6 \%$ of the participants agree, $12.5 \%$ neither agree nor disagree, and $45.9 \%$ disagree with it. Such differences in the results between the control and experimental groups indicate that anxiety has decreased in the experimental groups and almost all the participants have more responsibility, motivation, self conscious and self confidence towards speaking the foreign language in front of others.

Table51. Q25. Anxiety pre test

\begin{tabular}{|c|c|c|c|c|c|c|c|}
\hline \multirow[t]{3}{*}{ School } & \multirow[t]{3}{*}{025.} & \multicolumn{4}{|c|}{ Group } & \multicolumn{2}{|c|}{ Total } \\
\hline & & \multicolumn{2}{|c|}{ Experimental } & \multicolumn{2}{|c|}{ Control } & & \\
\hline & & $\mathrm{N}$ & $\%$ & $\mathrm{~N}$ & $\%$ & $\mathrm{~N}$ & $\%$ \\
\hline \multirow{6}{*}{ Public } & SA & 4 & $15.4 \%$ & 2 & $6.3 \%$ & 6 & $10.3 \%$ \\
\hline & A & 3 & $11.5 \%$ & 4 & $12.5 \%$ & 7 & $12.1 \%$ \\
\hline & NAND & 5 & $19.2 \%$ & 11 & $34.4 \%$ & 16 & $27.6 \%$ \\
\hline & DA & 13 & $50.0 \%$ & 14 & $43.8 \%$ & 27 & $46.6 \%$ \\
\hline & SD & 1 & $3.8 \%$ & 1 & $3.1 \%$ & 2 & $3.4 \%$ \\
\hline & Total & 26 & $100.0 \%$ & 32 & $100.0 \%$ & 58 & $100.0 \%$ \\
\hline \multirow{6}{*}{ Private } & SA & 4 & $15.4 \%$ & 1 & $3.1 \%$ & 5 & $8.6 \%$ \\
\hline & $\mathrm{A}$ & 7 & $26.9 \%$ & 9 & $28.1 \%$ & 16 & $27.6 \%$ \\
\hline & NAND & 4 & $15.4 \%$ & 10 & $31.3 \%$ & 14 & $24.1 \%$ \\
\hline & DA & 9 & $34.6 \%$ & 10 & $31.3 \%$ & 19 & $32.8 \%$ \\
\hline & SD & 2 & $7.7 \%$ & 2 & $6.3 \%$ & 4 & $6.9 \%$ \\
\hline & Total & 26 & $100.0 \%$ & 32 & $100.0 \%$ & 58 & $100.0 \%$ \\
\hline \multirow[t]{6}{*}{ Total } & SA & 8 & $15.4 \%$ & 3 & $4.7 \%$ & 11 & $9.5 \%$ \\
\hline & A & 10 & $19.2 \%$ & 13 & $20.3 \%$ & 23 & $19.8 \%$ \\
\hline & NAND & 9 & $17.3 \%$ & 21 & $32.8 \%$ & 30 & $25.9 \%$ \\
\hline & DA & 22 & $42.3 \%$ & 24 & $37.5 \%$ & 46 & $39.7 \%$ \\
\hline & SD & 3 & $5.8 \%$ & 3 & $4.7 \%$ & 6 & $5.2 \%$ \\
\hline & Total & 52 & $100.0 \%$ & 64 & $100.0 \%$ & 116 & $100.0 \%$ \\
\hline
\end{tabular}

Table 51 revealed that $22.4 \%$ of the public school participants strongly agree and agree that foreign language class moves so quickly and worry about getting left behind, $27.6 \%$ neither agree nor disagree and $50 \%$ disagree and strongly disagree respectively with the statement, whereas $36.2 \%$ of the private school participants agree and strongly disagree $24.1 \%$ neither agree nor disagree, and $39.7 \%$ disagree and strongly disagree with the same statement. Such results indicate that the majority of the participants in the public and private schools feel that the pace of the foreign language class is adequate for their English level and they don't worry about getting left behind. Whereas a good number of participants in both sectors are irresponsible, have moderate anxiety, no motivation, no confidence, and don't care about how the foreign language class moves.

Table52. Q25. Anxiety post test results

\begin{tabular}{|c|c|c|c|c|c|}
\hline \multirow[t]{3}{*}{ School } & Q25 & \multicolumn{2}{|l|}{ Group } & \multicolumn{2}{|c|}{ Total } \\
\hline & & Experimental & Control & & \\
\hline & & \begin{tabular}{l|l|}
$\mathrm{N}$ & $\%$ \\
\end{tabular} & \begin{tabular}{|l|l}
$\mathrm{N}$ & $\%$ \\
\end{tabular} & $\mathrm{~N}$ & $\%$ \\
\hline
\end{tabular}


Could Cll Approach be a Remedy for Tripoli Secondary Students Speaking Skills?

\begin{tabular}{|c|c|c|c|c|c|c|c|}
\hline \multirow[t]{6}{*}{ Public } & SA & 0 & & 3 & $13.0 \%$ & 3 & $6.1 \%$ \\
\hline & A & 2 & $7.7 \%$ & 13 & $56.5 \%$ & 15 & $30.6 \%$ \\
\hline & NAND & 1 & $3.8 \%$ & 3 & $13.0 \%$ & 4 & $8.2 \%$ \\
\hline & DA & 15 & $57.7 \%$ & 4 & $17.4 \%$ & 19 & $38.8 \%$ \\
\hline & SD & 8 & $30.8 \%$ & 0 & & 8 & $16.3 \%$ \\
\hline & Total & 26 & $100.0 \%$ & 23 & $100.0 \%$ & 49 & $100.0 \%$ \\
\hline \multirow[t]{6}{*}{ Private } & $\mathrm{SA}$ & 0 & & 2 & $8.3 \%$ & 2 & $3.9 \%$ \\
\hline & A & 0 & & 5 & $20.8 \%$ & 5 & $9.8 \%$ \\
\hline & NAND & 0 & & 7 & $29.2 \%$ & 7 & $13.7 \%$ \\
\hline & DA & 15 & $55.6 \%$ & 8 & $33.3 \%$ & 23 & $45.1 \%$ \\
\hline & SD & 12 & $44.4 \%$ & 2 & $8.3 \%$ & 14 & $27.5 \%$ \\
\hline & Total & 27 & $100.0 \%$ & 24 & $100.0 \%$ & 51 & $100.0 \%$ \\
\hline \multirow[t]{6}{*}{ Total } & $\mathrm{SA}$ & 0 & & 5 & $10.6 \%$ & 5 & $5.0 \%$ \\
\hline & A & 2 & $3.8 \%$ & 18 & $38.3 \%$ & 20 & $20.0 \%$ \\
\hline & NAND & 1 & $1.9 \%$ & 10 & $21.3 \%$ & 11 & $11.0 \%$ \\
\hline & DA & 30 & $56.6 \%$ & 12 & $25.5 \%$ & 42 & $42.0 \%$ \\
\hline & SD & 20 & $37.7 \%$ & 2 & $4.3 \%$ & 22 & $22.0 \%$ \\
\hline & Total & 53 & $100.0 \%$ & 47 & $100.0 \%$ & 100 & $100.0 \%$ \\
\hline
\end{tabular}

Table 52 of the anxiety posttest revealed that $7.7 \%$ of the participants in the public experimental group agree with that foreign language class moves so quickly and worry about getting left behind, $3.8 \%$ of the participants neither agree nor disagree with the statement, and $88.5 \%$ of the participants disagree and strongly disagree respectively, while in the control group, $69.5 \%$ of the participants agree and strongly agree, $13 \%$ of the participants neither agree nor disagree, and $17.4 \%$ disagree with the same statement. Whereas $0 \%$ of the participants in the private experimental group agree and strongly agree with the tested statement, $0 \%$ neither agree nor disagree, and $100 \%$ of the participants disagree with it, while in the control group, $29.1 \%$ of the participants agree and strongly agree, $29.2 \%$ neither agree nor disagree, and $41.6 \%$ disagree and strongly disagree with it. Such differences in the results between the control and experimental groups indicate that anxiety has decreased in the experimental groups after implementing the CLL approach and participants find the pace of the class very adequate to their level and almost all the participants have more responsibility, more motivation and self confidence towards the foreign language, and don't worry at all about getting left behind which also indicate that they trust their English language teacher.

Table53. Q26. Anxiety pre test

\begin{tabular}{|c|c|c|c|c|c|c|c|}
\hline \multirow[t]{3}{*}{ School } & \multirow[t]{3}{*}{ Q26.I } & \multicolumn{4}{|c|}{ Group } & \multicolumn{2}{|c|}{ Total } \\
\hline & & \multicolumn{2}{|c|}{ Experimental } & \multicolumn{2}{|c|}{ Control } & & \\
\hline & & $\mathrm{N}$ & $\%$ & $\mathrm{~N}$ & $\%$ & $\mathrm{~N}$ & $\%$ \\
\hline \multirow{6}{*}{ Public } & SA & 2 & $7.7 \%$ & 3 & $9.4 \%$ & 5 & $8.6 \%$ \\
\hline & A & 10 & $38.5 \%$ & 3 & $9.4 \%$ & 13 & $22.4 \%$ \\
\hline & NAND & 2 & $7.7 \%$ & 7 & $21.9 \%$ & 9 & $15.5 \%$ \\
\hline & DA & 9 & $34.6 \%$ & 14 & $43.8 \%$ & 23 & $39.7 \%$ \\
\hline & SD & 3 & $11.5 \%$ & 5 & $15.6 \%$ & 8 & $13.8 \%$ \\
\hline & Total & 26 & $100.0 \%$ & 32 & $100.0 \%$ & 58 & $100.0 \%$ \\
\hline \multirow[t]{6}{*}{ Private } & SA & 1 & $3.8 \%$ & 0 & & 1 & $1.7 \%$ \\
\hline & A & 2 & $7.7 \%$ & 5 & $15.6 \%$ & 7 & $12.1 \%$ \\
\hline & NAND & 7 & $26.9 \%$ & 4 & $12.5 \%$ & 11 & $19.0 \%$ \\
\hline & DA & 10 & $38.5 \%$ & 13 & $40.6 \%$ & 23 & $39.7 \%$ \\
\hline & SD & 6 & $23.1 \%$ & 10 & $31.3 \%$ & 16 & $27.6 \%$ \\
\hline & Total & 26 & $100.0 \%$ & 32 & $100.0 \%$ & 58 & $100.0 \%$ \\
\hline \multirow[t]{6}{*}{ Total } & SA & 3 & $5.8 \%$ & 3 & $4.7 \%$ & 6 & $5.2 \%$ \\
\hline & $\mathrm{A}$ & 12 & $23.1 \%$ & 8 & $12.5 \%$ & 20 & $17.2 \%$ \\
\hline & NAND & 9 & $17.3 \%$ & 11 & $17.2 \%$ & 20 & $17.2 \%$ \\
\hline & DA & 19 & $36.5 \%$ & 27 & $42.2 \%$ & 46 & $39.7 \%$ \\
\hline & SD & 9 & $17.3 \%$ & 15 & $23.4 \%$ & 24 & $20.7 \%$ \\
\hline & Total & 52 & $100.0 \%$ & 64 & $100.0 \%$ & 116 & $100.0 \%$ \\
\hline
\end{tabular}

Table 53 revealed that $31 \%$ of the public school participants strongly agree and agree that they feel more tense and nervous in their foreign language class than in their other classes, $15.5 \%$ neither agree nor disagree, and $53.5 \%$ disagree and strongly disagree respectively with the statement, whereas $13.8 \%$ of the private school participants agree and strongly disagree, $19 \%$ neither agree nor disagree, and $67.3 \%$ disagree and strongly disagree with the same statement. Such results indicate that the majority of the participants in the public and private schools have the same anxiety level in all classes 
even in their foreign language class. And that a good number of the participants are irresponsible towards the foreign language class and it doesn't affect them since they don't care.

Table54. Q26. Anxiety post test results

\begin{tabular}{|c|c|c|c|c|c|c|c|}
\hline \multirow[t]{3}{*}{ School } & Q26.I & \multicolumn{4}{|c|}{ Group } & \multicolumn{2}{|c|}{ Total } \\
\hline & & \multicolumn{2}{|c|}{ Experimental } & \multicolumn{2}{|c|}{ Control } & & \\
\hline & & $\mathrm{N}$ & $\%$ & $\mathrm{~N}$ & $\%$ & $\mathrm{~N}$ & $\%$ \\
\hline \multirow[t]{6}{*}{ Public } & SA & & & & & & \\
\hline & A & 1 & $3.8 \%$ & 9 & $39.1 \%$ & 10 & $20.4 \%$ \\
\hline & NAND & 1 & $3.8 \%$ & 12 & $52.2 \%$ & 13 & $26.5 \%$ \\
\hline & DA & 13 & $50.0 \%$ & 2 & $8.7 \%$ & 15 & $30.6 \%$ \\
\hline & SD & 11 & $42.3 \%$ & 0 & & 11 & $22.4 \%$ \\
\hline & Total & 26 & $100.0 \%$ & 23 & $100.0 \%$ & 49 & $100.0 \%$ \\
\hline \multirow[t]{6}{*}{ Private } & SA & 0 & & 1 & $4.2 \%$ & 1 & $2.0 \%$ \\
\hline & A & 0 & & 1 & $4.2 \%$ & 1 & $2.0 \%$ \\
\hline & NAND & 0 & & 6 & $25.0 \%$ & 6 & $11.8 \%$ \\
\hline & DA & 5 & $18.5 \%$ & 9 & $37.5 \%$ & 14 & $27.5 \%$ \\
\hline & SD & 22 & $81.5 \%$ & 7 & $29.2 \%$ & 29 & $56.9 \%$ \\
\hline & Total & 27 & $100.0 \%$ & 24 & $100.0 \%$ & 51 & $100.0 \%$ \\
\hline \multirow{6}{*}{ Total } & SA & 0 & & 1 & $2.1 \%$ & 1 & $1.0 \%$ \\
\hline & $\mathrm{A}$ & 1 & $1.9 \%$ & 10 & $21.3 \%$ & 11 & $11.0 \%$ \\
\hline & NAND & 1 & $1.9 \%$ & 18 & $38.3 \%$ & 19 & $19.0 \%$ \\
\hline & DA & 18 & $34.0 \%$ & 11 & $23.4 \%$ & 29 & $29.0 \%$ \\
\hline & SD & 33 & $62.3 \%$ & 7 & $14.9 \%$ & 40 & $40.0 \%$ \\
\hline & Total & 53 & $100.0 \%$ & 47 & $100.0 \%$ & 100 & $100.0 \%$ \\
\hline
\end{tabular}

Table 54 results of the anxiety posttest indicated that $3.8 \%$ of the participants in the experimental group of the public school agree with that they feel more tense and nervous in their foreign language class than in their other classes, $3.8 \%$ of the participants neither agree nor disagree with the statement, and $92.3 \%$ of the participants disagree and strongly disagree respectively with it, while in the control group, $39.1 \%$ of the participants agree and strongly agree, $52.2 \%$ of the participants neither agree nor disagree, and $8.7 \%$ disagree with the same statement.

Whereas $0 \%$ of the participants in the experimental group of the private school agree and strongly agree with the tested statement, $0 \%$ neither agree nor disagree, and $100 \%$ of the participants disagree, while in the control group, $8.4 \%$ of the participants agree, $25 \%$ neither agree nor disagree, and $66.7 \%$ disagree with the same statement. Such differences in the results between the control and experimental groups indicate that anxiety has dramatically decreased in the experimental groups and almost all the participants have more responsibility, motivation and self confidence towards the foreign language after implementing the CLL approach. Noting that, the results indicated that the majority of the participants in the control group of the private school have low anxiety and high confidence at the end of the year.

Table55. Q27. Anxiety pre test

\begin{tabular}{|c|c|c|c|c|c|c|c|}
\hline \multirow[t]{3}{*}{ School } & \multirow[t]{3}{*}{ Q27. } & \multicolumn{4}{|c|}{ Group } & \multicolumn{2}{|c|}{ Total } \\
\hline & & \multicolumn{2}{|c|}{ Experimental } & \multicolumn{2}{|c|}{ Control } & \multirow{2}{*}{$\mathrm{N}$} & \multirow[b]{2}{*}{$\%$} \\
\hline & & $\mathrm{N}$ & $\%$ & $\mathrm{~N}$ & $\%$ & & \\
\hline \multirow[t]{6}{*}{ Public } & SA & 2 & $7.7 \%$ & 0 & & 2 & $3.4 \%$ \\
\hline & $\mathrm{A}$ & 5 & $19.2 \%$ & 6 & $18.8 \%$ & 11 & $19.0 \%$ \\
\hline & NAND & 5 & $19.2 \%$ & 13 & $40.6 \%$ & 18 & $31.0 \%$ \\
\hline & $\mathrm{DA}$ & 13 & $50.0 \%$ & 7 & $21.9 \%$ & 20 & $34.5 \%$ \\
\hline & SD & 1 & $3.8 \%$ & 6 & $18.8 \%$ & 7 & $12.1 \%$ \\
\hline & Total & 26 & $100.0 \%$ & 32 & $100.0 \%$ & 58 & $100.0 \%$ \\
\hline \multirow[t]{6}{*}{ Private } & SA & 3 & $12.0 \%$ & 3 & $9.7 \%$ & 6 & $10.7 \%$ \\
\hline & $\mathrm{A}$ & 4 & $16.0 \%$ & 4 & $12.9 \%$ & 8 & $14.3 \%$ \\
\hline & NAND & 5 & $20.0 \%$ & 3 & $9.7 \%$ & 8 & $14.3 \%$ \\
\hline & DA & 9 & $36.0 \%$ & 8 & $25.8 \%$ & 17 & $30.4 \%$ \\
\hline & SD & 4 & $16.0 \%$ & 13 & $41.9 \%$ & 17 & $30.4 \%$ \\
\hline & Total & 25 & $100.0 \%$ & 31 & $100.0 \%$ & 56 & $100.0 \%$ \\
\hline \multirow[t]{6}{*}{ Total } & SA & 5 & $9.8 \%$ & 3 & $4.8 \%$ & 8 & $7.0 \%$ \\
\hline & $\mathrm{A}$ & 9 & $17.6 \%$ & 10 & $15.9 \%$ & 19 & $16.7 \%$ \\
\hline & NAND & 10 & $19.6 \%$ & 16 & $25.4 \%$ & 26 & $22.8 \%$ \\
\hline & DA & 22 & $43.1 \%$ & 15 & $23.8 \%$ & 37 & $32.5 \%$ \\
\hline & SD & 5 & $9.8 \%$ & 19 & $30.2 \%$ & 24 & $21.1 \%$ \\
\hline & Total & 51 & $100.0 \%$ & 63 & $100.0 \%$ & 114 & $100.0 \%$ \\
\hline
\end{tabular}


Table 55 results revealed that $22.4 \%$ of the public school participants strongly agree and agree that they get nervous and confused when they are speaking in their foreign language class, $31 \%$ neither agree nor disagree with it, and $46.6 \%$ disagree and strongly disagree respectively, whereas $25 \%$ of the private school participants agree and strongly disagree, $14.3 \%$ neither agree nor disagree, and $60.8 \%$ disagree and strongly disagree with the statement. Such results indicate that the majority of the participants in the public and private schools have moderate anxiety level and a good number of the participants have high anxiety with low motivation and confidence in their foreign language.

Table56. Q27. Anxiety post test results

\begin{tabular}{|c|c|c|c|c|c|c|c|}
\hline \multirow[t]{3}{*}{ School } & \multirow[t]{3}{*}{ Q27.I } & \multicolumn{4}{|c|}{ Group } & \multicolumn{2}{|c|}{ Total } \\
\hline & & \multicolumn{2}{|c|}{ Experimental } & \multicolumn{2}{|c|}{ Control } & & \\
\hline & & $\mathrm{N}$ & $\%$ & $\mathrm{~N}$ & $\%$ & $\mathrm{~N}$ & $\%$ \\
\hline \multirow[t]{6}{*}{ Public } & SA & 0 & & 10 & $43.5 \%$ & 10 & $20.4 \%$ \\
\hline & A & 1 & $3.8 \%$ & 13 & $56.5 \%$ & 14 & $28.6 \%$ \\
\hline & NAND & & & & & & \\
\hline & DA & 14 & $53.8 \%$ & 0 & & 14 & $28.6 \%$ \\
\hline & SD & 11 & $42.3 \%$ & 0 & & 11 & $22.4 \%$ \\
\hline & Total & 26 & $100.0 \%$ & 23 & $100.0 \%$ & 49 & $100.0 \%$ \\
\hline \multirow[t]{6}{*}{ Private } & $\mathrm{SA}$ & 0 & & 1 & $4.2 \%$ & 1 & $2.0 \%$ \\
\hline & A & 0 & & 5 & $20.8 \%$ & 5 & $9.8 \%$ \\
\hline & NAND & 0 & & 4 & $16.7 \%$ & 4 & $7.8 \%$ \\
\hline & DA & 16 & $59.3 \%$ & 11 & $45.8 \%$ & 27 & $52.9 \%$ \\
\hline & SD & 11 & $40.7 \%$ & 3 & $12.5 \%$ & 14 & $27.5 \%$ \\
\hline & Total & 27 & $100.0 \%$ & 24 & $100.0 \%$ & 51 & $100.0 \%$ \\
\hline \multirow[t]{6}{*}{ Total } & SA & 0 & & 11 & $23.4 \%$ & 11 & $11.0 \%$ \\
\hline & A & 1 & $1.9 \%$ & 18 & $38.3 \%$ & 19 & $19.0 \%$ \\
\hline & NAND & 0 & & 4 & $8.5 \%$ & 4 & $4.0 \%$ \\
\hline & DA & 30 & $56.6 \%$ & 11 & $23.4 \%$ & 41 & $41.0 \%$ \\
\hline & SD & 22 & $41.5 \%$ & 3 & $6.4 \%$ & 25 & $25.0 \%$ \\
\hline & Total & 53 & $100.0 \%$ & 47 & $100.0 \%$ & 100 & $100.0 \%$ \\
\hline
\end{tabular}

Table 56 results of the anxiety posttest revealed that $0 \%$ of the participants in the public experimental group agree with that they get nervous and confused when they are speaking in their foreign language class, $0 \%$ of the participants neither agree nor disagree with the statement, and $100 \%$ of the participants disagree and strongly disagree respectively, while in the control group, $87 \%$ of the participants agree and strongly agree, $13 \%$ of the participants neither agree nor disagree, and $0 \%$ disagree with the same tested statement. Whereas $0 \%$ of the participants in the private experimental group agree and strongly agree with the tested statement, $0 \%$ neither agree nor disagree and $100 \%$ of the participants disagree, while in the control group, $25 \%$ of the participants agree, $16.7 \%$ neither agree nor disagree, and $58.3 \%$ disagree with the same statement. Such differences in the results between the control and experimental groups indicate that anxiety has dramatically decreased in the experimental groups and almost all the participants have more responsibility, more motivation and self confidence towards speaking the foreign language. Moreover, it is noticed that the participants of the private control group are responsible, motivated with moderate to low anxiety level at the end of the year.

Table57. Q28. Anxiety pre test

\begin{tabular}{|c|c|c|c|c|c|c|c|}
\hline \multirow[t]{3}{*}{ School } & \multirow[t]{3}{*}{ Q28. } & \multicolumn{4}{|c|}{ Group } & \multicolumn{2}{|c|}{ Total } \\
\hline & & \multicolumn{2}{|c|}{ Experimental } & \multicolumn{2}{|c|}{ Control } & & \\
\hline & & $\mathrm{N}$ & $\%$ & $\mathrm{~N}$ & $\%$ & $\mathrm{~N}$ & $\%$ \\
\hline \multirow[t]{6}{*}{ Public } & SA & 4 & $15.4 \%$ & 7 & $21.9 \%$ & 11 & $19.0 \%$ \\
\hline & $\mathrm{A}$ & 8 & $30.8 \%$ & 7 & $21.9 \%$ & 15 & $25.9 \%$ \\
\hline & NAND & 6 & $23.1 \%$ & 11 & $34.4 \%$ & 17 & $29.3 \%$ \\
\hline & DA & 6 & $23.1 \%$ & 4 & $12.5 \%$ & 10 & $17.2 \%$ \\
\hline & SD & 2 & $7.7 \%$ & 3 & $9.4 \%$ & 5 & $8.6 \%$ \\
\hline & Total & 26 & $100.0 \%$ & 32 & $100.0 \%$ & 58 & $100.0 \%$ \\
\hline \multirow[t]{6}{*}{ Private } & $\mathrm{SA}$ & 6 & $23.1 \%$ & 14 & $43.8 \%$ & 20 & $34.5 \%$ \\
\hline & A & 4 & $15.4 \%$ & 7 & $21.9 \%$ & 11 & $19.0 \%$ \\
\hline & NAND & 4 & $15.4 \%$ & 9 & $28.1 \%$ & 13 & $22.4 \%$ \\
\hline & DA & 7 & $26.9 \%$ & 2 & $6.3 \%$ & 9 & $15.5 \%$ \\
\hline & SD & 5 & $19.2 \%$ & 0 & & 5 & $8.6 \%$ \\
\hline & Total & 26 & $100.0 \%$ & 32 & $100.0 \%$ & 58 & $100.0 \%$ \\
\hline
\end{tabular}


Could Cll Approach be a Remedy for Tripoli Secondary Students Speaking Skills?

\begin{tabular}{|l|l|l|l|l|l|l|l|}
\hline \multirow{3}{*}{ Total } & SA & 10 & $19.2 \%$ & 21 & $32.8 \%$ & 31 & $26.7 \%$ \\
\cline { 2 - 9 } & A & 12 & $23.1 \%$ & 14 & $21.9 \%$ & 26 & $22.4 \%$ \\
\cline { 2 - 8 } & NAND & 10 & $19.2 \%$ & 20 & $31.3 \%$ & 30 & $25.9 \%$ \\
\cline { 2 - 8 } & DA & 13 & $25.0 \%$ & 6 & $9.4 \%$ & 19 & $16.4 \%$ \\
\cline { 2 - 8 } & SD & 7 & $13.5 \%$ & 3 & $4.7 \%$ & 10 & $8.6 \%$ \\
\cline { 2 - 8 } & Total & 52 & $100.0 \%$ & 64 & $100.0 \%$ & 116 & $100.0 \%$ \\
\hline
\end{tabular}

Table 57 results revealed that $44.9 \%$ of the public school participants strongly agree and agree that when they are on their way to foreign language class, they feel very sure and relaxed,29.3\% neither agree nor disagree, and $25.8 \%$ disagree and strongly disagree respectively with the statement. Whereas $53.5 \%$ of the private school participants agree and strongly disagree, $22.4 \%$ neither agree nor disagree, and $24.1 \%$ disagree and strongly disagree with it. Such results indicate that the majority of the participants in the public and private schools have moderate anxiety and a good number of the participants have no motivation and no confidence towards the foreign language class which makes them indifferent and irresponsible towards it.

Table58. Q28. Anxiety post test results

\begin{tabular}{|c|c|c|c|c|c|c|c|}
\hline \multirow[t]{3}{*}{ School } & \multirow[t]{3}{*}{ Q28. } & \multicolumn{4}{|c|}{ Group } & \multicolumn{2}{|c|}{ Total } \\
\hline & & \multicolumn{2}{|c|}{ Experimental } & \multicolumn{2}{|c|}{ Control } & & \\
\hline & & $\mathrm{N}$ & $\%$ & $\mathrm{~N}$ & $\%$ & $\mathrm{~N}$ & $\%$ \\
\hline \multirow{6}{*}{ Public } & $\mathrm{SA}$ & 13 & $50.0 \%$ & 0 & & 13 & $26.5 \%$ \\
\hline & $\mathrm{A}$ & 11 & $42.3 \%$ & 1 & $4.3 \%$ & 12 & $24.5 \%$ \\
\hline & NAND & 2 & $7.7 \%$ & 3 & $13.0 \%$ & 5 & $10.2 \%$ \\
\hline & DA & 0 & & 13 & $56.5 \%$ & 13 & $26.5 \%$ \\
\hline & SD & 0 & & 6 & $26.1 \%$ & 6 & $12.2 \%$ \\
\hline & Total & 26 & $100.0 \%$ & 23 & $100.0 \%$ & 49 & $100.0 \%$ \\
\hline \multirow[t]{6}{*}{ Private } & SA & 8 & $29.6 \%$ & 1 & $4.2 \%$ & 9 & $17.6 \%$ \\
\hline & $\mathrm{A}$ & 16 & $59.3 \%$ & 8 & $33.3 \%$ & 24 & $47.1 \%$ \\
\hline & NAND & 3 & $11.1 \%$ & 5 & $20.8 \%$ & 8 & $15.7 \%$ \\
\hline & DA & 0 & & 7 & $29.2 \%$ & 7 & $13.7 \%$ \\
\hline & SD & 0 & & 3 & $12.5 \%$ & 3 & $5.9 \%$ \\
\hline & Total & 27 & $100.0 \%$ & 24 & $100.0 \%$ & 51 & $100.0 \%$ \\
\hline \multirow{6}{*}{ Total } & SA & 21 & $39.6 \%$ & 1 & $2.1 \%$ & 22 & $22.0 \%$ \\
\hline & $\mathrm{A}$ & 27 & $50.9 \%$ & 9 & $19.1 \%$ & 36 & $36.0 \%$ \\
\hline & NAND & 5 & $9.4 \%$ & 8 & $17.0 \%$ & 13 & $13.0 \%$ \\
\hline & DA & 0 & & 20 & $42.6 \%$ & 20 & $20.0 \%$ \\
\hline & SD & 0 & & 9 & $19.1 \%$ & 9 & $9.0 \%$ \\
\hline & Total & 53 & $100.0 \%$ & 47 & $100.0 \%$ & 100 & $100.0 \%$ \\
\hline
\end{tabular}

Table 58 results of the anxiety posttest revealed that $92.3 \%$ of the participants in the public experimental group strongly agree and agree with that when they are on their way to foreign language class, they feel very sure and relaxed, $7.7 \%$ of the participants neither agree nor disagree, and $0 \%$ of the participants disagree and strongly disagree respectively with it, while in the control group, $4.3 \%$ of the participants agree, $13 \%$ of the participants neither agree nor disagree and $82.6 \%$ disagree with the same statement.

Whereas $88.9 \%$ of the participants in the experimental group of the private school agree and strongly agree with the tested statement, $11.1 \%$ neither agree nor disagree, and $0 \%$ of the participants disagree with it, while in the control group, 37.5\% of the participants agree with,20.8\% neither agree nor disagree, and $41.7 \%$ disagree with the same statement. Such differences in the results between the control and experimental groups indicate that anxiety has dramatically decreased in the experimental groups and almost all the participants have more responsibility, more motivation and self confidence towards their foreign language class.

Table59. Q29. Anxiety pre test

\begin{tabular}{|c|c|c|c|c|c|c|c|}
\hline \multirow[t]{3}{*}{ School } & \multirow[t]{3}{*}{ Q29. } & \multicolumn{4}{|c|}{ Group } & \multirow{3}{*}{$\begin{array}{l}\text { Total } \\
\mathrm{N}\end{array}$} & \multirow[b]{3}{*}{$\%$} \\
\hline & & \multicolumn{2}{|c|}{ Experimental } & \multicolumn{2}{|c|}{ Control } & & \\
\hline & & $\mathrm{N}$ & $\%$ & $\mathrm{~N}$ & $\%$ & & \\
\hline \multirow[t]{5}{*}{ Public } & SA & 7 & $26.9 \%$ & 3 & $9.4 \%$ & 10 & $17.2 \%$ \\
\hline & $\mathrm{A}$ & 9 & $34.6 \%$ & 8 & $25.0 \%$ & 17 & $29.3 \%$ \\
\hline & NAND & 0 & & 7 & $21.9 \%$ & 7 & $12.1 \%$ \\
\hline & DA & 8 & $30.8 \%$ & 12 & $37.5 \%$ & 20 & $34.5 \%$ \\
\hline & SD & 2 & $7.7 \%$ & 2 & $6.3 \%$ & 4 & $6.9 \%$ \\
\hline
\end{tabular}


Could Cll Approach be a Remedy for Tripoli Secondary Students Speaking Skills?

\begin{tabular}{|c|c|c|c|c|c|c|c|}
\hline & Total & 26 & $100.0 \%$ & 32 & $100.0 \%$ & 58 & $100.0 \%$ \\
\hline \multirow[t]{6}{*}{ Private } & SA & 2 & $7.7 \%$ & 7 & $21.9 \%$ & 9 & $15.5 \%$ \\
\hline & $\mathrm{A}$ & 10 & $38.5 \%$ & 9 & $28.1 \%$ & 19 & $32.8 \%$ \\
\hline & NAND & 6 & $23.1 \%$ & 7 & $21.9 \%$ & 13 & $22.4 \%$ \\
\hline & DA & 3 & $11.5 \%$ & 4 & $12.5 \%$ & 7 & $12.1 \%$ \\
\hline & SD & 5 & $19.2 \%$ & 5 & $15.6 \%$ & 10 & $17.2 \%$ \\
\hline & Total & 26 & $100.0 \%$ & 32 & $100.0 \%$ & 58 & $100.0 \%$ \\
\hline \multirow[t]{6}{*}{ Total } & SA & 9 & $17.3 \%$ & 10 & $15.6 \%$ & 19 & $16.4 \%$ \\
\hline & A & 19 & $36.5 \%$ & 17 & $26.6 \%$ & 36 & $31.0 \%$ \\
\hline & NAND & 6 & $11.5 \%$ & 14 & $21.9 \%$ & 20 & $17.2 \%$ \\
\hline & DA & 11 & $21.2 \%$ & 16 & $25.0 \%$ & 27 & $23.3 \%$ \\
\hline & SD & 7 & $13.5 \%$ & 7 & $10.9 \%$ & 14 & $12.1 \%$ \\
\hline & Total & 52 & $100.0 \%$ & 64 & $100.0 \%$ & 116 & $100.0 \%$ \\
\hline
\end{tabular}

Table 59 revealed that $46.5 \%$ of the public school participants strongly agree and agree that they get nervous when they don't understand every word the foreign language teacher says, $12.1 \%$ neither agree nor disagree, and $41.4 \%$ disagree and strongly disagree respectively with the statement, whereas $48.3 \%$ of the private school participants agree and strongly disagree, $22.4 \%$ neither agree nor disagree and $29.3 \%$ disagree and strongly disagree with the same statement. Such results indicate that the majority of the participants in the public and private schools have moderate anxiety and that they want to understand every word the foreign language teacher says.

Table60. Q29. Anxiety post test results

\begin{tabular}{|c|c|c|c|c|c|c|c|}
\hline \multirow[t]{3}{*}{ School } & \multirow[t]{3}{*}{ Q29. } & \multicolumn{4}{|c|}{ Group } & \multirow{3}{*}{$\begin{array}{l}\text { Total } \\
\mathrm{N}\end{array}$} & \multirow[b]{3}{*}{$\%$} \\
\hline & & \multicolumn{2}{|c|}{ Experimental } & \multicolumn{2}{|c|}{ Control } & & \\
\hline & & $\mathrm{N}$ & $\%$ & $\mathrm{~N}$ & $\%$ & & \\
\hline \multirow[t]{6}{*}{ Public } & SA & 1 & $3.8 \%$ & 7 & $30.4 \%$ & 8 & $16.3 \%$ \\
\hline & $\mathrm{A}$ & 3 & $11.5 \%$ & 15 & $65.2 \%$ & 18 & $36.7 \%$ \\
\hline & NAND & 7 & $26.9 \%$ & 1 & $4.3 \%$ & 8 & $16.3 \%$ \\
\hline & DA & 15 & $57.7 \%$ & 0 & & 15 & $30.6 \%$ \\
\hline & SD & & & & & & \\
\hline & Total & 26 & $100.0 \%$ & 23 & $100.0 \%$ & 49 & $100.0 \%$ \\
\hline \multirow[t]{6}{*}{ Private } & SA & 0 & & 4 & $16.7 \%$ & 4 & $7.8 \%$ \\
\hline & $\mathrm{A}$ & 1 & $3.7 \%$ & 8 & $33.3 \%$ & 9 & $17.6 \%$ \\
\hline & NAND & 9 & $33.3 \%$ & 5 & $20.8 \%$ & 14 & $27.5 \%$ \\
\hline & DA & 16 & $59.3 \%$ & 4 & $16.7 \%$ & 20 & $39.2 \%$ \\
\hline & SD & 1 & $3.7 \%$ & 3 & $12.5 \%$ & 4 & $7.8 \%$ \\
\hline & Total & 27 & $100.0 \%$ & 24 & $100.0 \%$ & 51 & $100.0 \%$ \\
\hline \multirow[t]{6}{*}{ Total } & SA & 1 & $1.9 \%$ & 11 & $23.4 \%$ & 12 & $12.0 \%$ \\
\hline & A & 4 & $7.5 \%$ & 23 & $48.9 \%$ & 27 & $27.0 \%$ \\
\hline & NAND & 16 & $30.2 \%$ & 6 & $12.8 \%$ & 22 & $22.0 \%$ \\
\hline & DA & 31 & $58.5 \%$ & 4 & $8.5 \%$ & 35 & $35.0 \%$ \\
\hline & SD & 1 & $1.9 \%$ & 3 & $6.4 \%$ & 4 & $4.0 \%$ \\
\hline & Total & 53 & $100.0 \%$ & 47 & $100.0 \%$ & 100 & $100.0 \%$ \\
\hline
\end{tabular}

Table 60 results of the anxiety posttest showed that $15.3 \%$ of the participants in the public experimental group strongly agree and agree with that they get nervous when they don't understand every word the foreign language teacher says, $26.9 \%$ of the participants neither agree nor disagree and $57.7 \%$ of the participants disagree, while in the control group, $95.6 \%$ of the participants agree and strongly agree, $4.3 \%$ of the participants neither agree nor disagree, and $0 \%$ disagree with the same statement. Whereas $3.7 \%$ of the participants in the private experimental group agree with the tested statement, $33.3 \%$ neither agree nor disagree with the statement, and $63 \%$ of the participants disagree, while in the control group, $50 \%$ of the participants agree, $20.8 \%$ neither agree nor disagree, $29.2 \%$ disagree with it. Such differences in the results between the control and experimental groups indicate that anxiety has dramatically decreased in the experimental groups and almost all the participants have more self confidence towards the foreign language after the conduction of CLL approach. 
Table61. Q30. Anxiety pre test

\begin{tabular}{|c|c|c|c|c|c|c|c|}
\hline \multirow[t]{3}{*}{ School } & \multirow[t]{3}{*}{ Q30. } & \multicolumn{4}{|c|}{ Group } & \multirow{3}{*}{$\begin{array}{l}\text { Total } \\
\mathrm{N}\end{array}$} & \multirow[b]{3}{*}{$\%$} \\
\hline & & \multicolumn{2}{|c|}{ Experimental } & \multicolumn{2}{|c|}{ Control } & & \\
\hline & & $\mathrm{N}$ & $\%$ & $\mathrm{~N}$ & $\%$ & & \\
\hline \multirow{6}{*}{ Public } & SA & 1 & $3.8 \%$ & 6 & $18.8 \%$ & 7 & $12.1 \%$ \\
\hline & A & 11 & $42.3 \%$ & 9 & $28.1 \%$ & 20 & $34.5 \%$ \\
\hline & NAND & 8 & $30.8 \%$ & 10 & $31.3 \%$ & 18 & $31.0 \%$ \\
\hline & DA & 6 & $23.1 \%$ & 6 & $18.8 \%$ & 12 & $20.7 \%$ \\
\hline & SD & 0 & & 1 & $3.1 \%$ & 1 & $1.7 \%$ \\
\hline & Total & 26 & $100.0 \%$ & 32 & $100.0 \%$ & 58 & $100.0 \%$ \\
\hline \multirow[t]{6}{*}{ Private } & SA & 8 & $30.8 \%$ & 3 & $9.7 \%$ & 11 & $19.3 \%$ \\
\hline & A & 8 & $30.8 \%$ & 6 & $19.4 \%$ & 14 & $24.6 \%$ \\
\hline & NAND & 3 & $11.5 \%$ & 9 & $29.0 \%$ & 12 & $21.1 \%$ \\
\hline & DA & 6 & $23.1 \%$ & 13 & $41.9 \%$ & 19 & $33.3 \%$ \\
\hline & SD & 1 & $3.8 \%$ & 0 & & 1 & $1.8 \%$ \\
\hline & Total & 26 & $100.0 \%$ & 31 & $100.0 \%$ & 57 & $100.0 \%$ \\
\hline \multirow[t]{6}{*}{ Total } & SA & 9 & $17.3 \%$ & 9 & $14.3 \%$ & 18 & $15.7 \%$ \\
\hline & A & 19 & $36.5 \%$ & 15 & $23.8 \%$ & 34 & $29.6 \%$ \\
\hline & NAND & 11 & $21.2 \%$ & 19 & $30.2 \%$ & 30 & $26.1 \%$ \\
\hline & DA & 12 & $23.1 \%$ & 19 & $30.2 \%$ & 31 & $27.0 \%$ \\
\hline & SD & 1 & $1.9 \%$ & 1 & $1.6 \%$ & 2 & $1.7 \%$ \\
\hline & Total & 52 & $100.0 \%$ & 63 & $100.0 \%$ & 115 & $100.0 \%$ \\
\hline
\end{tabular}

Table 61 revealed that $46.6 \%$ of the public school participants strongly agree and agree that they feel overwhelmed by the number of rules they have to learn to speak a foreign language, $31 \%$ neither agree nor disagree, and $22.4 \%$ disagree and strongly disagree respectively with it, whereas $43.9 \%$ of the private school participants agree and strongly disagree, $21.1 \%$ neither agree nor disagree, and $35.1 \%$ disagree and strongly disagree with the same statement. Such results indicate that the majority of the participants in the public and private schools have moderate to high anxiety and low confidence because of the number of the rules they have to learn to speak foreign language.

Table62. Q30. Anxiety post test results

\begin{tabular}{|c|c|c|c|c|c|c|c|}
\hline & Q30 & \multicolumn{4}{|c|}{ Group } & \multirow[t]{2}{*}{ Total } & \\
\hline & & \multicolumn{2}{|c|}{ Experimental } & \multicolumn{2}{|r|}{ Control } & & \\
\hline & & $\mathrm{N}$ & $\%$ & $\mathrm{~N}$ & $\%$ & $\mathrm{~N}$ & $\%$ \\
\hline \multirow[t]{6}{*}{ Public } & SA & 0 & & 6 & $26.1 \%$ & 6 & $12.2 \%$ \\
\hline & A & 5 & $19.2 \%$ & 11 & $47.8 \%$ & 16 & $32.7 \%$ \\
\hline & NAND & 8 & $30.8 \%$ & 6 & $26.1 \%$ & 14 & $28.6 \%$ \\
\hline & DA & 13 & $50.0 \%$ & 0 & & 13 & $26.5 \%$ \\
\hline & SD & & & & & & \\
\hline & Total & 26 & $100.0 \%$ & 23 & $100.0 \%$ & 49 & $100.0 \%$ \\
\hline \multirow[t]{6}{*}{ Private } & SA & 0 & & 4 & $16.7 \%$ & 4 & $7.8 \%$ \\
\hline & A & 6 & $22.2 \%$ & 7 & $29.2 \%$ & 13 & $25.5 \%$ \\
\hline & NAND & 13 & $48.1 \%$ & 7 & $29.2 \%$ & 20 & $39.2 \%$ \\
\hline & DA & 7 & $25.9 \%$ & 6 & $25.0 \%$ & 13 & $25.5 \%$ \\
\hline & SD & 1 & $3.7 \%$ & 0 & & 1 & $2.0 \%$ \\
\hline & Total & 27 & $100.0 \%$ & 24 & $100.0 \%$ & 51 & $100.0 \%$ \\
\hline \multirow[t]{6}{*}{ Total } & SA & 0 & & 10 & $21.3 \%$ & 10 & $10.0 \%$ \\
\hline & $\mathrm{A}$ & 11 & $20.8 \%$ & 18 & $38.3 \%$ & 29 & $29.0 \%$ \\
\hline & NAND & 21 & $39.6 \%$ & 13 & $27.7 \%$ & 34 & $34.0 \%$ \\
\hline & DA & 20 & $37.7 \%$ & 6 & $12.8 \%$ & 26 & $26.0 \%$ \\
\hline & SD & 1 & $1.9 \%$ & 0 & & 1 & $1.0 \%$ \\
\hline & Total & 53 & $100.0 \%$ & 47 & $100.0 \%$ & 100 & $100.0 \%$ \\
\hline
\end{tabular}

Table 62 results of the anxiety posttest pointed that $19.2 \%$ of the participants in the public experimental group agree with that they feel overwhelmed by the number of rules they have to learn to speak a foreign language, $30.8 \%$ of the participants neither agree nor disagree and $50 \%$ of the participants disagree and strongly disagree respectively, while in the control group, $73.9 \%$ of the participants agree and strongly agree, $26.1 \%$ of the participants neither agree nor disagree, and $0 \%$ disagree with the same statement. 
Whereas $22.2 \%$ of the participants in the private experimental group agree with the tested statement, $48.1 \%$ neither agree nor disagree and $29.6 \%$ of the participants disagree with it, while in the control group, $45.9 \%$ of the participants agree, $29.2 \%$ neither agree nor disagree, and $25 \%$ disagree with the same statement. Such differences in the results between the control and experimental groups indicate that anxiety has dramatically decreased in the experimental groups and almost all the participants have more responsibility, motivation and self confidence towards learning foreign language. Moreover, it is noticed that a considerable number of the participants in the private experimental group is still irresponsible towards the foreign language and learning its rules.

Table63. Q31. Anxiety pre test

\begin{tabular}{|c|c|c|c|c|c|c|c|}
\hline \multirow[t]{3}{*}{ School } & \multirow[t]{3}{*}{ Q31. } & \multicolumn{4}{|c|}{ Group } & \multirow{3}{*}{$\begin{array}{l}\text { Total } \\
\mathrm{N}\end{array}$} & \multirow[b]{3}{*}{$\%$} \\
\hline & & \multicolumn{2}{|c|}{ Experimental } & \multicolumn{2}{|c|}{ Control } & & \\
\hline & & $\mathrm{N}$ & $\%$ & $\mathrm{~N}$ & $\%$ & & \\
\hline \multirow[t]{6}{*}{ Public } & SA & 9 & $34.6 \%$ & 4 & $12.5 \%$ & 13 & $22.4 \%$ \\
\hline & A & 6 & $23.1 \%$ & 7 & $21.9 \%$ & 13 & $22.4 \%$ \\
\hline & NAND & 4 & $15.4 \%$ & 3 & $9.4 \%$ & 7 & $12.1 \%$ \\
\hline & DA & 3 & $11.5 \%$ & 8 & $25.0 \%$ & 11 & $19 \%$ \\
\hline & SD & 4 & $15.4 \%$ & 10 & $31.3 \%$ & 14 & $24.1 \%$ \\
\hline & Total & 26 & $100.0 \%$ & 32 & $100.0 \%$ & 58 & $100.0 \%$ \\
\hline \multirow[t]{6}{*}{ Private } & SA & 3 & $11.5 \%$ & 3 & $9.7 \%$ & 6 & $10.5 \%$ \\
\hline & A & 12 & $46.2 \%$ & 12 & $38.7 \%$ & 24 & $42.1 \%$ \\
\hline & NAND & 3 & $11.5 \%$ & 6 & $19.4 \%$ & 9 & $15.8 \%$ \\
\hline & DA & 5 & $19.2 \%$ & 5 & $16.1 \%$ & 10 & $17.5 \%$ \\
\hline & SD & 3 & $11.5 \%$ & 5 & $16.1 \%$ & 8 & $14.0 \%$ \\
\hline & Total & 26 & $100.0 \%$ & 31 & $100.0 \%$ & 57 & $100.0 \%$ \\
\hline \multirow[t]{6}{*}{ Total } & SA & 7 & $13.5 \%$ & 7 & $11.1 \%$ & 14 & $12.2 \%$ \\
\hline & A & 18 & $34.6 \%$ & 19 & $30.2 \%$ & 37 & $32.2 \%$ \\
\hline & NAND & 6 & $11.5 \%$ & 9 & $14.3 \%$ & 15 & $13.0 \%$ \\
\hline & DA & 14 & $26.9 \%$ & 13 & $20.6 \%$ & 27 & $23.5 \%$ \\
\hline & SD & 7 & $13.5 \%$ & 15 & $23.8 \%$ & 22 & $19.1 \%$ \\
\hline & Total & 52 & $100.0 \%$ & 63 & $100.0 \%$ & 115 & $100.0 \%$ \\
\hline
\end{tabular}

Table 63 revealed that $44.8 \%$ of the public school participants strongly agree and agree that they are afraid that the other students will laugh at them when they speak the foreign language, $12.1 \%$ neither agree nor disagree and $43.1 \%$ disagree and strongly disagree respectively, whereas $52.6 \%$ of the private school participants agree and strongly agree, $15.8 \%$ neither agree nor disagree and $31.5 \%$ disagree and strongly disagree with the same statement. Such results indicate that the majority of the participants in the public and private schools have high anxiety that makes them afraid of their peers' negative evaluation and they have no motivation and no self confidence to speak the foreign language.

Table64. Q31. Anxiety post test results

\begin{tabular}{|c|c|c|c|c|c|c|c|}
\hline \multirow[t]{3}{*}{ School } & \multirow{3}{*}{ Q31 } & \multicolumn{4}{|c|}{ Group } & \multirow{3}{*}{$\begin{array}{l}\text { Total } \\
\mathrm{N} \\
\end{array}$} & \multirow[b]{3}{*}{$\%$} \\
\hline & & \multicolumn{2}{|c|}{ Experimental } & \multicolumn{2}{|c|}{ Control } & & \\
\hline & & $\mathrm{N}$ & $\%$ & $\mathrm{~N}$ & $\%$ & & \\
\hline \multirow[t]{6}{*}{ Public } & SA & 0 & & 11 & $47.8 \%$ & 11 & $22.4 \%$ \\
\hline & A & 6 & $23.1 \%$ & 11 & $47.8 \%$ & 17 & $34.7 \%$ \\
\hline & NAND & 4 & $15.4 \%$ & 1 & $4.3 \%$ & 5 & $10.2 \%$ \\
\hline & DA & 9 & $34.6 \%$ & 0 & & 9 & $18.4 \%$ \\
\hline & SD & 7 & $26.9 \%$ & 0 & & 7 & $14.3 \%$ \\
\hline & Total & 26 & $100.0 \%$ & 23 & $100.0 \%$ & 49 & $100.0 \%$ \\
\hline \multirow[t]{6}{*}{ Private } & SA & 0 & & 1 & $4.2 \%$ & 1 & $2.0 \%$ \\
\hline & A & 0 & & 13 & $54.2 \%$ & 13 & $25.5 \%$ \\
\hline & NAND & 4 & $14.8 \%$ & 4 & $16.7 \%$ & 8 & $15.7 \%$ \\
\hline & DA & 10 & $37.0 \%$ & 3 & $12.5 \%$ & 13 & $25.5 \%$ \\
\hline & SD & 13 & $48.1 \%$ & 3 & $12.5 \%$ & 16 & $31.4 \%$ \\
\hline & Total & 27 & $100.0 \%$ & 24 & $100.0 \%$ & 51 & $100.0 \%$ \\
\hline \multirow[t]{6}{*}{ Total } & SA & 0 & & 12 & $25.5 \%$ & 12 & $12.0 \%$ \\
\hline & A & 6 & $11.3 \%$ & 24 & $51.1 \%$ & 30 & $30.0 \%$ \\
\hline & NAND & 8 & $15.1 \%$ & 5 & $10.6 \%$ & 13 & $13.0 \%$ \\
\hline & DA & 19 & $35.8 \%$ & 3 & $6.4 \%$ & 22 & $22.0 \%$ \\
\hline & SD & 20 & $37.7 \%$ & 3 & $6.4 \%$ & 23 & $23.0 \%$ \\
\hline & Total & 53 & $100.0 \%$ & 47 & $100.0 \%$ & 100 & $100.0 \%$ \\
\hline
\end{tabular}


Table 64 results of the anxiety posttest revealed that $23.1 \%$ of the participants in the public experimental group agree with that they are afraid that the other students will laugh at them when they speak the foreign language, $15.4 \%$ of the participants neither agree nor disagree and $61.5 \%$ of the participants disagree and strongly disagree respectively, while in the control group, $95.6 \%$ of the participants agree and strongly agree, $4.3 \%$ of the participants neither agree nor disagree, and $0 \%$ disagree with the same statement. Whereas $0 \%$ of the participants in the private experimental group agree and strongly agree with the tested statement, $14.8 \%$ neither agree nor disagree and $85.2 \%$ of the participants disagree, while in the control group, $58.4 \%$ of the participants agree, $16.7 \%$ neither agree nor disagree, and $25 \%$ disagree with the statement. Such differences in the results between the control and experimental groups indicate that anxiety has dramatically decreased in the experimental groups and almost all the participants became more responsible, more motivated and dont fear their peers' negative evaluation due to their high confidence towards speaking the foreign language after implementing the CLL approach for six months.

Table65. Q32. Anxiety pre test

\begin{tabular}{|c|c|c|c|c|c|c|c|}
\hline \multirow[t]{3}{*}{ School } & \multirow[t]{3}{*}{ Q32. } & \multicolumn{4}{|c|}{ Group } & \multirow{3}{*}{$\begin{array}{l}\text { Total } \\
\mathrm{N}\end{array}$} & \multirow[b]{3}{*}{$\%$} \\
\hline & & \multicolumn{2}{|c|}{ Experimental } & \multicolumn{2}{|c|}{ Control } & & \\
\hline & & $\mathrm{N}$ & $\%$ & $\mathrm{~N}$ & $\%$ & & \\
\hline \multirow[t]{6}{*}{ Public } & SA & 5 & $19.2 \%$ & 3 & $9.4 \%$ & 8 & $13.8 \%$ \\
\hline & $\mathrm{A}$ & 0 & & 5 & $15.6 \%$ & 5 & $8.3 \%$ \\
\hline & NAND & 8 & $30.8 \%$ & 15 & $46.9 \%$ & 23 & $39.7 \%$ \\
\hline & DA & 3 & $11.5 \%$ & 7 & $21.9 \%$ & 10 & $17.2 \%$ \\
\hline & SD & 10 & $38.5 \%$ & 2 & $6.3 \%$ & 12 & $20.7 \%$ \\
\hline & Total & 26 & $100.0 \%$ & 32 & $100.0 \%$ & 58 & $100.0 \%$ \\
\hline \multirow[t]{6}{*}{ Private } & SA & 5 & $19.2 \%$ & 9 & $28.1 \%$ & 14 & $24.2 \%$ \\
\hline & $\mathrm{A}$ & 0 & & 6 & $18.8 \%$ & 6 & $10.3 \%$ \\
\hline & NAND & 4 & $15.4 \%$ & 6 & $18.7 \%$ & 10 & $17.3 \%$ \\
\hline & DA & 10 & $38.5 \%$ & 9 & $28.1 \%$ & 19 & $32.8 \%$ \\
\hline & SD & 7 & $26.9 \%$ & 2 & $6.3 \%$ & 9 & $15.5 \%$ \\
\hline & Total & 26 & $100.0 \%$ & 32 & $100.0 \%$ & 58 & $100.0 \%$ \\
\hline \multirow[t]{6}{*}{ Total } & SA & 10 & $19.2 \%$ & 12 & $18.8 \%$ & 22 & $19.0 \%$ \\
\hline & $\mathrm{A}$ & 20 & $38.5 \%$ & 18 & $28.1 \%$ & 38 & $32.8 \%$ \\
\hline & NAND & 15 & $28.8 \%$ & 21 & $32.8 \%$ & 36 & $31.0 \%$ \\
\hline & DA & 3 & $5.8 \%$ & 9 & $14.1 \%$ & 12 & $10.3 \%$ \\
\hline & SD & 4 & $7.7 \%$ & 4 & $6.3 \%$ & 8 & $6.9 \%$ \\
\hline & Total & 52 & $100.0 \%$ & 64 & $100.0 \%$ & 116 & $100.0 \%$ \\
\hline
\end{tabular}

Table 65 revealed that $22.1 \%$ of the public school participants strongly agree and agree that they would probably feel comfortable around native speakers of the foreign language, 39.7\% neither agree nor disagree and $37.9 \%$ disagree and strongly disagree respectively with the statement whereas $34.5 \%$ of the private school participants agree and strongly disagree, $17.3 \%$ neither agree nor disagree and $48.2 \%$ disagree and strongly disagree with the same statement. Such results indicate that the majority of the participants in the public and private schools have moderate to high anxiety, low self confidence towards being around native speakers of the foreign language, demotivated and irresponsible towards the FL class.

Table66. Q32. Anxiety post test results

\begin{tabular}{|l|l|l|l|l|l|l|l|}
\hline School & Q32. & \multicolumn{2}{|c|}{ Group } & Total & \\
\hline & & \multicolumn{2}{|c|}{ Experimental } & \multicolumn{2}{|c|}{ Control } & & \\
\hline \multirow{5}{*}{ Public } & & $\mathrm{N}$ & $\%$ & $\mathrm{~N}$ & $\%$ & $\mathrm{~N}$ & $\%$ \\
& $\mathrm{SA}$ & 2 & $7.7 \%$ & 0 & & 2 & $4.1 \%$ \\
\cline { 2 - 8 } & $\mathrm{A}$ & 14 & $53.8 \%$ & 0 & & 14 & $28.6 \%$ \\
\cline { 2 - 8 } & NAND & 10 & $38.5 \%$ & 0 & & 10 & $20.4 \%$ \\
\cline { 2 - 8 } & DA & 0 & & 11 & $47.8 \%$ & 11 & $22.4 \%$ \\
\cline { 2 - 8 } & SD & 0 & & 12 & $52.2 \%$ & 12 & $24.5 \%$ \\
\cline { 2 - 8 } & Total & 26 & $100.0 \%$ & 23 & $100.0 \%$ & 49 & $100.0 \%$ \\
\hline \multirow{5}{*}{ Private } & SA & 9 & $33.3 \%$ & 4 & $16.7 \%$ & 13 & $25.5 \%$ \\
\cline { 2 - 8 } & A & 11 & $40.7 \%$ & 2 & $8.3 \%$ & 13 & $25.5 \%$ \\
\cline { 2 - 8 } & NAND & 2 & $7.4 \%$ & 9 & $37.5 \%$ & 11 & $21.5 \%$ \\
\cline { 2 - 8 } & DA & 5 & $18.5 \%$ & 8 & $33.3 \%$ & 13 & $25.5 \%$ \\
\hline
\end{tabular}


Could Cll Approach be a Remedy for Tripoli Secondary Students Speaking Skills?

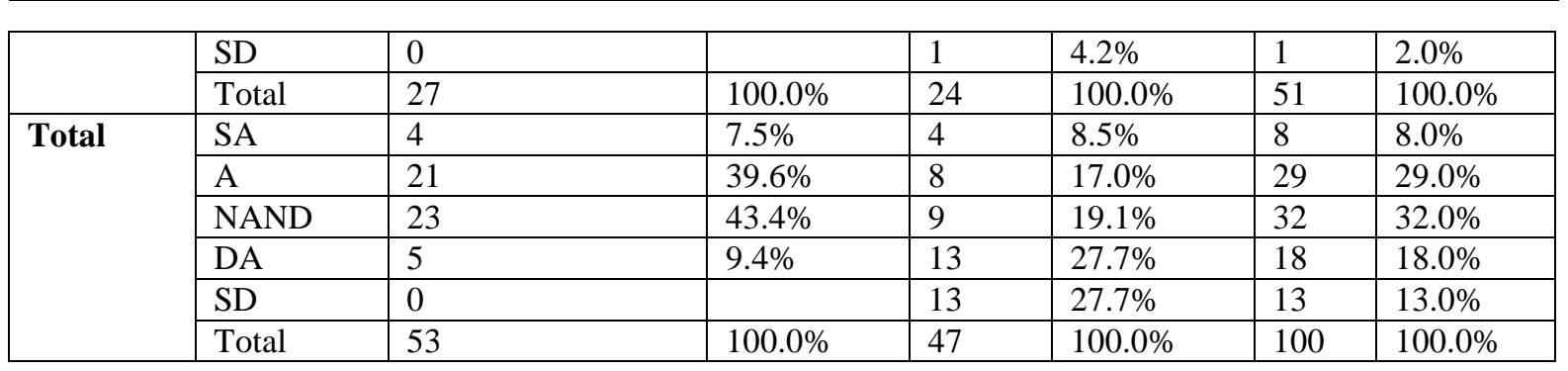

Table 66 of the anxiety posttest revealed that $61.5 \%$ of the participants in the public experimental group strongly agree and agree with that they would probably feel comfortable around native speakers of the foreign language, $38.5 \%$ of the participants neither agree nor disagree and $0 \%$ of the participants disagree and strongly disagree respectively, while in the control group, $0 \%$ of the participants agree and strongly agree, $0 \%$ of the participants neither agree nor disagree, and $100 \%$ disagree with the statement. Whereas $74 \%$ of the participants in the private experimental group agree and strongly agree with the tested statement, $7.4 \%$ neither agree nor disagree and $8.5 \%$ of the participants disagree with it, while in the control group, $25 \%$ of the participants agree, $37.5 \%$ neither agree nor disagree and $37.5 \%$ disagree with the same statement. Such differences in the results between the control and experimental groups indicate that anxiety has dramatically decreased in the experimental groups and almost all the participants became more responsible, more motivated and more confident towards being around native speakers of the foreign language.

Table67. Q33. Anxiety pre test

\begin{tabular}{|c|c|c|c|c|c|c|c|}
\hline \multirow[t]{3}{*}{ School } & \multirow[t]{3}{*}{ Q33. } & \multicolumn{4}{|c|}{ Group } & \multicolumn{2}{|c|}{ Total } \\
\hline & & \multicolumn{2}{|c|}{ Experimental } & \multicolumn{2}{|r|}{ Control } & & \\
\hline & & $\mathrm{N}$ & $\%$ & $\mathrm{~N}$ & $\%$ & $\mathrm{~N}$ & $\%$ \\
\hline \multirow{6}{*}{ Public } & SA & 4 & $15.4 \%$ & 1 & $3.1 \%$ & 5 & $8.6 \%$ \\
\hline & A & 9 & $34.6 \%$ & 9 & $28.1 \%$ & 18 & $31.0 \%$ \\
\hline & NAND & 5 & $19.2 \%$ & 8 & $25.0 \%$ & 13 & $22.4 \%$ \\
\hline & DA & 6 & $23.1 \%$ & 12 & $37.5 \%$ & 18 & $31.0 \%$ \\
\hline & SD & 2 & $7.7 \%$ & 2 & $6.3 \%$ & 4 & $6.9 \%$ \\
\hline & Total & 26 & $100.0 \%$ & 32 & $100.0 \%$ & 58 & $100.0 \%$ \\
\hline \multirow{6}{*}{ Private } & SA & 5 & $19.2 \%$ & 1 & $3.1 \%$ & 6 & $10.3 \%$ \\
\hline & A & 7 & $26.9 \%$ & 9 & $28.1 \%$ & 16 & $27.6 \%$ \\
\hline & NAND & 1 & $3.8 \%$ & 7 & $21.9 \%$ & 8 & $13.8 \%$ \\
\hline & DA & 9 & $34.6 \%$ & 7 & $21.9 \%$ & 16 & $27.6 \%$ \\
\hline & SD & 4 & $15.4 \%$ & 8 & $25.0 \%$ & 12 & $20.7 \%$ \\
\hline & Total & 26 & $100.0 \%$ & 32 & $100.0 \%$ & 58 & $100.0 \%$ \\
\hline \multirow[t]{6}{*}{ Total } & SA & 9 & $17.3 \%$ & 2 & $3.1 \%$ & 11 & $9.5 \%$ \\
\hline & A & 16 & $30.8 \%$ & 18 & $28.1 \%$ & 34 & $29.3 \%$ \\
\hline & NAND & 6 & $11.5 \%$ & 15 & $23.4 \%$ & 21 & $18.1 \%$ \\
\hline & DA & 15 & $28.8 \%$ & 19 & $29.7 \%$ & 34 & $29.3 \%$ \\
\hline & SD & 6 & $11.5 \%$ & 10 & $15.6 \%$ & 16 & $13.8 \%$ \\
\hline & Total & 52 & $100.0 \%$ & 64 & $100.0 \%$ & 116 & $100.0 \%$ \\
\hline
\end{tabular}

Table 67 revealed that $39.6 \%$ of the public school participants strongly agree and agree that they get nervous when the foreign language teacher asks questions which they haven't prepared in advance, $22.4 \%$ neither agree nor disagree and $37.9 \%$ disagree and strongly disagree respectively with the statement, whereas $37.9 \%$ of the private school participants agree and strongly disagree, $13.8 \%$ neither agree nor disagree, and $48.3 \%$ disagree and strongly disagree with the same statement. Such results indicate that the majority of the participants in the public school have moderate anxiety, low confidence and low motivation that make them feel nervous when the foreign language teacher asks questions which they haven't prepared in advance. Whereas the majority of the private school participants have lower anxiety, more motivation and confidence in their foreign language.

Table68. Q33. Anxiety post test results

\begin{tabular}{|c|c|c|c|c|c|c|c|}
\hline School & Q33 & \multicolumn{4}{|c|}{ Group } & \multicolumn{2}{|c|}{ Total } \\
\hline & & \multicolumn{2}{|c|}{ Experimental } & \multicolumn{2}{|c|}{ Control } & & \\
\hline & & $\mathrm{N}$ & $\%$ & $\mathrm{~N}$ & $\%$ & $\mathrm{~N}$ & $\%$ \\
\hline \multirow[t]{2}{*}{ Public } & SA & 0 & & 14 & $60.9 \%$ & 14 & $28.6 \%$ \\
\hline & A & 5 & $19.2 \%$ & 4 & $17.4 \%$ & 9 & $18.4 \%$ \\
\hline
\end{tabular}


Could Cll Approach be a Remedy for Tripoli Secondary Students Speaking Skills?

\begin{tabular}{|c|c|c|c|c|c|c|c|}
\hline & NAND & 5 & $19.2 \%$ & 1 & $4.3 \%$ & 6 & $12.2 \%$ \\
\hline & DA & 12 & $46.2 \%$ & 2 & $8.7 \%$ & 14 & $28.6 \%$ \\
\hline & SD & 4 & $15.4 \%$ & 2 & $8.7 \%$ & 6 & $12.2 \%$ \\
\hline & Total & 26 & $100.0 \%$ & 23 & $100.0 \%$ & 49 & $100.0 \%$ \\
\hline \multirow[t]{6}{*}{ Private } & SA & 0 & & 3 & $12.5 \%$ & 3 & $5.9 \%$ \\
\hline & A & 2 & $7.4 \%$ & 5 & $20.8 \%$ & 7 & $13.7 \%$ \\
\hline & NAND & 6 & $22.2 \%$ & 4 & $16.7 \%$ & 10 & $19.6 \%$ \\
\hline & DA & 18 & $66.7 \%$ & 8 & $33.3 \%$ & 26 & $51.0 \%$ \\
\hline & SD & 1 & $3.7 \%$ & 4 & $16.7 \%$ & 5 & $9.8 \%$ \\
\hline & Total & 27 & $100.0 \%$ & 24 & $100.0 \%$ & 51 & $100.0 \%$ \\
\hline \multirow[t]{6}{*}{ Total } & SA & 0 & & 17 & $36.2 \%$ & 17 & $17.0 \%$ \\
\hline & A & 7 & $13.2 \%$ & 9 & $19.1 \%$ & 16 & $16.0 \%$ \\
\hline & NAND & 11 & $20.8 \%$ & 5 & $10.6 \%$ & 16 & $16.0 \%$ \\
\hline & DA & 30 & $56.6 \%$ & 10 & $21.3 \%$ & 40 & $40.0 \%$ \\
\hline & SD & 5 & $9.4 \%$ & 6 & $12.8 \%$ & 11 & $11.0 \%$ \\
\hline & Total & 53 & $100.0 \%$ & 47 & $100.0 \%$ & 100 & $100.0 \%$ \\
\hline
\end{tabular}

Table 68 of the anxiety posttest revealed that $19.2 \%$ of the participants in the public experimental group agree with that they get nervous when the foreign language teacher asks questions which they haven't prepared in advance, $19.2 \%$ of the participants neither agree nor disagree with the statement and $61.6 \%$ of the participants disagree and strongly disagree respectively, while in the control group, $78.3 \%$ of the participants agree and strongly agree , $4.3 \%$ of the participants neither agree nor disagree and $17.4 \%$ disagree with the same statement. Whereas $7.4 \%$ of the participants in the private experimental group agree with the tested statement, $22.2 \%$ neither agree nor disagree and $70.4 \%$ of the participants disagree with it, while in the control group, $33.3 \%$ of the participants agree, $16.7 \%$ neither agree nor disagree, and 50\% disagree with it. Such differences in the results between the control and experimental groups indicate that anxiety has dramatically decreased in the experimental groups and almost all the participants became more responsible, more motivated and more confident to answer the foreign language teacher questions which they haven't prepared in advance.

Table69. Pre anxiety

\begin{tabular}{|l|l|l|l|l|}
\hline core & \multicolumn{5}{|l|}{ School } \\
\hline & Public & Private \\
\hline & $\mathrm{N}$ & $\%$ & $\mathrm{~N}$ & $\%$ \\
\hline$(\mathbf{0 - 2 . 5})$ & 7 & $12.1 \%$ & 1 & $1.7 \%$ \\
\hline $\mathbf{( 2 . 5 - 3 . 5 )}$ & 47 & $81.0 \%$ & 52 & $88.1 \%$ \\
\hline$(\mathbf{3 . 5}-5)$ & 4 & $6.9 \%$ & 6 & $10.2 \%$ \\
\hline Total & 58 & $100.0 \%$ & 59 & $100.0 \%$ \\
\hline
\end{tabular}

Table 69 demonstrated students` distribution of anxiety levels according to FLCAS pre- questionnaire results where $81.0 \%$ of the public students were ranged between (2.5-3.5) which indicated a moderate level of anxiety, $12.1 \%$ ranged between (0-2.5) which indicates a low level of anxiety and $6.9 \%$ had a high anxiety level ranged between (3.5-5). Whereas, $88.1 \%$ of the private students ranged between (2.5-3.5) which indicated a moderate anxiety level, $1.7 \%$ had a low anxiety level ranged between (0-2.5) and $10.2 \%$ had a high anxiety level ranged between (3.5-5).

After conducting the CLL approach for six months in the experimental groups in both schools, the FLCAS questionnaire was applied at the end of the second semester to measure their speaking anxiety level and their perceptions towards the foreign language.

Table70. Post anxiety

\begin{tabular}{|l|l|l|l|l|}
\hline \multicolumn{4}{|c|}{ School } \\
\hline \multicolumn{2}{|c|}{ Public } & \multicolumn{3}{c|}{ Private } \\
\hline $\mathrm{N}$ & $\%$ & 19 & $\%$ \\
\hline 17 & $34.7 \%$ & 32 & $37.3 \%$ \\
\hline 20 & $40.8 \%$ & 0 & $62.7 \%$ \\
\hline 12 & $24.5 \%$ & 51 & $0.0 \%$ \\
\hline 49 & $100.0 \%$ & $100.0 \%$ \\
\hline
\end{tabular}

Table 70 demonstrated the changes occurred in students` levels of speaking anxiety according to the post questionnaire results. As presented in table 70, the percentage of moderate anxiety students in the 
public experimental group decreased to become after the intervention of CLL $40.8 \%$ instead of 81.0 $\%$ presented in the pretest ranging between (2.5-3.5), whereas the percentage of moderate anxiety students in the private experimental group decreased but not to the same extent of the public group, to become $62.7 \%$ instead of $88.1 \%$ of presented in the pretest ranging between (2.5-3.5). Moreover, it is noticed that $34.7 \%$ of the public school students had a low anxiety level with a mean score of (02.5 ) instead of $12.1 \%$ before implementing the CLL. Whereas $37.3 \%$ of the private school students had a low anxiety level with a mean score of $(0-2.5)$ instead of $1.7 \%$ before implementing the CLL. This increase in percentages indicated that the CLL approach have decreased the students` anxiety level.

\section{Data Analyses of the FLCAS Recognition Level}

Table71. Pre-test $\backslash$ Public students' anxiety levels

\begin{tabular}{|l|l|l|l|l|}
\hline Score_Cat & & Group & Total & \\
\hline & & Experimental & Control & \\
\hline $\mathbf{( 0 - 2 . 5 )}$ & $\mathrm{N}$ & 17 & 0 & 17 \\
\hline & $\%$ & $65.4 \%$ & $0.0 \%$ & $34.7 \%$ \\
\hline $\mathbf{( 2 . 5 - 3 . 5 )}$ & $\mathrm{N}$ & 9 & 11 & 20 \\
\hline & $\%$ & $34.6 \%$ & $47.8 \%$ & $40.8 \%$ \\
\hline $\mathbf{( 3 . 5 - 5 )}$ & $\mathrm{N}$ & 0 & 12 & 12 \\
\hline & $\%$ & $0.0 \%$ & $24.5 \%$ & $24.5 \%$ \\
\hline Total & $\mathrm{N}$ & 26 & 23 & 49 \\
\hline & $\%$ & $100.0 \%$ & $100.0 \%$ & $100.0 \%$ \\
\hline
\end{tabular}

$P$-value $=0.05$

Significant relation

Table 71 showed that the number of students is 26 in the experimental group, and 32 in the control group. Although P-value is significant with $0.05,81.1 \%$ of the public students in both control and experimental groups were of moderate language anxiety level ranged between (2.5-3.5) which indicate no differences between both groups at the beginning of the study.

Table72. Post-test Public students' anxiety levels

\begin{tabular}{|l|l|l|l|l|}
\hline \multirow{2}{*}{ Score_Cat } & \multicolumn{3}{|l|}{ Group } & Total \\
\cline { 2 - 5 } & & Experimental & Control & \\
\hline \multirow{2}{*}{$(\mathbf{0 - 2 . 5})$} & $\mathrm{N}$ & 6 & 1 & 7 \\
\cline { 2 - 5 } & $\%$ & $23.1 \%$ & $3.1 \%$ & $12.1 \%$ \\
\hline \multirow{2}{*}{$(\mathbf{2 . 5 - 3 . 5 )}$} & $\mathrm{N}$ & 19 & 28 & 47 \\
\cline { 2 - 5 } & $\%$ & $73.1 \%$ & $87.5 \%$ & $81.0 \%$ \\
\hline \multirow{3}{*}{ (3.5-5) } & $\mathrm{N}$ & 1 & 3 & 4 \\
\cline { 2 - 5 } & $\%$ & $3.8 \%$ & $9.4 \%$ & $6.9 \%$ \\
\hline & $\mathrm{N}$ & 26 & 32 & 58 \\
\cline { 2 - 5 } & $\%$ & $100.0 \%$ & $100.0 \%$ & $100.0 \%$ \\
\hline
\end{tabular}

$P$-value $<0.0001$

Significant relation

Table 72 showed the results of the post tests in both experimental and control groups in the public school after implementing the CLL approach for six months in the experimental group. The table presented a significant relation with a P-value $<0.0001$ which indicate no differences between both groups at the beginning of the study. The table above showed the number of experimental group students was 26 while the control group students 23 . Moreover, the experimental group results of the post-test showed a high deviation from $73.2 \%$ to $34.6 \%$ for the mean score of (2.5-3.5) which indicates that less students are having moderate language anxiety. Whereas the highest significant deviation was from $23.1 \%$ to $65.4 \%$ for the mean of $(0-2.5)$ which indicates that after implementing the CLL many students dropped their anxiety to become low anxiety level that is considered by many authors as positive anxiety.

Table73. Pre-test $\backslash$ Private students' anxiety levels

\begin{tabular}{|l|l|l|l|l|}
\hline \multirow{2}{*}{ Score_Cat } & \multicolumn{3}{|c|}{ Group } & Total \\
\cline { 2 - 5 } & & Experimental & Control & \\
\hline \multirow{2}{*}{$\mathbf{0 - 2 . 5 )}$} & $\mathrm{N}$ & 1 & 0 & 1 \\
\cline { 2 - 5 } & $\%$ & $3.7 \%$ & $0.0 \%$ & $1.7 \%$ \\
\hline
\end{tabular}




\begin{tabular}{|c|c|c|c|c|}
\hline \multirow[t]{2}{*}{$(2.5-3.5)$} & $\mathrm{N}$ & 24 & 28 & 52 \\
\hline & $\%$ & $88.9 \%$ & $87.5 \%$ & $88.1 \%$ \\
\hline \multirow[t]{2}{*}{$(3.5-5)$} & $\mathrm{N}$ & 2 & 4 & 6 \\
\hline & $\%$ & $7.4 \%$ & $12.5 \%$ & $10.2 \%$ \\
\hline \multirow[t]{2}{*}{ Total } & $\mathrm{N}$ & 27 & 32 & 59 \\
\hline & $\%$ & $100.0 \%$ & $100.0 \%$ & $100.0 \%$ \\
\hline
\end{tabular}

$\mathrm{P}$-value $=0.458$

Not Significant relation

Table 73 indicated that the number of experimental group students is 27 , and the control group is 32 . The pre-test showed that $88.1 \%$ of the private students in both the control and experimental groups had the same mean of (2.5-3.5) which indicated a moderate language anxiety level and the Pvalue $=0.458$ showed no significant relation which indicated that there are no differences between both groups at the beginning of the study.

Table74. Post-test $\backslash$ Private students' anxiety levels

\begin{tabular}{|l|l|l|l|l|}
\hline \multirow{2}{*}{ Score_Cat } & \multicolumn{3}{|l|}{ Group } & Total \\
\cline { 2 - 5 } & & Experimental & Control & \\
\hline \multirow{2}{*}{$(\mathbf{0 - 2 . 5 )}$} & $\mathrm{N}$ & 19 & 0 & 19 \\
\cline { 2 - 5 } & $\%$ & $70.4 \%$ & $0.0 \%$ & $37.3 \%$ \\
\hline \multirow{2}{*}{ (2.5-3.5) } & $\mathrm{N}$ & 8 & 24 & 32 \\
\cline { 2 - 5 } & $\%$ & $29.6 \%$ & $100.0 \%$ & $62.7 \%$ \\
\hline \multirow{2}{*}{ Total } & $\mathrm{N}$ & 27 & 24 & 51 \\
\cline { 2 - 5 } & $\%$ & $100.0 \%$ & $100.0 \%$ & $100.0 \%$ \\
\hline
\end{tabular}

P-value $<0.0001$

Significant relation

Table 74 showed the results of the post tests in both experimental and control groups in the private school after implementing the CLL approach for six months. The results in this same table indicated a significant relation with P-value $<0.0001$ between experimental students ( 27), and control group ( $24)$. The results of the experimental group post-test showed a high deviation from $88.9 \%$ to $29.6 \%$ for the mean score of (2.5-3.5) which indicated that less students are having a moderate language anxiety. Whereas the highest significant deviation was from $3.7 \%$ to $70.4 \%$ for the mean of $(0-2.5)$, which indicates that after implementing the CLL, more students are having lower anxiety levels.

Table75. Pre-test $₫$ public and private control anxiety level

\begin{tabular}{|c|c|c|c|c|}
\hline Score_Cat & & \multicolumn{2}{|l|}{ School } & \multirow[t]{2}{*}{ Total } \\
\hline & & Public & Private & \\
\hline$(0-2.5)$ & $\mathrm{N}$ & 7 & 1 & 8 \\
\hline & $\%$ & $12.1 \%$ & $1.7 \%$ & $6.8 \%$ \\
\hline$(2.5-3.5)$ & $\mathrm{N}$ & 47 & 52 & 99 \\
\hline & $\%$ & $81.0 \%$ & $88.1 \%$ & $84.6 \%$ \\
\hline$(3.5-5)$ & $\mathrm{N}$ & 4 & 6 & 10 \\
\hline & $\%$ & $6.9 \%$ & $10.2 \%$ & $8.5 \%$ \\
\hline Total & $\mathrm{N}$ & 58 & 59 & 117 \\
\hline & $\%$ & $100.0 \%$ & $100.0 \%$ & $100.0 \%$ \\
\hline
\end{tabular}

$P$-value $=0.076 \quad$ Not Significant relation

Table 75 showed the number of public students $=58$, and the number of private school $\mathrm{N}=59$ participated in the study. The results of pre-tests presented in table 75 indicated that both the public and the private school had the same mean of (2.5-3.5) which indicated a moderate language anxiety where the $p$-value $=0.076$ showed no significant relation and that there was no differences in students` anxiety level between both sectors at the beginning of the study.

Table76. Post-test public and private control anxiety levels

\begin{tabular}{|l|l|l|l|l|}
\hline \multirow{2}{*}{ Score_Cat } & \multicolumn{3}{|l|}{ School } & Total \\
\cline { 2 - 5 } & & Public & Private & \\
\hline \multirow{2}{*}{$(\mathbf{0 - 2 . 5 )}$} & $\mathrm{N}$ & 17 & 19 & 36 \\
\cline { 2 - 5 } & $\%$ & $34.7 \%$ & $37.3 \%$ & $36.0 \%$ \\
\hline \multirow{2}{*}{$(\mathbf{2 . 5 - 3 . 5 )}$} & $\mathrm{N}$ & 20 & 32 & 52 \\
\cline { 2 - 5 } & $\%$ & $40.8 \%$ & $62.7 \%$ & $52.0 \%$ \\
\hline
\end{tabular}




\begin{tabular}{|l|l|l|l|l|}
\hline \multirow{2}{*}{$(3.5-5)$} & $\mathrm{N}$ & 12 & 0 & 12 \\
\cline { 2 - 5 } & $\%$ & $24.5 \%$ & $0.0 \%$ & $12.0 \%$ \\
\hline \multirow{3}{*}{ Total } & $\mathrm{N}$ & 49 & 51 & 100 \\
\cline { 2 - 5 } & $\%$ & $100.0 \%$ & $100.0 \%$ & $100.0 \%$ \\
\hline
\end{tabular}

$P$-value $=0.001$

Significant relation

Table 76 demonstrated the number of public students (49) and the number of private students (51) who participated in the post test. Moreover, the table showed that $40.8 \%$ of the public school students instead of $81.0 \%$ in the pretest and $62.7 \%$ of the private school students instead of $88.1 \%$ had a mean of (2.5-3.5) which indicated that less students are having a moderate language anxiety in both sectors, and the P-value $=0.001$ with a significant relation. Whereas $34.7 \%$ instead of $12.1 \%$ of the public school students and $37.3 \%$ instead of $1.7 \%$ of the private school students were having a low anxiety level with a mean of $(0-2.5)$.

All the above tables revealed that the post-test of the control and the experimental group results, in each sector and the public and private schools had a significance relation. These results shifted from no significant relation with a $\mathrm{P}$ value of 0.076 to a significant one with a $\mathrm{P}$-value ranged between < 0.0001 and $=0.001$, and with a decrease in the mean from (3.5-5] to (2.5-3.5) among students in both sectors after implementing the CLL approach in the experimental group for six months indicated a deviation from moderate level of anxiety to a lower one.

Table77. Post-test $\backslash$ public and private experimental students' anxiety

\begin{tabular}{|l|l|l|l|l|}
\hline \multirow{2}{*}{ Score_Cat } & \multicolumn{2}{|c|}{ School } & Total \\
\cline { 2 - 5 } & & Public & Private & \\
\hline \multirow{2}{*}{$(\mathbf{0 - 2 . 5 )}$} & $\mathrm{N}$ & 17 & 19 & 36 \\
\cline { 2 - 5 } & $\%$ & $65.4 \%$ & $70.4 \%$ & $67.9 \%$ \\
\hline \multirow{2}{*}{$\mathbf{2 . 5 - 3 . 5 )}$} & $\mathrm{N}$ & 9 & 8 & 17 \\
\cline { 2 - 5 } & $\%$ & $34.6 \%$ & $29.6 \%$ & $32.1 \%$ \\
\hline $\mathbf{( 3 . 5 - 5 )}$ & $\mathrm{N}$ & 0 & 0 & 0 \\
\cline { 2 - 5 } & $\%$ & $0.0 \%$ & $0.0 \%$ & $0.0 \%$ \\
\hline \multirow{2}{*}{ Total } & $\mathrm{N}$ & 26 & 27 & 53 \\
\cline { 2 - 5 } & $\%$ & $100.0 \%$ & $100.0 \%$ & $100.0 \%$ \\
\hline
\end{tabular}

$P$-value $=0.637$

Not Significant relation

Table 77 results showed that $65.4 \%$ of the public experimental group students and $70.4 \%$ of the private experimental group students had a low anxiety level with a mean score of $(0-2.5)$, whereas $34.6 \%$ of the public experimental group students and $29.6 \%$ of the private one had a moderate anxiety level with a mean score of (2.5-3.5) which indicate that both experimental groups in both sectors have no more high level anxiety students after implementing the CLL approach. Again these results demonstrated that there are differences between students` language anxiety levels before and after implementing the CLL approach.

Table78. Posttest $\backslash$ public and private control students' anxiety

\begin{tabular}{|l|l|l|l|l|}
\hline Score_Cat & & School & Total \\
\hline & & Public & Private & \\
\hline$(\mathbf{0 - 2 . 5})$ & $\mathrm{N}$ & 0 & 0 & 0 \\
\hline & $\%$ & $0.0 \%$ & $0.0 \%$ & $0.0 \%$ \\
\hline $\mathbf{( 2 . 5 - 3 . 5 )}$ & $\mathrm{N}$ & 11 & 24 & 35 \\
\hline & $\%$ & $47.8 \%$ & $100 \%$ & $74.5 \%$ \\
\hline $\mathbf{( 3 . 5 - 5 )}$ & $\mathrm{N}$ & 12 & 0 & 12 \\
\hline & $\%$ & $24.5 \%$ & $0.0 \%$ & $25.5 \%$ \\
\hline Total & $\mathrm{N}$ & 23 & 24 & 47 \\
\hline & $\%$ & $100.0 \%$ & $100.0 \%$ & $100.0 \%$ \\
\hline
\end{tabular}

$P$-value $<0.0001$

Significant relation

Analyzing the two control groups from the public and private schools, table 78 showed a significant relation with a $\mathrm{P}$-value of $<0.0001$. It was surprising that $0.0 \%$ of the public control group students and $0.0 \%$ of the private control group students had a mean score of $(0-2.5)$ which indicated that none of them had a low anxiety level at the end of the year after implementing the traditional method in foreign language teaching. Whereas $47.8 \%$ of the public control group students and surprisingly $100 \%$ 
of the private control group students had a moderate anxiety level with a mean score of (2.5-3.5). And last but not least, $24.5 \%$ of the public control group students had high anxiety level with a mean score of (3.5-5] whereas as no student in the control private school had high anxiety level at the end of the year. Such results indicate that students of the control groups in both sectors still suffer from moderate to high anxiety levels but with a slight difference that private students outperformed the public students in the moderate level of language anxiety.

All the previous results from the table 71 to 78 could be considered as an answer to the which states: what are the differences between students' language anxiety level before and after implementing the CLL method in speaking classes for six months.

\section{DISCUSSION}

Although the existing research has provided a valuable insight into the effects of Community Language Learning on the English Foreign Language students' speaking anxiety in Tripoli secondary schools from both statistical and descriptive aspects, the topic with its complicated and multi-faceted nature, requires more exploration from a variety of perspectives. The study conducted through individual questionnaires, was such an attempt to comprehend the nature of language anxiety and the effects of CLL on EFL students' speaking anxiety in both public and private schools. Thus, the qualitative results presented in this study, indicated that although grade ten students were aware of their English language anxiety, they faced high anxiety levels provoking situations in the classroom which negatively affected their oral performance.

Based on the FLCAS pretest results in this study, the majority of the 117, G 10 students have been found suffering from speaking English anxiety that played a significant role in their education which is apparently similar to Kayaoğlu and Sağlamel (2013) who stated that a number of learners suffer from language anxiety at language classroom, and Liu's study (2006) who concluded that more than one-third of the participants in his study seemed to be anxious in Oral English classroom. Answering the research question 1 about the factors that usually affect students oral speaking, the theoretical part represented by Goshi (2005) Kara (2009), Chalak \& Kassaian (2010), and Tella, Indoshi, \& Othuon ( 2010) as well as the quantitative study results highlighted various factors behind students` English speaking anxiety. The mentioned authors found that students with negative beliefs about their learning English feel more foreign language anxiety while the FLCAS results showed that every situation that enhanced the exposure of EFL students' deficiencies and language mistakes, like open class interactions, class presentations, and short speeches that challenge their communicative abilities could be considered as primary factors behind students` language anxiety. Moreover, the speaking anxiety manifestations and coping strategies pinpointed in this study are similar to earlier research studies (e.g., Alrabai, 2014; Woodrow, 2006) except for the detailed implementation of the humanistic CLL approach in the Lebanese classrooms of Tripoli, which identified the factors behind G10 Lebanese students English speaking anxiety poor pronunciation; low proficiency in the general linguistic knowledge and the lack of sufficient input and practice, pronunciation mistakes, teacher's manner in evaluating and correcting their errors, low self-esteem, when they think that their peers are better and will laugh at them when they speak English and also from parents' intervention and pressure. All in all, they are afraid of failing the English class especially in speaking. The positive findings highlighted students` motivation to reduce their anxiety for better performance inside and outside the class which were supported by Mihaljević Djigunović (2002) who stated that the motivational factors have a great influence on reducing student's anxiety level when it comes to learning language. Thus, for a successful language learning and better oral performance, it was necessary to reduce negativity among students, raise students' self- beliefs and assist them to defeat anxiety through implementing CLL right procedures.

the quantitative phase of this study through FLCAS test scores sought to answer the second research question (What is the difference between public sector students and private sector students in acquiring the speaking skill of the foreign language, with respect to scores and anxiety level?). A key finding in this research is the differences occurred between students' level of speaking anxiety in terms of school sector, after implementing the CLL approach in speaking classes for six months, which indicated differences in students' speaking English language achievement in both Lebanese Public and Private sectors. In this sense the study results revealed that the English speaking proficiency level was similar in both public and private schools before implementing CLL approach 
which is recommended in any experimental study. Accordingly, the pretest students results in both sectors hindered almost the same moderate level of anxiety ranged between (2.5-3.5) where $(81.0 \%$ public and $88.1 \%$ private). These numbers reflect that the majority of the experimental students in both sectors perceived language anxiety which seemed similar to MacIntyre \& Gardner (1991a) who concluded that over $87 \%$ of the students suffered from anxiety, and Woodrow (2006) who concluded that $85 \%$ of the students experienced foreign language speaking anxiety. Surprisingly, the pretest results turned according to the posttest to become $40.8 \%$ and $62.7 \%$ in the public and private sectors respectively, which means that the percentage of public students who suffered from language anxiety before CLL implementation dropped down more than the percentage of private students, which means that CLL approach had more effect on public school students`anxiety than on private students` anxiety. This study results did not only show the differences between students' anxiety scores before and after implementing the CLL approach in speaking classes for six months in Tripoli secondary schools, but it also showed the differences between Public and Private school students speaking English language anxiety and the differences occurred between control and experimental groups in both sectors.

Answering the third question related to differences occurred between groups the findings indicated that although both experimental groups did not have a high anxiety students after implementing the CLL approach, differences between public and private students` anxiety continued to appear in further findings $65.4 \%$ of the public experimental group students and $70.4 \%$ of the private experimental group students had a low anxiety level with a mean score of $(0-2.5)$, whereas $34.6 \%$ of the public experimental group students and $29.6 \%$ of the private one had a moderate anxiety level with a mean score of (2.5-3.5). in the same sense, the two control group results indicated that although students of the control groups in both sectors are suffering similarly from moderate to high anxiety levels , differences between them were clear in all levels of anxiety where private students outperformed the public students in the moderate level of language anxiety, (47.8\% public $100 \%$ private) $(24.5 \%$ public $0 \%$ private) .

Moreover, this study indicated a better oral achievement after implementing the CLL approach for six months with a high correlation coefficient of 0.84 between the control and experimental groups in the private school and 0.74 in the public school. We can relate this high correlation at the private school to the fact that students' scores were slightly better from the beginning and due to the fact that public students` oral grades were lower. It was noticed as well that the CLL approach worked more with the weakest students who had low grades whereas those with good ones maintained the same ones. Through all what was happening and all what students achieve could be related to the good performance of the students with a greater role of the teachers and a better view to the Public secondary schools in Tripoli where less attention was given to them.

The findings of this study confirmed that the speaking anxiety in the Lebanese classroom must be recognized as very important in foreign language instructional settings and students with English speaking anxiety must be supported to become active learners (Horwitz et al., 1986). In order to strengthen the flexibility of the Lebanese Public and Private high school students, and in order to overcome and reduce the factors of language anxiety, it is necessary that the educational system and precisely the teachers help in creating an appropriate student centered classroom environment using the community language learning approach to address the pressures experienced by Lebanese EFL students and lead to a lower speaking anxiety. Moreover, the best to mention is that CLL approach has dramatic effects on language learning being a student-centered method that focuses on oral speaking skills where the teacher`s role is to act as a facilitator, advisor and co-communicator.

Finally, it is worth to mention that the activities conducted in the Community language method shaded light on the importance of the new role of the teachers and how they should change their attitudes toward students` fallacies during English classes, students' understanding of the subject, achievement levels, and create a friendly atmosphere away from anxiety that in turn stimulates language learning as well as the interpersonal and team skills.

\section{CONCLUSION AND RECOMMENDATION}

As noted earlier, the aim of this study was to investigate the impact of CLL approach on G10 students` speaking anxiety in two public and private secondary schools in Tripoli Lebanon. More objectives were examined in terms of the factors that students are affected by while expressing 
themselves using the foreign language and the differences occurred between the public students' speaking English language anxiety and those in the private sector. The qualitative approach presented by the pre $\backslash$ post FLCAS questionnaire helped in collecting and analyzing data.

Generally speaking, the students displayed positive results in reducing their speaking anxiety in both public and private sectors after conducting the CLL approach for six months. The study pinpointed the fact that teaching EFL skills using CLL is efficient to improve students` speaking abilities and decrease their speaking anxiety levels when practiced in an updated learning environment away from traditional teaching methods. Moreover, the study proved by statistics that implementing CLL in English language speaking classes encouraged students to participate to the extent of using both the foreign language and their mother tongue to express themselves which contradicts their regular attitudes during traditional speaking classes in which they avoid speaking in class for many personal reasons. Consequently, when students feel at ease, not worried about the reactions of their peers and teachers towards their mistakes, they feel courageous to participate and communicate using English. Students attitude towards this approach of learning to speak English with no hesitation, fear or worries was reflected through their post test results that revealed students`improvement in lowering their anxiety in most of the factors. Thus, the study emphasized implementing the CLL approach in speaking classes to help students reduce their foreign language speaking anxiety that requires the right instruction with effective proficiency to guide students and encourage them to be involved in communicative speaking activities.

Consequently, one might consider the implications of the study findings are important for proficient linguistics and foreign language acquisitions. Thus, the triggers of speaking anxiety in EFL Lebanese students, the interaction between linguistics, psychological, and socio-contextual constructs, the effects of the community language learning approach on students` oral achievement and the differences in anxiety levels between private and public Tripoli high schools found in this study present challenges to the English Foreign Language Lebanese curriculum development and the design and the structure of learning resources.

A straight forward implication of the findings is that CLL can be a very productive approach to reduce secondary students`English speaking anxiety. The different creative activities conducted in this study led students to develop their oral skills that helped achieving better scores in FLCAS. Thus, implementing CLL approach fostered students to overcome their speaking deficiencies and participate not fearing students` laughter or teachers` mean comments. Furthermore, we can say that the process followed in this study emphasized the differences occurred in students scores before and after implementing CLL approach, and the differences occurred between students` scores in both sectors; public and private before and after implementing the CLL approach, as well as the differences occurred between control groups and experimental groups in both private and public sectors before and after implementing CLL approach. The process followed in this study paved the way for students to develop speaking skills and their attitude toward English language learning. The success of this study lies in developing students`speaking abilities and reducing their speaking anxiety level through creating a communicative learning environment in which the teacher is supporting facilitating guiding and directing students in a friendly way. Not only that, but the various types of group activities presentations discussions, role play conversation and dialogue that helped students to learn and express what they wanted using the English language, away from worries and fear of making mistakes. Although the study results showed the development of students` speaking skills and the reduction of their speaking anxiety the present study indicated that the period of 6 months implementing CLL was not enough as this method needs more time to show the best of results. These findings highlighted the importance of focusing on the communicative approach to practice speaking the foreign language, rather than having only speaking sessions guided by the traditional method classes. Not to forget students` motivation to overcome their English speaking obstacles guided and corrected by a nice attitude teacher that avoided hurting or humiliating any student for a committed mistake. It is hoped that this paper would offer teachers dealing with English language learners the suitable speaking strategies, one of which, integrating CLL approach in teaching speaking, which arises students` motivation and reduces their speaking anxiety. 


\section{LIMITATIONS AND RECOMMENDATIONS}

Nevertheless, the limitations to over generalizing these findings should be avoided as the study is limited to 117 G10 students belonged to two coeducation schools in Tripoli Lebanon. Further studies are required to overcome the limitations of the present study and to produce more convincing evidence of the importance of focusing on students` speaking anxiety in contexts of EFL courses. Finally, it is hoped as well that this paper suggests a considerable addition to the existing literature as far as Community language learning approach in English as a foreign language is concerned.

\section{REFERENCES}

[1] Al-Mekhlafi, A., \& Ramani, P. (2011). Expectation versus reality: Communicative approach to EFL teaching. Studies in Learning, Evaluation, Innovation \& Development, 8(1), 98-113.

[2] Alrabai, F. (2014). The influence of teacher's anxiety- reducing strategies on learners' foreign language anxiety, innovation in language learning and teaching. Routledge Doi: 10.1080/17501229.2014.890203

[3] Anderson, J. (1993). Is a communicative approach practical for teaching English in China? Pros and cons. System, 21(4), 471-480.

[4] Ary, D., Jacobs, L., Razavieh, A., \& Sorensen, C. (2010). Introduction to research in anxiety: Issues in the mainstream classroom. Research in the Teaching of English, 36,327-355

[5] Asassfeh, S. M., Khwaileh, F. M., Al-Shaboul, Y. M., \& Alshboul, S. S. (2012). Communicative language teaching in an EFL context: Learners' attitudes and perceived implementation. Journal of Language Teaching and Research, 3(3), 525-535.

[6] Awan, R.U.N., Azher, M. Anwar, M.N., \& Naz, A., (2010). An Investigation of Foreign Language Classroom Anxiety and its Relationship with Students' Achievement. Journal of Collage Teaching \& Learning, 7,33-34. Retrieved from www.journals.cluteonline.com/index.php/TLC/article/.../249/239.

[7] Awan, R., Azher, M., Anwar, M., \& Naz, A. (2010). An investigation of foreign language classroom anxiety and its relationship with students' achievement. Journal of College Teaching \& Learning, 7(11), 33-40. Retrieved from EBSCO host.

[8] Ayres, J.A. Daly, T. Hop \&, J.C. McCroskey (Eds), avoiding communication: Shyness, reticence, and communication apprehension (2md ed., pp. 75-108). Cress Kill, NJ: Hampton Press.

[9] Betsabé Navarro Romero , (2011). Improving Speaking Skills. Encuentro, 18, pp. 86-90 .

[10] Brown, H. D. (2007a). Principles of language learning and teaching (5th ed.). New York: Pearson Education.

[11] Butler, Y. G. (2011). The implementation of communicative and task-based language teaching in the AsiaPacific region. Annual Review of Applied Linguistics, 31, 36-57.

[12] Chang, H. C. (2014). Motivating TVES nursing students: Effects of CLT on learner motivation. Chang Gung Journal of Humanities and Social Sciences, 7(1), 75-101.

[13] Chiang, M. C. (2012). The relationship between foreign language anxiety and foreign language speaking proficiency among elementary school students in Taiwan (Doctoral dissertation, Ming Chuan University).

[14] Christ, T. W., \& Makarani, S. A. (2009). Teachers' attitudes about teaching English in India: An embedded mixed methods study. International Journal of Multiple Research Approaches, 3(1), 73-87.

[15] Chung, I. F. \& Huang, Y. C. (2009). The implementation of communicative language teaching: An investigation of students' viewpoints. The Asia-Pacific Education Researcher 18(1), 67-78.

[16] Corbett, J. (2003). An intercultural approach to English language teaching. Clevedon: Multilingual Matters.

[17] Çubukçu, F. (2008). A study on the correlation between self-efficacy and foreign language learning anxiety. Journal of Theory and Practice in Education. Çanakkale Onsekiz Mart University, Faculty of Education, 4 (1):148-158.

[18] Diana Larsen-Freeman (2000). Techniques and principles in Language Teaching ( $2^{\text {nd }}$ Ed.). Oxford, New York.

[19] Echevarria, J., \& Vogt, M. (2000). 99 ideas and activities for teaching English learners with the SIOP model. Allyn \& Bacon, Boston, Mass.education (7th ed.). Canada: Thomson Wadswort

[20] Elkhafaifi, H. (2005). Listening comprehension and anxiety in the Arabic language classroom. Modern Language Journal, 89(9), 206-220

[21] Gregersen, T., \& Horwitz, E.K. (2002). Language Learning and Perfectionism: anxious and non- anxious language learners' reactions to their own oral performance. [ Article]. Modern Language Journal, 86(4), 562-570.

[22] Herreid, C. Schiller, N. (2013). Case studies and the flipped classroom. Journal of College Science Teaching, 42 (5), 62-65. 
[23] Ho W. K. (2002). English language teaching in East Asia today: An overview. Asia Pacific Journal of Education, 22(2), 1-22, DOI: 10.1080/0218879020220203

[24] Horwitz, E. K. (2001). Language anxiety and achievement. Annual Review of Applied

[25] Horwitz, E.K, Horwitz, M.B., \& Cope. J. (1986).Foreign Language Classroom Anxiety. [Article]. Modern Language Journal, $70920,125-132$.

[26] Horwitz, E.K. (1986). Foreign Language Classroom Anxiety. Modern Language Journal, 70(2), 125-132.

[27] Horwitz, E.K. (1991). "Preliminary Evidence for the Reliability and Validity of a Foreign Language Anxiety Scale". Language Anxiety: From Theory and Research to Classroom Implications. Eds. E.K. Horwitz and D.J. Young. Englewood Cliffs, NJ: Prentice-Hall. 109-126.

[28] Horwitz, E.K.(2010). Foreign and Second Language Anxiety, Language Teaching,43, 154-167.

[29] Hu, G. (2002). Potential cultural resistance to pedagogical imports: The case of communicative language teaching in China. Language Culture and Curriculum, 15(2), 93-105.

[30] Hu, G. (2005). 'CLT is best for China'—an untenable absolutist claim. ELT Journal, 59(1), 65-68.

[31] Jackson, D.N. (1978). Interpreter's guide to the Jackson personality inventory. In P. McReynolds (Ed.), Advances in psychological assessment. San Francisco, California: Jossey- Bass.

[32] Juana, M. \& Palak, D. (2011). Podcasting in a high school Spanish language class to improve the speaking skill: An action research study. Networks, 13(1), 1-18.

[33] Kelly, L. (1982). A Rose by any other name is still a Rose- A Comparative Analysis of Reticence, Communication Apprehension, Unwillingness to Communicate, and Shyness. [Article]. Human Communication Research, 8(2), 99-113.

[34] Khan, Z., \& Zafar, S. (2010). The effects of anxiety on cognitive processing in English language learning. English Language Teaching, 3(2), 199-209. Retrieved from Education Research.

[35] Kitano, K. (2001). Anxiety in the College Japanese Language Classroom. [Article]. Modern Language Journal, 85(4), 549-566.

[36] Kostyuk. N., Meghanathan, N., Isokpehi, R.D., Bell, T., Rajnarayanan, R., Mahecha, O., Cohly, H. (2010). Biometric evaluation of anxiety in learning English as a second language. IJCSNS International Journal of Computer Science and Network Security, 10(1). Retrieved from Education Research Complete database.

[37] Leary, M.R. (1982). Social Anxiety. Review of Personality and Social Psychology 3. Ed. Ladd Wheeler. Beverly Hills: Sage, 1982.

[38] Liu, M. (2006). Anxiety in Chinese EFL students at different proficiency levels. System, 34(3), 301-316.

[39] Liu, M.H., \& Jackson, J.(2008). An exploration of Chinese EFL Learners' unwillingness to communicate and foreign language anxiety. [ Article]. Modern Language Journal, 92(1), 71-86.

[40] Luo, H. (2014). Foreign Language Speaking Anxiety: A Study of Chinese Language Learners. Journal of the National Council of Less Commonly Taught Languages, 15, 99-117. http://www.celea.org.cn/ pastversion/lw/pdf/ZhangXianping.pdf

[41] MacIntyre, P.D. (2007). Willingness to communicate in the second language: Understanding the decision to speak as a volitional process. Modern Language journal, 91(4), 564-576.

[42] MacIntyre, P.D., \& Gardner, R.C. (1991). Language Anxiety. Its Relationship to Other Anxieties and to Processing in Native and Second Languages. [ Articles]. Language Learning, p. 87-92.

[43] MacIntyre, P.D., \& Gardner , R.C. (1991c). Methods and results in the study of anxiety in language learning: A review of the literature. Language Learning, 41,85-117.

[44] Mazouzi, S. (2013). Analysis of Some Factors Affecting Learners' Oral Performance. A Case Study: 3rd Year Pupils of Menaa's Middle Schools. M. A. Dissertation, Department of Foreign Languages, English Division, Faculty of Letters and Languages, Mohamed Khider University of Biskra, People's Democratic Republic of Algeria.

[45] McCroskey, J.C. (1997). Oral Communication Apprehension: A Summary of Recent Theory and Research. Human Communication Research, 4(1), 78-96.

[46] McCroskey, J.C. (1977). Willingness to communicate, communication apprehension, and self- perceived communication competence: Conceptualizations and Perspectives. In D.M. Ayres, J.

[47] Na. Z. (2007). A study of high school students' English learning anxiety. Asian EFL Journal, 9(3), 22-34. Retrieved from Education Research Complete database.

[48] Nakatani,Y. (2010). Identifying strategies that facilitate EFL learners' oral communication: A classroom study using multiple data collection procedures. The Modern Language Journal, 94(1), 346-8512.National Education Association. Retrieved from www.nea.org/home/29914.htm.

[49] Nomass, B. (2013). The impact of using technology in teaching English as a second language. Canadian Center of Science and Education, 3 (1), $111-116$ 
[50] Nunan, D. (2003). The impact of English as a global language on educational policies and practices in the Asia-Pacific region. TESOL Quarterly, 37(4), 589-613.

[51] Ohata, K.(2005) “ Language Anxiety From the Teachers' Perspective: Interviews within Seven Experienced ESL/EFL Teachers', Journal of Language and Learning, vol.3(1), pp.133-155.

[52] Oya, T., Manalo, E., \& Greenwood, J. (2004). The influence of personality and anxiety on the oral performance of Japanese speakers of English. Applied Cognitive Psychology, 18(7), 841-855. doi:10.1002/acp.1063.

[53] Pappamihiel, N. E. (2002). Ambigapathy Pandian (2002). English Language Teaching in Malaysia Today. Asia-Pacific Journal of Education, 22(2), 35-52.

[54] Park, G. \& French, B. (2013). Gender differences in the foreign language classroom anxiety scale. System, 41: 462-471.

[55] Piechurska-Kuciel, E. (2008) Language Anxiety in Secondary Grammar School Student. Uniwersytet Opolski. quantitative and qualitative research. Upper Saddle River, New Jersey.

[56] R. Schwarzer ( 2013). Self-related cognitions in anxiety and motivation. Hillsdale, New Jersey.

[57] Rafada, S. \& Madini, A. (2017). Major causes of Saudi learners' speaking anxiety in EFL classrooms. International Journal of English Language Education, 5 (1), 54-71.

[58] Richards, J. C., \& Rodgers, T. S. (2001). Approaches and methods in language teaching (2nd ed.). Cambridge: Cambridge University Press.

[59] Richards, Jack C. and Theodore Rodgers (2001). Approaches and Methods in Language Teaching. Second Edition. New York: Cambridge University Press.

[60] Savignon, S. J., \& Wang, C. (2003). Communicative language teaching in EFL contexts: Learner attitudes and perceptions. International Review of Applied Linguistics, 41(3), 223-250.

[61] Spielberger (1972) (), Anxiety: Current Trends in Theory and Research. Ed.Academic, (Vol.2). New York: Press,.

[62] Suleimenova, Z. (2013). Speaking Anxiety in a Foreign Language Classroom in Kazakhstan. ProcediaSocial and Behavioral Sciences, 93, 1860-1868.

[63] Suwantarathip, O., \& Wichadee, S. (2010). The Impacts Of Cooperative Learning On Anxiety And Proficiency In An EFL Class. Journal of college teaching \& learning, 7(11), 51-57.

[64] Synder, G.W. (2011). How Anxiety affects Second Language Acquisition of High school students. 1-5. Retrieved from http.//dspace.sunyconnect.sunny.edu/bitstream/handle/1951/58086/Gilbert_Synder_ Masters_Project_December 2011.pdf? Sequence=1.

[65] Von Worde, R. (2003). Students' Perspectives on Foreign Language Anxiety. Inquiry, 8(1), Retrieved from ERIC database.

[66] Weiten, W., \& McCann, D. (2007). Psychology: Themes and Variations. Nelson Publishing Inc. Toronto: ON

[67] Wilson, J.T.S (2006). Anxiety in Learning English as a Foreign Language: It's Associations with students Variables, with overall proficiency and with performance on an oral test. 99-103. Retrieved from http://digibug.ugr.es/bitstream/10481/1074/1/16235290.pdf.

[68] Woodrow, L. (2006). Anxiety and Speaking English as a Second Language. RELC Journal: A Journal of Language Teaching and Research, 37(3), 308- 328. http://rel.sagepub.com/cgi/content/abstract/37/3/308.

[69] Woodrow, L. (2006). Anxiety and speaking English as a second language". RELC Journal, 37(3). DOI: $10.1177 / 0033688206071315$

[70] Wu, K. (2010). The Relationship between Language Learners' Anxiety and Learning Strategy in the CLT Classrooms. International Education Studies, 3(1), 174-191

[71] Yan, X., Horwitz, E.K. (2008). Learners' perceptions of how anxiety interacts with personal and instructional factors to influence their achievement in English: a qualitative analysis of EFL learners in China. Language Learning 58, $151 \mathrm{e} 183$.

[72] Zhang Xianping (2013). Language Anxiety and its Effect on Oral Performance in Classroom. Xiangfan University.

[73] Zheng, Y. (2008). Anxiety and second/foreign language learning revisited. Online Submission.

Citation: Mona Tahseldar. "Could Cll Approach be a Remedy for Tripoli Secondary Students Speaking Skills?."International Journal of Humanities Social Sciences and Education (IJHSSE), vol 5, no. 8, 2018, pp. 129-182. doi: http://dx.doi.org/10.20431/2349-0381.0508015.

Copyright: (c) 2018 Authors. This is an open-access article distributed under the terms of the Creative Commons Attribution License, which permits unrestricted use, distribution, and reproduction in any medium, provided the original author and source are credited. 